\title{
THE EFFECTS OF CELL CYCLE SYNCHRONIZATION ON THE GROWTH POTENTIAL OF PRIMARY ARTICULAR CHONDROCYTES
}

By

Omar Dawood Subedar

BEng. Biomedical Engineering

Ryerson University, 2015

A thesis submitted in partial fulfillment of the requirements

for the degree of Master of Applied Science

in the program of Chemical Engineering

Toronto, Ontario, Canada, 2018

(C) Omar Subedar, 2018 


\section{AUTHOR'S DECLARATION FOR ELECTRONIC SUBMISSION OF A THESIS}

I hereby declare that I am the sole author of this thesis. This is a true copy of the thesis, including any required final revisions, as accepted by my examiners.

I authorize Ryerson University to lend this thesis to other institutions or individuals for the purpose of scholarly research

I further authorize Ryerson University to reproduce this thesis by photocopying or by other means, in total or in part, at the request of other institutions or individuals for the purpose of scholarly research.

I understand that my thesis may be made electronically available to the public. 


\section{Abstract}

The Effects of Cell Cycle Synchronization on the Growth Potential of Primary Articular Chondrocytes Omar Dawood Subedar

Master of Applied Sciences

Chemical Engineering

Ryerson University

2018

Rapid production of cartilaginous extracellular matrix (ECM) is required for scale up of any articular cartilage tissue engineering approach. Although several different methods have been investigated to increase the rate of cartilaginous ECM synthesis (e.g. growth factor stimulation, mechanical loading, etc.), there is evidence to suggest that cell cycle synchronization increases rate of ECM deposition. The issue with primary articular chondrocytes (PACs) is that routine methods to synchronize cells within a particular phase of the cell cycle rely on the use of monolayer culture, which is known to elicit cellular de-differentiation. This required development of a novel method of synchronizing cells within the S phase of the cell cycle during cell isolation. The objective of this study was to test whether synchronizing PACs would improve deposition of cartilaginous ECM in a three-dimensional culture model. Findings suggested that cell cycle synchronization was a viable method of improving the rate of matrix deposition in PACs. 


\section{Acknowledgements}

First and foremost I would like to express my gratitude to my supervisor Dr. Waldman for his continued mentorship and support throughout the course of my thesis. I am grateful for the guidance you offered, through which I was able to learn so much about the research process, but also for the opportunity you afforded me to explore my area of research well outside of the original confines of my project. This stimulated a pressing need for me to answer some of these questions, and above all, a thorough respect for the research process.

Furthermore, I would like to extend my gratitude to my committee members Dr. Doan, Dr. Hwang, and Dr. Olson, for their much appreciated, insightful comments and thought-provoking questions about my research.

I would like to thank Dr. Rita Kandel and Warren Tang for their help in sourcing tissue for experiments, and Chris Spring for his fantastic insight in the field of flow cytometry and cell sorting. To my friends, who I didn't see enough of, cheers for making it phenomenal when I did. I couldn't have asked for better lab mates. From the astute advice to the captivating conversations, I would like to thank you all for making the past three years at St. Michael's Hospital memorable.

To my dearest, thank you for waiting so patiently. Now we have all the time in the world! Mama, Papa, AB, and Sahar- I cannot express my love and appreciation to you enough for supporting me through everything for the past three years.

Finally, I would like to thank God for giving me the strength to see this through. 


\section{Table of Contents}

Abstract

Acknowledgements $\quad$ iv

Table of Contents $\quad$ V

List of Tables viii

List of Figures $\quad$ ix

1. Introduction 1

1.1. Clinical Requirement for Articular Cartilage Tissue 1

1.2. Articular Cartilage Repair Strategies 1

1.3. Cartilage Tissue Engineering 4

1.4. Cell Cycle Synchronization 5

1.5. Research Objectives 5

2. Literature Review $\quad 7$

2.1. Articular Cartilage Tissue 7

2.1.1. Anatomy \& Physiology 7

2.1.1.1. Extracellular Matrix 7

2.1.1.2. Chondrocytes 11

2.1.2. Growth Factors 14

2.2. Articular Cartilage Damage 15

2.3. Cartilage Tissue Engineering 16

$\begin{array}{ll}\text { 2.3.1. Cells } & 16\end{array}$

2.3.2. Scaffolds 17

2.3.3. Signals 19

2.4. Cell Cycle 19

2.4.1. $\mathrm{G}_{0}$ phase 21

2.4.2. $\mathrm{G}_{1}$ phase 22

2.4.3. S phase 22

2.4.4. $\mathrm{G}_{2}$ phase 23

2.4.5. M phase 24

2.4.6. Synchronization 26

2.4.6.1. Characterization 28

3. Methods 30

3.1. Culturing Populations of Synchronized Primary Articular Chondrocytes 30

3.1.1. Articular Cartilage Tissue Harvest $\quad 30$

3.1.2. Synchronization of Tissue In Situ 30

3.1.2.1. Serum Starvation 31

3.1.2.2. Double Thymidine Block $\quad 31$

3.1.2.3. Thymidine-Nocodazole Block 32

3.1.2.4. RO-3306 32 
3.1.2.5. Aphidicolin 32

3.1.2.6. Altered Double Thymidine Block 33

3.2. Hydrogel Immobilization 34

3.2.1. Agarose Cylinders 34

3.2.2. Alginate Cylinders 34

3.2.3. Alginate Beads 35

3.2.4. Recovery 35

3.3. Three-Dimensional Construct Culture 36

3.4. Analysis of Constructs at 2 and 4 Weeks 36

3.4.1. Characterization of Cell Cycle using Flow Cytometry 36

3.4.1.1. Vybrant DyeCycle Ruby 36

3.4.1.2. Propidium Iodide $\quad 37$

3.5. Histological Evaluation 37

3.5.1. Safranin Oxide Staining 38

3.5.2. Sirius Red Staining 38

3.6. Immunohistochemical Evaluation 39

3.6.1. Collagen I and II Staining 39

3.7. Biochemical Evaluation 39

3.7.1. Water content 40

3.7.2. DNA content 40

3.7.3. Hydroxyproline Assay for Collagen Content 40

3.7.4. DMMB Assay for Sulfated GAG Content 41

4. Results 42

4.1. Effect of Synchronizing Treatments on Primary Articular Chondrocytes 42

4.1.1. Viability of Synchronization in Primary Articular Chondrocytes 42

4.1.2. Viability of Encapsulation in Primary Articular Chondrocytes 46

4.1.3. Tracking Cell Cycle Progression of Chondrocytes 46

4.2. Effects of Optimized Synchronization on Chondrogenesis 49

4.2.1. Effect of Optimized Synchronization on DNA Content 49

4.2.2. Effect of Optimized Synchronization on Proteoglycan Content 51

4.2.3. Effect of Optimized Synchronization on Collagen Content 56

5. Discussion 65

5.1. General Discussion 65

5.1.1. Overview of Research 65

5.1.2. Optimizing Synchronization in Primary Articular Chondrocytes 65

5.1.3. Encapsulation for Three-Dimensional Culture and Maintaining Phenotype 66

5.1.4. Effects of Synchronization on Growth of Articular Cartilage Tissue70

5.2. Synchronization Mechanisms and Improved Growth 71

5.2.1. Proliferative Effects of a Cell Cycle Synchronized Population 71

5.2.2. Growth Factor Signaling 73

6. Conclusions

80 
6.1. Conclusions 80

6.1.1. Encapsulation of Primary Articular Chondrocytes 81

6.1.2. Optimizing Synchronization in Primary Articular Chondrocytes 81

6.1.3. Effects of Synchronization on Matrix Synthesis in Long-Term Culture $\quad 82$

6.2. Recommendations 83

6.2.1. Culture System for Synchronized Chondrocytes 83

6.2.2. Utilizing Synchronization to Promote Growth in Human

Chondrocytes $\quad 83$

6.2.3. Mechanisms that Promote Growth in Synchronized Chondrocytes 84

References

85 


\section{List of Tables}

Table 2-1: In vitro cell cycle synchronization agents and respective phase of cell cycle arrest 27

Table 4-1: Viabilities and purities of populations subjected to synchronization techniques

Table 4-2: Characterization of cell cycle phase for control and synchronized groups

Table 4-3: Viabilities of recovered populations subjected to encapsulation techniques

46

Table 4-4: Characterization of cell cycle phase over time 


\section{List of Figures}

Figure 2-1: Characterization of zonal hierarchy within articular cartilage tissue 8 Figure 2-2: Schematic diagram of cell cycle phases and corresponding cyclin expression [126] 21 Figure 2-3: Characterization of the phases of mitosis in a eukaryotic cell [139] 25 Figure 4-1: Representative histograms of the distribution of DNA content 44 Figure 4-2: Representative histograms of the distribution of DNA content of a synchronized group $\begin{array}{ll}\text { measured at } 12 \text { hour intervals } & 47\end{array}$

Figure 4-3: DNA content normalized to control samples at the respective time point 49 Figure 4-4: DNA content normalized to respective two week time point for both sample groups 50 Figure 4-5: Sulfated glycosaminoglycan content normalized to control samples at the respective time point

Figure 4-6: Sulfated glycosaminoglycan content normalized to respective two week time point for both sample groups

Figure 4-7: Ratio of sulfated glycosaminoglycan to DNA content normalized to that of control samples at the respective time point

Figure 4-8: Ratio of sulfated glycosaminoglycan to DNA content normalized to that of respective two week time point for both sample groups

Figure 4-9: Representative staining of matrix synthesis exhibited via Safranin Oxide detection 55

Figure 4-10: Collagen content normalized to control samples at the respective time point 56

Figure 4-11: Collagen content normalized to respective two week time point for both sample groups

Figure 4-12: Ratio of collagen to DNA content normalized to that of control samples at the respective time point

Figure 4-13: Ratio of collagen to DNA content normalized to that of respective two week time points for both sample groups

Figure 4-14: Ratio of collagen to sulfated glycosaminoglycan content normalized to control samples at the respective time point

Figure 4-15: Ratio of collagen to sulfated glycosaminoglycan content normalized to that of respective two week time points for both sample groups

Figure 4-16: Representative staining of matrix synthesis exhibited via Sirius Red detection

Figure 4-17: Representative staining of matrix synthesis exhibited via immunohistochemical staining of Collagen II

Figure 4-18: Representative staining of phenotypic stability exhibited via immunohistochemical staining of Collagen I 


\section{Chapter 1 Introduction}

\subsection{Clinical Requirement for Articular Cartilage Tissue}

Articular cartilage is the tissue that lines joints, easing movement by minimizing friction at the surfaces of adjacent bones. It is characterized by its mechanical properties, low cellular density, and lack of nervous and vascular innervation, resulting in a diminished potential for self-repair [1]. Damage to this tissue can be caused by a range of factors including acute injury and progressive deterioration, leading to pain and swelling of the joint as well as loss of mobility at the articular surface. Osteoarthritis is the major degenerative disease affecting articular cartilage surfaces and their underlying bone [2]. It is characterized by breakdowns at the joint surface leading to a progressive degradation of the articular cartilage layer, causing lesions and wear of the cartilage and inflammation of the adjacent bone tissue [2]. Studies as recent as 2016 report that $23 \%$ of the adult American population (over 54 million people) suffer from this diseased state [3], and in the United States alone, over 500,000 joint restoration or replacement operations are performed every year [4].

\subsection{Articular Cartilage Repair Strategies}

Several repair strategies are currently utilized to tackle the issue of articular cartilage damage by minimizing further degradation and alleviating pain at the joint surface. One such method of restoring mobility in the joint is total joint replacement. This procedure consists of replacement of the defective articular cartilage surface and its subchondral bone with inert materials of similar biomechanical properties to restore mobility of the joint [5]. While completely removing the section of subchondral bone responsible for the pain, it also allows for the restoration of mobility in the joint [5]. Rather than repair the damaged tissue within the body, this technique opts for replacement of the functional materials operating in the joint. The major challenge with this approach is long-term stability of inert materials used for implantation [5].

Chondroplasty is another technique utilized for treatment of articular cartilage degradation. This technique is comprised of first removing any unsecured cartilage flaps at the degraded joint surface, 
followed by smoothing of the remaining degenerative cartilage to stabilize the joint around the chondral lesion [6]. Debridement of the degraded tissue is done using an oscillating surgical shaver [6]. Because of the requirement of a smooth articulating surface in functional tissue, this procedure is frequently performed in tandem with other surgical interventions [6]. While this is a particularly effective palliative measure in the joint, it is an invasive procedure that does nothing to repair or restore mobility in the joint [6]. A more restorative procedure is required to significantly improve patient quality of life.

One temporary method of treatment is viscosupplementation, a procedure involving the injection of lubricating fluid into the joint to reduce swelling and minimize joint pain [7]. The lubricating fluid is comprised of hyaluronic acid and other extracellular matrix macromolecules that are secreted by chondrocytes and thus commonly found in articular cartilage tissue [7]. An additional function of these macromolecules is the inhibition of catabolic pathways triggered by cytokines in osteoarthritic joints [7]. While this method is frequently employed to alleviate the symptoms associated with the diseased state, it does nothing to repair full thickness lesions that result from the progressive degradation of the tissue in this diseased state. Consequently, the occurrence of secondary procedures is common when employing this technique [7].

Another method used to treat smaller lesions at the joint surface is microfracture surgery. This procedure is comprised of chondroplasty to debride any degraded cartilage at the joint surface [8]. Following this, small lesions are made at the surface of the subchondral bone, allowing for cells from the bone marrow to populate the joint surface and create a blood clot at the site of the defect [8]. This results in the recruitment of mesenchymal stem cells from the bone marrow with the capacity to heal the chondral defect with fibrocartilaginous scar tissue [8]. While the fibrocartilaginous layer does not repair the function of articulating the surface of the joint as well as a layer of smooth, lubricated articular cartilage, it does alleviate some of the pain associated with otherwise exposed subchondral bone [8].

The use of cell therapies to repair the function of the joint represents a more elegant solution to articular cartilage damage. One such method of repair is osteochondral tissue transfer, wherein a section of donor articular cartilage tissue and its subchondral bone are carefully shaped to fit the lesion site and 
grafted on to heal with the surrounding bone and cartilage tissue $[9,10]$. The forces applied to the tissue and its constituent cells must remain below a certain threshold during the surgery or the viability drops and the success of the operation decreases accordingly [9]. In addition, the risk of reoperation is high when patients undergo such procedures [9].

Recent strategies in repair aim to deal with damage to articular cartilage tissue by Autologous Chondrocyte Implantation (ACI). This involves in vitro expansion of autologous cells that are enzymatically isolated from their collagen matrix to implant at the site of lesions in order to resurface the subchondral bone [11]. ACI is the idealized solution for defects in articular cartilage as it harnesses the potential of the patient's cells to create articular cartilage tissue for implantation at the site of the defect, preventing further swelling and damage to the subchondral bone [11]. It involves an initial biopsy of articular cartilage tissue from a non-load bearing portion of the joint, from which chondrocytes are enzymatically isolated and expanded in sterile monolayer culture in flasks, followed by implantation of these cells to synthesize cartilaginous matrix at the site of the defect [11]. Occurrence of re-operation in this method of treatment is comparatively lower than traditional approaches [12].

A further progression of the ACI treatment mode is Matrix-Induced Autologous Chondrocyte Implantation (mACI), which has the additional step of seeding the expanded cell populations on biocompatible, three-dimensional matrices before implantation, followed by attachment of the graft at the site of the lesion with fibrin glue [13]. Long-term assessments of attachment and function of embedded tissue after implantation have demonstrated the reparative function of this technique as sustainable over a period of several years post-operation [14]. However, it requires additional time to generate tissue of appropriate scale for implantation [13].

These techniques have been established and widely utilized to treat damage at the articulating surface. While the benefits of each method are clear, many of these procedures are found lacking in terms of their ability to alleviate pain, repair damaged tissue, or restore joint function. Several of these techniques do nothing to address the hampered mobility associated with degraded cartilage, and represent short-term solutions to the issue with little guarantee of long-term stability or solution to the underlying 
cause of the defects. The drawbacks associated with these techniques often lead to the requirement for secondary procedures, adding to the cost and time required for therapeutic treatment, opening up a need for a more innovative solution.

\subsection{Cartilage Tissue Engineering}

Tissue engineering is a field of research with the objective of generating replacement tissue for implantation within the body. Its focus is the utilization of cells, scaffolds, and signaling molecules, often in tandem, to produce tissue constructs for the medical repair or replacement of a specific biological tissue [15]. These tissue constructs are commonly fabricated in vitro followed by either an expansion period in culture or in vivo implantation at the site of the defect [15]. Approaches that utilize the implantation of the patient's own cells (termed autografts [9]) are the ideal. The primary issue with these techniques is that their efficacy remains high only in younger patients with single lesions of smaller area at the articular cartilage surface [3]. The regenerative capability of cells is limited in older individuals and patients of osteoarthritis, wherein the cells responsible for cartilage maintenance are at an imbalance in terms of biosynthesis of new extracellular matrix and enzymatic digestion of damaged extracellular matrix [3]. In such cases, implants generated from another individual of the same species (termed allografts [10]) are utilized. Alternatively methods of stimulating the patient's own cells are required for production of a tissue engineered implant. Growth factor stimulation, media formulation, and altered culture conditions are all approaches that have been attempted to generate more robust tissue at an accelerated rate [2]. Utilizing the principles of tissue engineering, several approaches have been developed to repair articular cartilage damage. The challenge with tissue engineering is in the amount of time it takes to scale up tissue to an appreciable grade for implantation, since engineered tissue frequently fails to replicate the ideal mechanical properties exhibited in native articular tissue. Though scale up is a challenge, stimulating proliferation is a requirement since a population of 15-20 million chondrocytes is required for implantation at a single defect site [16]. This represents a significant hurdle in the overall time required for this procedure, giving rise to the requirement for a method of improving the rate of 
proliferation and tissue growth. In examining the cell cycle, the process by which cells proliferate, some of the mechanisms by which this growth improvement occurs could be elucidated.

\subsection{Cell Cycle Synchronization}

The cell cycle is the set of sequential phases through which a cell divides to produce two daughter cells. It consists of four major phases in which the major cellular constituents are replicated and verified ahead of physical division into a pair of genetically identical daughter cells [17]. Continuous progression through the cell cycle is mandatory for the several population doublings required for development of abundant cell populations and the ensuing tissues they form. The precise involvement of the specific cell cycle activity in growth of primary articular chondrocytes remains uninvestigated. Furthermore, there is data to suggest that chondrocyte progenitor stem cells (specifically mesenchymal stem cells, or MSCs) that are synchronously progressing through the cell cycle accumulate more synthesized matrix when cultured in vitro [18]. The use of chondrocyte progenitor cells in the previous study likely has to do with their potential as stem cells for undergoing significant population growth. This raises the question of whether primary articular chondrocytes can be stimulated to scale up tissue production in a similar manner through synchronization.

\subsection{Research Objectives}

The primary objective of this research was to ascertain the effects of cell cycle synchronization on the ability of primary articular chondrocytes to synthesize articular cartilage tissue. While synchronization of mesenchymal stem cells being differentiated down chondrogenic pathways has been demonstrated to enhance their growth potential, the growth characteristics of primary articular chondrocytes undergoing similar stimulation has not been explored. Synchronization of cells in monolayer in vitro culture has previously been investigated utilizing an array of known cell cycle synchronization agents [19]. Traditional methods of synchronization are thus optimized for monolayer culture and unsuitable for articular cartilage explant culture, since monolayer culture elicits dedifferentiation of primary articular chondrocytes to a fibroblast-like phenotype [20]. This is a significant 
drawback to this method as it would require additional time to re-differentiate the cells before they produce the appropriate tissue for implantation. A revised synchronization protocol for the specific cell line in use was developed in order to ensure successful synchronization before conducting further analysis on control and synchronized populations. 


\section{Chapter 2 Literature Review}

\subsection{Articular Cartilage Tissue}

Articular cartilage is the resilient white layer that coats bone tissue at articulating joint surfaces to provide lubrication and load-bearing capability [21]. It is responsible for the low friction and wear characteristics in joints that enable repeated gliding motion of adjacent bones [22]. Synovial fluid

lubricates the joint surface and acts as a nutrient source, facilitating nutrient uptake by pressure gradients that allow small molecules to traverse from the underlying bone and synovial fluid into the avascular tissue [23]. In most healthy synovial joints, articular cartilage tissue can allow for smooth motion of adjacent bones for over 80 years [24].

\subsubsection{Anatomy and Physiology}

Articular cartilage tissue is largely comprised of extracellular matrix (ECM), with a scarce, heterogeneous distribution of differentiated cells, known as chondrocytes, in the tissue [25]. The primary constituent structural molecules of the ECM are water, proteoglycans, and collagens, with other proteins, lipids, phospholipids and glycoproteins comprising a significantly smaller percentage of the tissue mass [21]. The ECM is synthesized and maintained by the resident chondrocyte phenotype, and provides the tissue with its mechanical properties as well as acting as a substrate for cell signaling [25]. The primary constituent molecules in the ECM are responsible for the characteristic structural and mechanical properties of the tissue that make it well suited to its function within the body [1].

\subsubsection{Extracellular Matrix}

Structurally, articular cartilage tissue varies with respect to its depth [21]. This is due in large part to the changes in composition of the tissue, which can be characterized by four distinct zones: superficial, transitional, deep, and calcified cartilage [21]. The orientation of chondrocytes and collagen fibrils are shown below in Figure 2-1A and 2-1B respectively [1]. Specifically, differences in the shape 
and population density of chondrocytes, diameter and organization of collagen fibrils, concentration of proteoglycans, and volume of water are key factors used to distinguish zonal hierarchy.

The superficial zone is the furthest from subchondral bone, providing the articular surface along which gliding motion is facilitated [26]. It is comprised of thin collagen fibrils and flattened chondrocytes, which are both arranged parallel to the articular surface [26]. Water content is highest in this zone of the tissue [26]. The transitional zone, also known as the middle zone, is situated beneath the superficial zone, comprising approximately half of the tissue volume [26]. It is characterized by rounded chondrocytes with more spatial separation, and larger collagen fibrils in terms of diameter that exhibit less organization with respect to orientation [26]. The deep zone contains the highest cell density, with considerably higher proteoglycan concentration around the chondrocytes [26]. Spherical chondrocytes in this zone are arranged in columns perpendicular to the articular surface, and water content is lowest in this zone [26]. The calcified cartilage layer lies between the deep zone and the subchondral bone, and is comprised of small cells in a cartilaginous matrix that is encrusted with phosphate rich minerals such as hydroxyapatite [26].

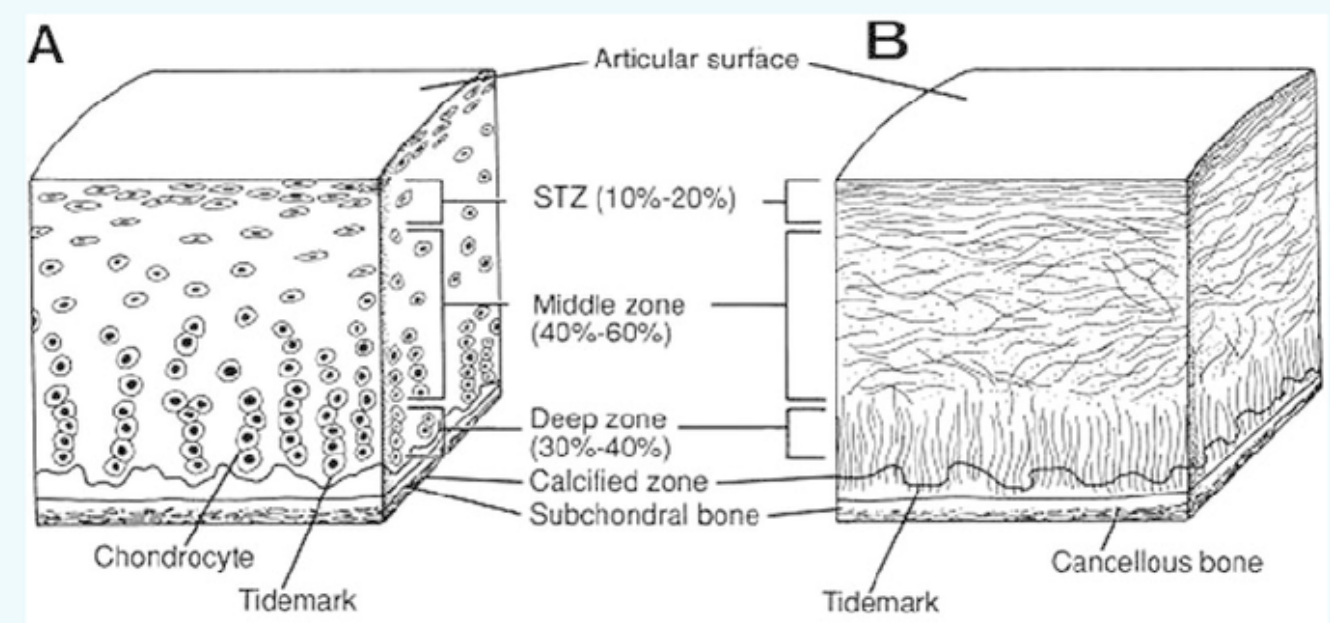

Figure 2-1: A) Schematic of zonal arrangement of chondrocytes within articular cartilage tissue B) Schematic diagram of zonal arrangement of collagen within articular cartilage tissue [1].

The ECM can be further characterized in terms of proximity to chondrocytes, the resident cell phenotype found in articular cartilage. The region immediately adjacent to the cell membrane is referred 
to as the pericellular matrix, comprised mostly of proteoglycans with virtually no collagen fibrils present [27]. The term chondron is used to describe an articular chondrocyte and its pericellular matrix [27]. Extending out from the pericellular matrix is the territorial matrix, which contains thin collagen fibrils on its periphery that create the fibrillar network, defining the border between the territorial and interterritorial matrix [28]. The most distant regions from chondrocytes are termed the inter-territorial matrix which comprises the largest of these ECM classifications, having the most significant effect on the mechanical properties of the tissue [29]. It is characterized by presence of large collagen fibers and contains the bulk of the proteoglycan content found in the tissue [29].

\section{Water Content}

Water comprises between $65-80 \%$ of the wet weight of articular cartilage, making it the most abundant molecule in the tissue [30]. Water concentration varies with respect to the depth of the tissue, with a significantly higher concentration at the articular surface that progressively decreases [31]. Water traverses the tissue through pressure gradients generated by physical compression of the solid ECM [30]. However, the pore size of approximately $6 \mathrm{~nm}$ in the ECM results in a high frictional resistance to flow, significantly reducing the permeability of the tissue [50]. The superior mechanical stability in supporting high load in the joints arises as a result of the frictional resistance and pressurization of water in the ECM [30]. Flow of water through the tissue also aids in transport of nutrients to the cells and lubrication of the joint surface [31]. While some water retention in the tissue can be attributed to capillary action on the surface of collagen fibrils, this effect is a considerably weak force [31]. High affinity for water in the tissue stems from the abundance of hydrophilic proteoglycans, which attract interstitial ions and increase their volume in solution [31].

\section{Proteoglycan Content}

Proteoglycans (PGs) are abundant macromolecules in articular cartilage tissue [32]. They consist of a protein core that is covalently bound to polysaccharide chains, named glycosaminoglycans (GAGs) [32]. GAGs are comprised of long, unbranched chains of repeating disaccharide units with 
repeating sulfate $\left(\mathrm{SO}_{4}\right)$ or carboxyl $(\mathrm{COOH})$ groups [33]. In solution, these groups ionize to form $\mathrm{SO}_{3}{ }^{-}$ and $\mathrm{COO}^{-}$respectively, which require cations to balance the net charge in the tissue [33]. These cations, which are found in interstitial water in the tissue, bind to the negatively charged groups. The three most common glycosaminoglycan chains found in the PGs of articular cartilage are chondroitin sulfate, keratan sulfate, and dermatan sulfate [33]. Chondroitin sulfate is the most common chain in articular cartilage tissue, accounting for up to $90 \%$ of the total population (depending on age or presence of diseased state) [33]. Two common isomers exist for these chains (chondroitin 4-sulfate and chondroitin 6 sulfate), which consist of between 25 and 30 consecutive disaccharide units [33]. The average molecular weight of a chondroitin sulfate chain is between 15 and $20 \mathrm{kDa}$ [33]. In healthy young tissue, chondroitin 4-sulfate is the most prevalent form while keratan sulfate expression is relatively low [34]. Concentration of keratan sulfate increases with age, and chondroitin 6-sulfate becomes the prevalent form in the tissue [34]. Keratan sulfate chains are relatively smaller, with molecular weights of between 5 and $10 \mathrm{kDa}$ [33]. Hyaluronate is a GAG chain that lacks sulfation [33]. Unlike sulfated GAG chains, hyaluronate lacks a protein core, and is present as an unbranched GAG chain in the tissue, with large molecular weight (exceeding $\left.10^{6} \mathrm{kDa}\right)[33]$.

Between $80-90 \%$ of the proteoglycans found in articular cartilage tissue are known as aggrecans for their large size resulting from aggregation [35]. These aggrecans are comprised of a long protein core that is covalently bound to several GAG chains (up to 100 chondroitin sulfate chains and up to 50 keratan sulfate chains) [35]. These molecules aggregate through interactions between domains of the aggrecans and hyaluronates, which are further strengthened by binding of link proteins at both sites [35]. Long, unbranched hyaluronan chains can bind several aggrecans to produce large proteoglycan aggregates that are more stable within the ECM [35]. Hyaluronan chains bound to over 300 aggrecan molecules can be found in fetal cartilage, but the number of bound aggrecans on a hyaluronan chain decreases significantly with age and presence of diseased state [36]. The interactions of these proteoglycans with collagen fibrils provide articular cartilage tissue with its unique mechanical properties to bear compressive loads [32]. 


\section{Collagen Content}

Collagens are a family of abundant polypeptides that provide structural stability to the articular cartilage tissue [1]. They comprise over $50 \%$ of the dry weight of articular cartilage tissue [37]. The defining characteristic of these proteins is the triple-helical structure, composed of 3 polypeptide $\alpha$-chains of a repeating amino acid sequence of glycine and two other amino acids (most commonly proline and hydroxyproline) [38]. The winding of the three amino acid chains about each other is strengthened through hydrogen bonding [38]. The most prevalent form of chondrocyte-synthesized collagen is type II, which represents $90-95 \%$ of the collagen in the tissue [37]. Cartilaginous ECM also contains type V, VI, IX, X, and XI collagen [38]. Type I collagen is localized to the calcified regions in cartilage, and is also found in bone tissue [37]. It is suggested to play a role in the mineralization of the calcified cartilage region that rests above subchondral bone [38].

Fibers of type II collagen are relatively thinner, which is an alteration that allows them to interact with more proteoglycans in the tissue [38]. Width of the fibers ranges from 10-100 nm, and there is evidence to suggest width increases with age or disease [39]. Organization of the fibers varies greatly with respect to the zone in which they are present, which is responsible for the tensile strength of the tissue [26]. The cross-linkage of collagen fibrils to themselves as well as other collagen fibrils strengthens the stability of the network in the ECM, improving the tensile strength of the tissue [38]. Formation of this strong, cross-linked network in articular cartilage reportedly takes several weeks [37]. Proteoglycan aggregates that retain water and swell in the ECM and a strong collagen fibril network to constrain them are the two primary contributors to the exceptional tensile and compressive strength of articular cartilage tissue [1].

\subsubsection{Chondrocytes}

Chondrocytes are the resident cell phenotype found in articular cartilage, responsible for its synthesis and maintenance $[1,25,26]$. In tissue of skeletally mature individuals, these cells comprise less than $10 \%$ of the tissue volume [25]. They are derived from mesenchymal lineage, with populations of 
mesenchymal stem cells (MSCs) differentiating from the bone marrow during skeletal morphogenesis [39]. Chondrocytes are metabolically active cells, evidenced by their ability to synthesize a vast array of structural molecules and degradative enzymes that are critical to the ECM [39]. Common indicators of the chondrocyte phenotype include gene expression, with SOX-9 and COL2A1 representing two of the most frequently transcribed genes in differentiated chondrocytes $[40,41]$. The COL2A1 gene codes for transcription of the $\alpha$-chain polypeptide of type II collagen, while the SOX-9 transcription factor is an upstream regulator of several processes associated with chondrogenic differentiation and cartilage formation $[40,41]$. Investigation of cell surface markers has not yielded any conclusive evidence of chondrocyte-specific surface receptors [42].

Chondrocytes are responsible for the production and distribution of cartilaginous matrix components in articular cartilage [43]. The anabolic pathways through which proteins, phospholipids, glycosaminoglycans, and glycoproteins are synthesized by chondrocytes are complex and diverse [44]. These macromolecules are also incorporated into the ECM by chondrocyte action [1]. Maintenance of healthy articular cartilage tissue is dependent upon the successful activity of chondrocytes in balancing rates of macromolecule synthesis, incorporation, and degradation, which are all regulated by a variety of environmental factors and signals [45]. Altered response of chondrocytes to environmental stimuli can result in changes to composition and organization of the ECM, and ultimately cartilage degeneration [45].

Anabolic pathways in chondrocytes are responsible for the synthesis and assembly of the prolific proteoglycan macromolecules and collagen polypeptides that make up the majority of the cartilaginous ECM [51]. Transcription of messenger RNA (mRNA) of the appropriate DNA sequence in the nucleus begins through increased expression of the corresponding genes for the secretory proteins being synthesized (either the protein core of a proteoglycan or the $\alpha$-chain of a collagen fibril) [52, 53]. These polypeptides are synthesized at the ribosome of the cell before further assembly of the molecules is completed $[52,53]$. In the case of proteoglycans, the protein core is transported to the Golgi complex where it is conjugated with GAG chains [52]. In the case of collagens, the newly formed polypeptide $\alpha$ - 
chains are extruded into the rough endoplasmic reticulum, where the chains undergo glycosylation and hydroxylation leading to the formation of the triple helix [53]. The hydroxylation of proline and lysine requires the presence of vitamin $\mathrm{C}$ as a cofactor [53]. Once secreted, collagen molecules assemble themselves into a fibrillar array to ease the process of covalent cross-link formation [53]. The rate at which these cartilaginous macromolecules are synthesized dictates the growth of the tissue, and can be influenced by stimuli including injury, osteoarthritis, pressure changes, serum levels, stresses and strains, calcium concentration, $\mathrm{pH}$ fluctuation, and presence of growth factors [1].

Catabolic pathways of chondrocyte metabolism are common in the regular function of the tissue as remodeling occurs in the ECM [61]. However, injury and presence of disease can accelerate this rate of degradation such that it is at an imbalance with the synthesis of new ECM proteins [62, 63]. Breakdown of proteoglycans in the tissue is attributed to enzymatic degradation of the protein core of the molecule, enabling the portion bound to the GAG chains to traverse the ECM and exit the tissue [64]. This portion passes from synovial fluid to the synovium and enters the lymphatic system for removal from the body [64]. Quantifying the proteoglycan fragments is a useful measure of the catabolic activity, which is a promising diagnostic evaluation in terms of presence of disease in the joint [64]. The specific mechanisms through which collagen catabolism occur in articular cartilage are postulated to be enzymatic, with the demonstration of metalloproteinases such as collagenase that are capable of cleaving the triple helix characteristic of collagen fibrils [65]. Though the rate of collagen catabolism is low in healthy tissue, it is observed to increase during remodeling that occurs during skeletal growth as well as in degenerative cartilage tissue [66].

Catabolism in articular cartilage occurs during normal tissue turnover, and degradation occurs as a result of the activity of proteolytic enzymes secreted by chondrocytes [61]. Consequently, chondrocytes are responsible for the synthesis, maintenance, and breakdown of macromolecules that make up cartilaginous ECM. A family of enzymes known as cathepsins are capable of breaking down aggrecan in articular cartilage tissue [67]. These enzymes operate under acidic conditions (pH 5 or lower), and are expected to have a lesser role in proteoglycan degradation [67]. While metalloproteinases such as 
collagenase are the only molecules in the tissue known to cleave the triple helix structure of a collagen fibril, they have also been shown to further degrade collagen and proteoglycans in the tissue $[68,69,70]$. Stromelysin is also identified in the breakdown of aggrecan through cleavage of the protein core along with another as yet undescribed proteolytic enzyme [71]. These metalloproteinases are named for their activity in the presence of zinc at the active site of catabolism [72].

Regulation of degradative enzymes occurs through activation and inhibition [72].

Metalloproteinases described above are latent enzymes that require further activation outside of the cell after being synthesized [72]. Their active forms are inhibited by a molecule named tissue inhibitor of metalloproteinase (TIMP), which is synthesized in response to TGF- $\beta$ signaling $[73,74]$. Control of cathepsins occurs through $\mathrm{pH}$ regulation in the tissue [67]. While the requirement of acidic conditions would inhibit the effects of these degradative enzymes in normal cartilage tissue, it has been observed that the low $\mathrm{pH}$ at which they optimally degrade proteoglycans can be achieved in the chondrocyte pericellular matrix, meaning it cannot be ruled out as a significant enzyme in cartilage catabolism [75].

\subsubsection{Growth Factors}

Synthesis of both proteoglycans and collagens has been demonstrated to be altered by several endogenous and exogenous environmental growth factors in articular cartilage tissue $[54,55,56]$. Comprehensive explanations of the pathways of these growth factors have not all been described but the actions of most have been observed to occur through cell surface receptor sites or soluble signals $[55,56]$. Response to most of these signals is highly specific, with local concentration of the growth factor and number of appropriate cell surface receptors dictating the degree of response [55]. Examples of growth factors that alter metabolism of articular chondrocytes include fibroblast growth factor (FGF), connective tissue growth factor (CTGF), insulin-like growth factor-I (IGF-I), platelet derived growth factor (PDGF), and transforming growth factor beta (TGF- $\beta$ ) [56]. Many of these growth factors are also known to elicit proliferation and cell cycle progression [57-60]. 


\subsection{Articular Cartilage Damage}

Damage to articular cartilage tissue can lead to deterioration or loss of function that consequently affects subchondral bone, often leading to injury [76]. Gliding of adjacent bones that are not protected with the healthy layer of articular cartilage tissue can result in pain, inflammation, and osteophyte formation [77, 78]. It can also result in increased risk of fracture of the subchondral bone [79]. This damage can occur as a result of articular surface lesions through traumatic injury, progressive degradation with age, or presence of a diseased state such as osteoarthritis $(\mathrm{OA})[79,80]$.

Changes occur on a biochemical level in terms of the structural macromolecules that comprise the tissue [81-83]. Advanced stages of OA as well as general tissue degeneration are both associated with a decrease in DNA content (a measure of cellularity) in affected regions of the articular cartilage [83]. Water content is observed to increase slightly in OA patients, affecting structure of the collagen fibril network-restrained proteoglycans in the ECM [82-83]. Proteoglycan content is reduced in advanced stage OA patients, with significantly decreased levels of aggregation, suggesting increased activity of the proteolytic enzymes $[82,83]$. No significant change to the concentration of collagen has been observed in OA patients, but degree of collagen organization is demonstrated to decrease considerably, resulting in loss of the tensile strength of the tissue $[82,83]$.

Altered metabolism in articular cartilage tissue leads to changes in synthesis/degradation rates, which result in biochemical changes $[84,86]$. Though the rate of proteoglycan synthesis is observed to increase in $\mathrm{OA}$, the overall concentration of proteoglycans in the tissue decreases, meaning the rate of proteoglycan catabolism significantly increases with diseased state [84, 85]. The synthesis of collagen appears to increase with OA, though incorporation into a collagen fibril network in the ECM is not always maintained [85]. Furthermore, large-scale degradation of collagen in OA does not become apparent until the final phase of cartilage degeneration [85]. The proper maintenance of the tissue relies on balance between the anabolic and catabolic processes, and imbalance of this metabolism results in cartilage degeneration $[84,86]$. 


\subsection{Cartilage Tissue Engineering}

Tissue engineering is an interdisciplinary field involving incorporation of cells, biomaterial scaffolds, and environmental/biochemical signals to develop substitute tissues with the objective of repairing, maintaining, or improving the function of damaged or diseased tissues within the body [87]. The need for cartilage tissue engineering stems from degeneration that frequently occurs due to sports injuries, increasing age, and diseased states such as osteoarthritis [88, 89]. Defects in cartilage tissue require innovative repair techniques due to the lack of ability for self-repair, stemming from the avascular nature of the tissue [23]. The idealized approach is an implant of autologous tissue from a donor site to the defect site, but sourcing a population of cells large enough to repair the defect site represents a challenge that tissue engineering methodologies aim to rectify [90]. A perfect solution repairs the tissue to full load-bearing function without the requirement of additional procedures [87].

\subsubsection{Cells}

Cells are the smallest unit of life capable of reproduction [91]. This unique capability makes them the starting point for all tissue engineering strategies [92]. In the case of cartilage tissue engineering, mesenchymal stem cells are often used as a source population because of their inherent ability to expand in monolayer culture [92]. However, these cells require differentiation to begin producing the cartilaginous ECM required for implantation at the defect site $[93,94]$. Thus, chondrocytes are often harvested from non-load bearing donor sites on the patient and utilized to create engineered cartilage for implantation [95]. The rationale in using chondrocytes primarily lies with their ability to begin synthesizing matrix more quickly given the appropriate culture conditions [95]. 


\subsubsection{Scaffolds}

Scaffolds are substrates upon which cells can be cultured in vitro to promote proliferation or differentiation [96]. They are ideally biocompatible materials that mimic the material properties of the healthy tissue $[96,97]$. In the case of cartilage tissue engineering, hydrogel scaffolds are utilized for their ability to immobilize the cells while providing appropriate mechanical properties to allow for continued expansion of the cells in vitro ahead of implantation [98].

Many encapsulating materials are utilized to culture cells in vitro for interactions and effects on different cell phenotypes [99]. Immobilizing chondrocytes in 3D hydrogels works to keep the cells differentiated [100]. Hydrogels are polymerizing, hydrophilic materials that form three-dimensional networks [101]. Their hydrophilic nature allows for uptake of water and other biological fluids such as synovium or culture media [101]. Hydrogels can be polymerized under conditions that provide them with mechanical properties similar to articular cartilage tissue while allowing for improved levels of diffusion to ensure encapsulated cells receive appropriate nutrition required for their metabolic activity [101, 102].

\section{Agarose}

Agarose is a polysaccharide chain which makes up half of the molecule known as agar that is commonly used as a substrate for culture of cells in vitro [103]. Agarose chains contain D-galactose units that alternate with more structurally complex saccharide units linked by glycosidic bonding [104]. These chains form helical coils that aggregate tightly about each other with radii between 20-30 nm [104]. Agarose can be chemically manipulated through a process called hydroxyethylation to reduce a strands degree of hydrogen bonding with respect to itself [104]. The polymerized three-dimensional structure that agarose forms is secured through hydrogen bonding, meaning heat is required to break the bonds and return the gelled mass to liquid state [104]. Hydroxyethylation reduces the melting point of agarose [105]. $1-2 \% \mathrm{w} / \mathrm{v}$ agarose hydrogels are used for chondrocyte encapsulation as this concentration provides embedded chondrocytes with a mechanical environment similar to that of native articular cartilage tissue [106-108]. 


\section{Alginate}

Alginic acid, also referred to as alginate, is a polysaccharide that polymerizes by cross-linking itself in the presence of divalent cations such as calcium or magnesium ions [109]. It is generally classified as containing more $\mathrm{G}$ residues (termed $\mathrm{G}$ block) or $\mathrm{M}$ residues (termed $\mathrm{M}$ block), and characterization of cross-linkage depends on the presence of more of one specific residue [110]. Alginate is useful in tissue engineering applications as a naturally occurring polymer hydrogel scaffold that retains water and allows for diffusion through its semi-permeable membrane without restricting cellular function and metabolism [111]. Through polymerization of alginate beads in the presence of calcium ions in solution, populations of cells embedded within the alginate mixture can be cultured in vitro in threedimensional scaffolds without the presence of any toxicity-eliciting chemicals [111]. Typically, a $0.5-2 \%$ $\mathrm{w} / \mathrm{v}$ final alginate concentration is employed for in vitro 3-D culture [112-114]. Alginate is biodegradable [109], making it suitable for implantation such that the degradation of the alginate scaffold can be optimized to coincide with the formation of cartilaginous ECM.

\section{Matrix Macromolecules}

Collagen, chondroitin sulfate, and hyaluronic acid are all commonly expressed in cartilaginous ECM $[21,33,35]$. Composite hydrogels generated from polymerized mixtures of these macromolecules closely resemble in vivo conditions, making these materials suitable scaffolds for encapsulation and tissue engineering applications [115]. Though type II collagen would be the logical choice due to its profuse expression in articular cartilage tissue, hydrogels often incorporate a mixture of type I collagen and type II collagen to improve the mechanical properties of the scaffold to a level similar to that of native articular cartilage tissue $[116,117]$. Hyaluronan is the primary constituent in the hydrogel, utilized for its superior characteristics as a biodegradable, biocompatible substrate that elicits no immune response [115-118]. Composite materials of hyaluronan and collagen have been utilized for culture of chondrocytes and chondroprogenitor cells at different concentrations, with significant variability in the amounts of collagen and hyaluronan utilized to fabricate scaffolds [118]. 


\subsubsection{Signals}

Signaling molecules play a critical role in tissue engineering as they are capable of stimulating growth and differentiation [119]. The mechanical and chemical environment in which the cells are cultured elicit effects on the expression of the cells $[119,120]$. In addition, cues from the environment biochemical environment arise in the form of signaling growth factors, the concentration of which can have significant impact on the proliferation and matrix synthesis of articular chondrocytes [119, 54-60]. In the case of tissue engineering, utilization of appropriate signaling stimuli can be harnessed to differentiate mesenchymal stem cells or accelerate the rate of matrix macromolecule deposition [119121]. Several growth factors, cytokines, and physiochemical factors have been observed to drive chondrogenic differentiation and metabolism [121].

\subsection{Cell Cycle}

The cell cycle is the complex set of regulatory processes by which a cell replicates its contents, terminating after mitosis which produces two daughter cells. Controlled progression through the cell cycle is required for the division of cells and, by extension, the proliferation of populations [126]. The critical processes in the cell cycle are cell growth, replication of genetic material, verification and distribution of the replicated genetic material to daughter cells, and cell division [126]. Fundamental molecules in the regulation of these processes are a family of proteins called cyclins, as well as an associated family of coupling proteins named cyclin dependent kinases (cdks) [126-128]. These two families of proteins are intricately linked to the transcription of certain differentially expressed factors that allow for progression through the cell cycle $[127,128]$. The average length of a eukaryotic cell cycle is approximately 24 hours based on culture of a variety of lineages of human cells in vitro [129]. A study of murine growth plate chondrocytes estimated the total cell cycle duration at 30.9 hours [130].

While progression through the cell cycle is facilitated by regulation of the transcription of cyclins and cdks, division of cells is not always required and must be regulated within the body $[127,128,146$, $150,154]$. Several inhibitory molecules are secreted by cells to act in this capacity, preventing unwanted 
proliferation by inhibiting progression past the checkpoint gap phases through active downregulation of cyclins and cdks $[146,150,154,172-176]$. Expression of cell cycle inhibitory proteins is limited or nonexistent in early embryonic cells, which instead skip the $G_{1}$ and $G_{2}$ phases and cycle between DNA synthesis and mitosis with total cycling time taking approximately 30 minutes or less [177-179]. In this scenario, early embryonic cells do not grow after mitosis, and consequently become smaller and smaller with each successive division [180]. Based on this embryonic model, it is assumed the majority of the growth of eukaryotic cells occurs within the $\mathrm{G}_{1}$ and $\mathrm{G}_{2}$ checkpoint phases between DNA synthesis and mitosis $[126,147]$.

Certain processes that are carried out during the cell cycle can be grouped together into a specific sequence of related events, termed phases. Generally, the cell cycle can be broken down into two overarching aspects: mitosis and interphase [131]. Mitosis comprises the separation of daughter chromosomes into two sets followed by physical division into two daughter cells (termed cytokinesis) [131-132]. Interphase is characterized as the period of time that a cell spends between mitoses, in which decondensation, replication, and distribution of the chromosomes occur [131-134]. Cell growth during interphase is consistent, and the size of the dividing cell generally doubles between consecutive mitoses [132]. Each diploid (2n) cell contains two full sets of chromosomes that comprise the genetic material contained within the nucleus of a cell [133]. Replication of the deoxyribonucleic acid (DNA), which forms the chromosomes, is limited to a distinct portion of interphase, thus leading to a classification of four distinct cell cycle phases of division $\left(\mathrm{M}, \mathrm{G}_{1}, \mathrm{~S}\right.$, and $\left.\mathrm{G}_{2},\right)$ [126]. These phases and their corresponding cyclin protein expression are shown in Figure 2-2. 


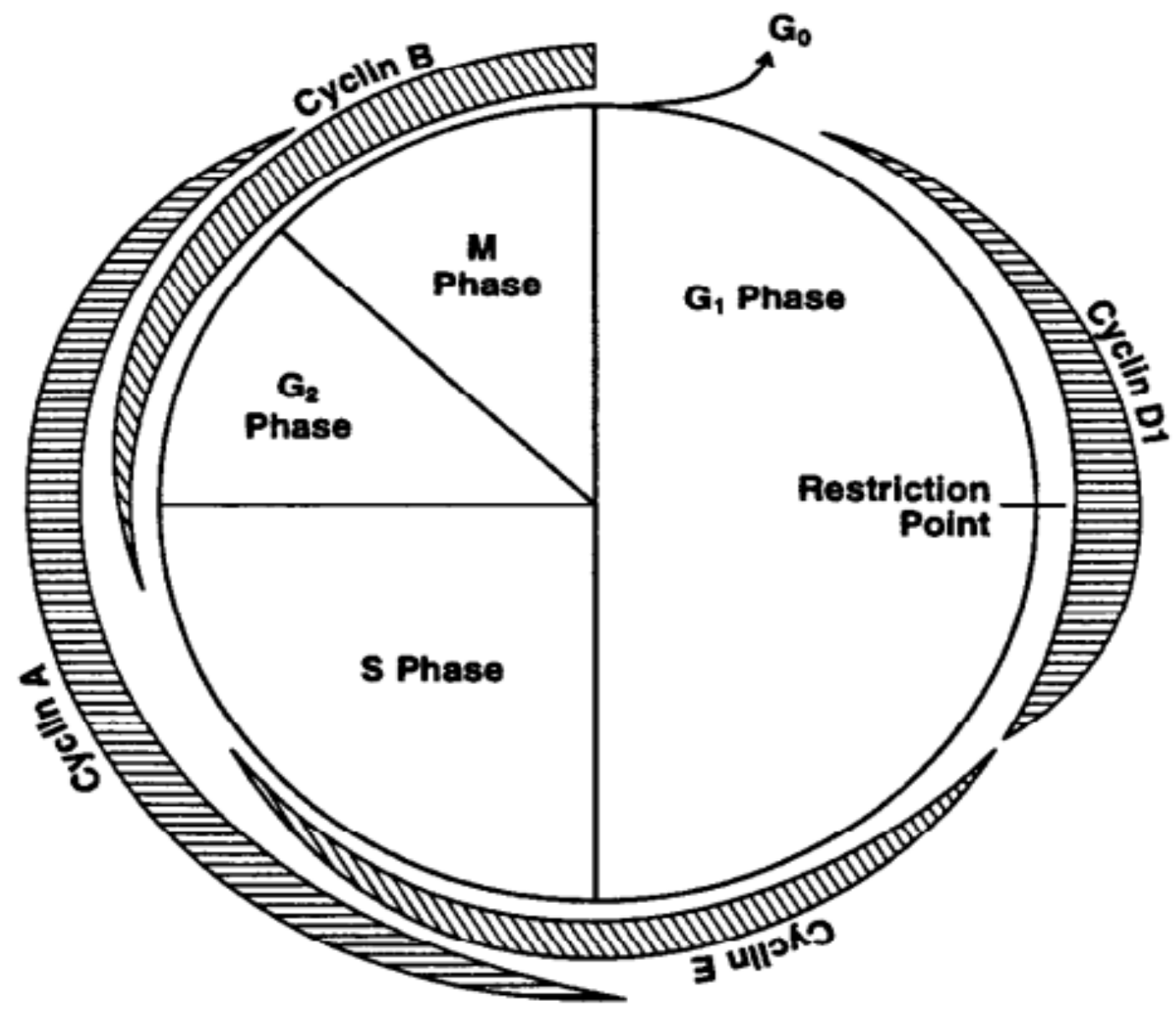

Figure 2-2: Schematic diagram of cell cycle phases and respective cyclin expression in each phase [126].

\subsection{1 $\mathrm{G}_{0}$ Phase}

Cells that have temporarily exited the cell cycle are classified as within the quiescent $\mathrm{G}_{0}$ phase. This phase is associated with differentiated function of many cell types in the body $[166,167]$. Cells can remain in $\mathrm{G}_{0}$ stasis for indefinite periods of time until stimulated to progress through the cell cycle by external signaling factors [167]. Identification of quiescent cells commonly involves absence of cell proliferation markers such as cyclins and cdks [167]. Most chondrocytes in adult articular cartilage tissue are within the $\mathrm{G}_{0}$ phase outside of the cell cycle $[168,169]$. This leads to a characteristic lack of division and proliferation in the tissue that also contributes to its limited capacity for repair $[170,171]$. Regulation of continued cell cycle stasis occurs through several documented pathways in human cells [167]. 


\subsection{2 $\mathrm{G}_{1}$ Phase}

The G1 phase is characterized as the gap phase between mitosis and subsequent synthesis required for progression through the cycle $[126,146]$. This phase is termed a checkpoint as newly formed daughter cells within $G_{1}$ are observed to grow and verify that they do not have any structural damage, which would prevent them from completing a successful cell cycle $[146,147]$. Cells in the $\mathrm{G}_{1}$ phase are observed to be metabolically active, and continually growing [146]. Cyclins D1, D2, and D3 actively regulate progression in this phase through binding of cdk4 and cdk6, creating a complex that inactivates a cell cycle progression inhibitor through phosphorylation $[127,128,148-150]$. These cyclins have a short halflife of less than 30 minutes in vivo, so a considerable amount of external signaling is required to increase the expression of cyclins [149]. Once sufficient cyclin D-cdk4/6 activation has occurred to inactivate cycle inhibitors, the cell has progressed past a specific point in the $\mathrm{G}_{1}$ phase termed the restriction point, after which the cells are committed to replicating DNA and completing a division cycle without the need for external stimulation $[149,150]$. Progression past this restriction point requires the initial presence of growth factors specific to the cell type in question to activate cyclin and cdk signaling [147, 149]. Cells that progress to the $G_{1}$ restriction point while lacking the appropriate growth factors for cyclin and cdk synthesis return to $G_{0}$ stasis $[147,150]$. Progression of late $G_{1}$ phase cells into $S$ phase requires the presence of cyclins E1 and E2, which primarily bind cdk1, cdk2, and cdk3 to phosphorylate target molecules that prevent DNA synthesis, inactivating these DNA replication inhibitors [150]. In a typical 24-hour cell cycle, the $\mathrm{G}_{1}$ phase lasts approximately 11 hours [129]. A study of the cell cycle of murine growth plate chondrocytes has observed the $\mathrm{G}_{1}$ phase length to be the most variable of all phases, with an average duration of approximately 21.2 hours [130].

\subsubsection{S Phase}

The S phase is characterized by synthesis of new DNA within the nucleus in addition to production of a new centrosome that is critical to the early stages of mitosis [151]. DNA synthesis is a highly regulated process as the precision and accuracy of the replication dictates the chromosomes of the 
resulting daughter cells [152]. Through DNA polymerase transcription, these chromosomes and their copies are responsible for the structure and function of the daughter cells, so several measures are in place to ensure precise duplication of the DNA, including selectivity of the nucleotides appended, proofreading of replicated strands, correction of mismatched base pairs, and repair of lesions to the DNA strand [152]. DNA replication begins with unwinding the DNA from its double helical form via a hydrolysis reaction driven by the DNA helicase enzyme, allowing DNA polymerase to bind free floating nucleotides (the monomers of DNA) that complement the nucleotide on the single strand of DNA (adenine to thymine and cytosine to guanine) $[152-154,156]$. Affinity of these nucleotide base pairs to their complements is strong, and allows for swift detection of errors in DNA replication $[152,153]$. If detected DNA damage is minimal, then replication is halted while the DNA polymerase enzyme repairs the strand, but if the damage is excessive the cell is committed to apoptosis and the genetic material is destroyed [154,155]. Synthesis is relatively rapid, with production of transcribed nucleotides occurring at rates of approximately 40 nucleotides per second in eukaryotic cells [156]. Late S phase is characterized by expression of cyclin A2, which binds cdk1 and cdk2 to form complexes that inactivate several target molecules such as CDC6, a cell division controlling protein [157]. In a typical 24-hour cell cycle, the S phase lasts approximately 8 hours [129]. A study of the cell cycle of murine growth plate chondrocytes has measured an average S phase length of approximately 6.1 hours [130].

\subsection{4 $\mathrm{G}_{2}$ Phase}

The $\mathrm{G}_{2}$ phase is characterized as the gap between synthesis of DNA and subsequent mitosis [157]. It is comprised of further cell growth and relevant secretion of the cyclins and cdks that are required for progression through mitosis, namely cyclin B isoforms and the cdk1 that they activate $[127,128,157$ 159]. Additionally, tubulin proteins and MAP kinases are synthesized that enable progression through subsequent mitotic phases $[127,160,161]$. Cyclins B1 and B2 are upregulated early in this phase, in which they also bind cdk1 to activate growth arrest and DNA damage genes that code for GADD45 proteins [162-163]. These proteins carry out the primary check in the $\mathrm{G}_{2}$ phase to detect for damage in the 
replicated DNA [162-165] In a typical 24-hour cell cycle, the $\mathrm{G}_{2}$ phase lasts approximately 4 hours [129]. A study of the cell cycle of murine growth plate chondrocytes has observed an average $\mathrm{G}_{2}$ phase length of approximately 3.0 hours [130].

\subsubsection{Phase}

The $\mathrm{M}$ phase is characterized by mitosis and cytokinesis. Mitosis is a complex, highly regulated set of processes by which a tetraploid (4n) cell divides to produce two genetically identical diploid cells [135]. Cytokinesis refers to the physical splitting of a tetraploid cell into two diploid cells [136]. Expression of cyclins B1 and B3 and their corresponding cdk1 are required for progression of the cell through the mitotic phase such as chromosome condensation and nuclear envelop degradation $[127,128$, 137].. Cyclin B1 activity is also linked with apoptosis of cells that contain damaged DNA, and it plays a critical role in the creation of the mitotic spindle $[137,138]$. In a typical 24 -hour cell cycle, the full sequence of events associated with mitosis occurs within 1 hour [129]. A study of the cell cycle of murine growth plate chondrocytes has measured an average M phase length of approximately 30-35 minutes [130]. Mitosis can be further broken down into five distinct phases in which the cell prepares for cytokinesis, shown in Figure 2-3. 
$\mathrm{G}_{2}$ OF INTERPHASE

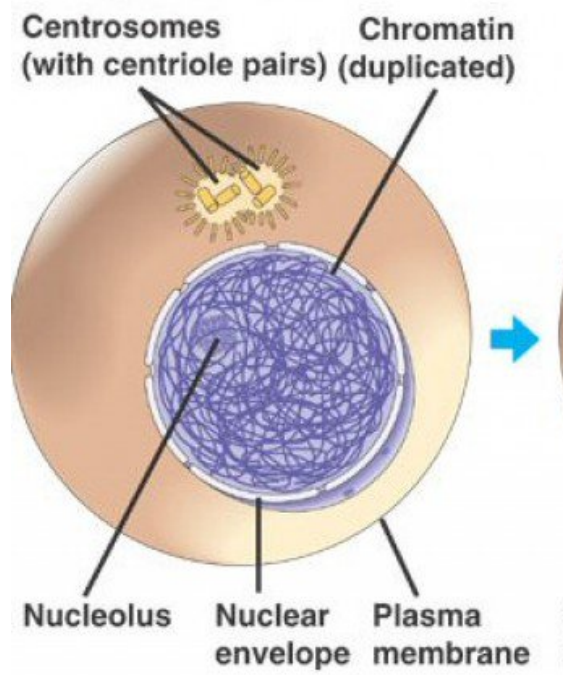

METAPHASE

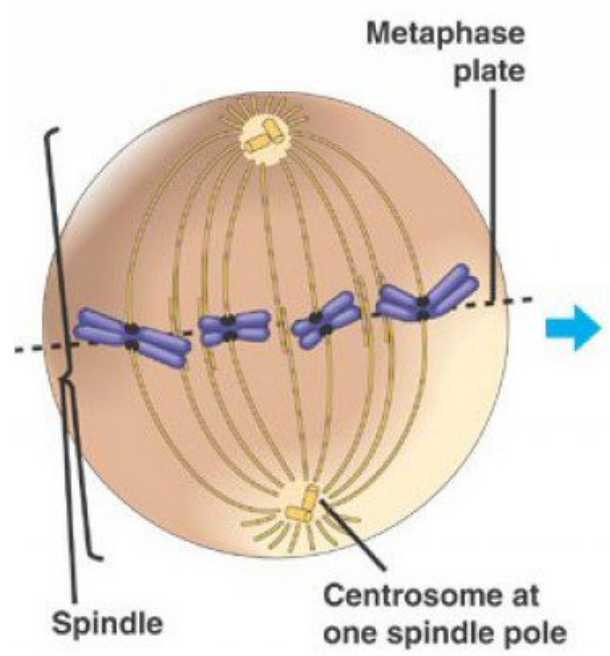

PROPHASE

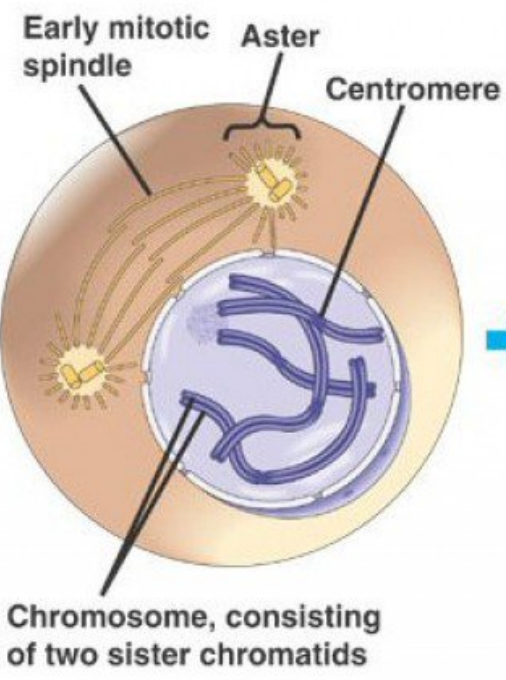

ANAPHASE

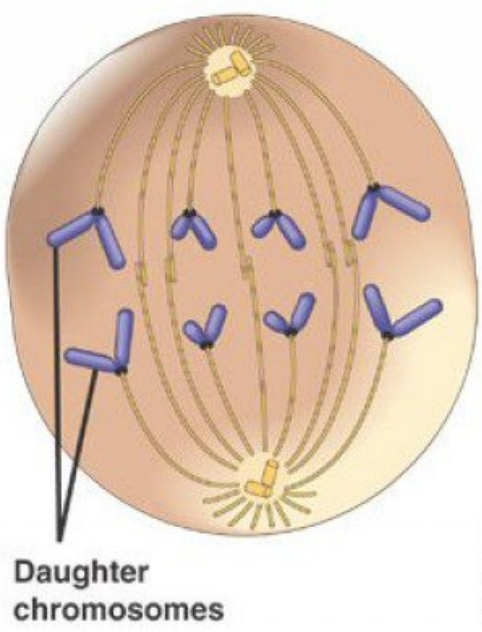

PROMETAPHASE

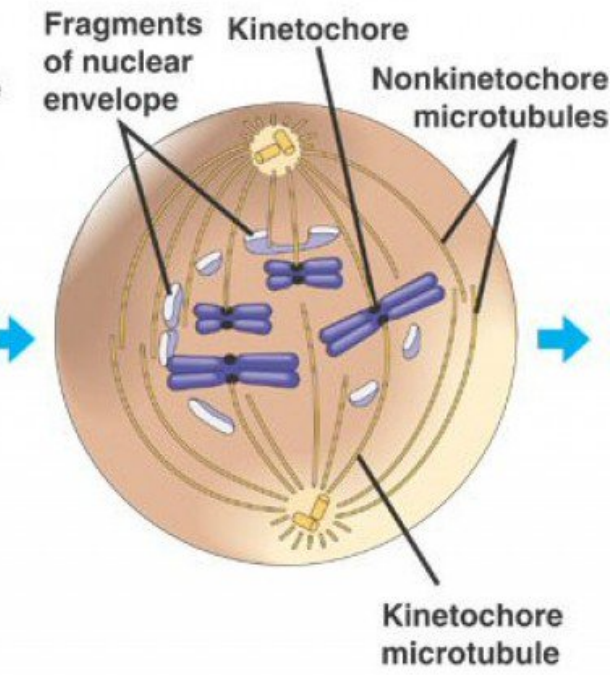

TELOPHASE AND CYTOKINESIS

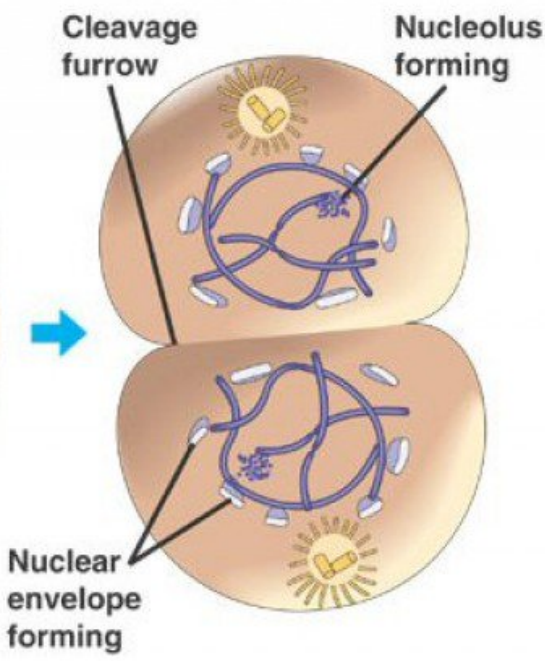

Figure 2-3: Characterization of the phases of mitosis in a eukaryotic cell [139].

The first mitotic phase is called prophase, in which newly replicated and verified chromosomes condense into tightly packed form, ensuring they can be moved with ease in later stages [140]. The formation of the mitotic spindle is visible at the edges of cells $[139,140]$. The mitotic spindle is a spindle structure composed of $\alpha$-tubulin and $\beta$-tubulin derived microtubule proteins that lengthen during prophase to lengthen the cell for division [140-142]. The subsequent phase is prometaphase, which is characterized by the breakdown of the nuclear envelope that encloses the chromosomes within the cell 
$[131,142]$. This breakdown allows chromosomes in the cell to come into direct contact with the microtubules of the mitotic spindle ahead of their interaction in metaphase [142]. In metaphase, the chromosome pairs form a line at the equator of the cell, with enough separation to ensure they do not come into contact with each other [143]. Once chromosome pairs are aligned the cell progresses into anaphase, where sister chromatids of each chromosome are separated toward opposite poles of the cell along the mitotic spindle $[142,144]$. Once complete, identical copies of genetic material are located on both sides of the cell and the microtubules of the mitotic spindle shorten [144]. In the final stage of mitosis, called telophase, the nuclear envelope encasing chromosomes begins to reform as two separate nuclear envelopes around the identical sets of sister chromatids on opposite sides of the cell, forming two nuclei [145]. A slight pinch at the equator is visible at the end of telophase, indicating the cell is ready for cytokinesis [145]. In cytokinesis, the cytoplasmic fluid and cellular contents are divided evenly between the two daughter cells, which are physically separated when actin fibers located in the center of the cell contract, pushing the two nuclei further apart and closing the cytoplasmic membrane around the two new daughter cells $[131,136]$.

\subsubsection{Synchronization}

Cell cycle synchronization is a term for the processes by which cell cycle phase of a population of cells can be manipulated such that cells within that population are brought to an identical phase of progression [181]. Methods of synchronization depend on the phenotype of the population in question, and are most commonly geared towards common methods of in vitro culture (e.g. monolayer) [182]. In vitro culture relies upon effective application of these synchronization techniques to analyze the properties of cells undergoing cell cycle phase-related events [183-185]. These techniques can be divided into two primary methods of characterization: physical (cell separation) and metabolic (chemical blockade) $[186,187]$. 


\section{Cell Separation}

Methods of physical separation can be utilized to synchronize a population of cells cultured in vitro [186]. Cells undergoing specific events within the cell cycle exhibit changes to shape, size, DNA content, and other distinguishing physical features that are discernible under microscopic examination and capable of being separated by practical lab methods [183-186]. These methods include mitotic shake off and cell sorting based on a variety of parameters including cell size and DNA content [183-186]

\section{Chemical blockade}

Methods of chemical treatment can be utilized to synchronize a population of cells cultured in vitro. The most common techniques that utilize chemical treatment are inhibitory regulators, which prevent progression past a specific stage of the cell cycle [187]. Chemicals such as hydroxyurea, thymidine, nocodazole, lovastatin, colcemid, aphidicolin, and RO-3306 [188-194]. Table 2-1 below shows several synchronization techniques and the phase in which cells are arrested [188-194].

\begin{tabular}{|c|c|}
\hline Synchronization Technique & Cell Cycle Phase of Arrest \\
\hline Serum Starvation & $\mathrm{G}_{0}$ \\
\hline Lovastatin & $\mathrm{G}_{1}$ \\
\hline Hydroxyurea & $\mathrm{S}$ \\
\hline Thymidine & $\mathrm{S}$ \\
\hline Aphidicolin & $\mathrm{S}$ \\
\hline Nocodazole & $\mathrm{M}$ \\
\hline RO-3306 & $\mathrm{M}$ \\
\hline Colcemid & $\mathrm{M}$ \\
\hline
\end{tabular}

Table 2-1: In Vitro cell cycle synchronization agents and respective phases of cell cycle arrest.

Hydroxyurea and thymidine both arrest cells in the S phase, though their mechanisms of arrest differ [188]. Hydroxyurea causes arrest via inhibition of ribonucleotide reductase enzymes responsible for the production of the nucleotides incorporated in DNA synthesis $[188,189]$. Conversely, thymidine operates 
by overload mechanism, wherein excess thymidine content halts DNA synthesis by inhibiting nucleotide addition to replicated strand DNA to prevent nucleotide base-pair mismatch [188]. Serum starvation is a less effective method of arresting cells in the $\mathrm{G}_{0}$ phase of the cell cycle $[195,196]$. The mechanism involves depriving cells of the nutrients and growth factors in serum that are required for growth and progression of the cell past the restriction point in $G_{1}$ at which they commit to division [196].

\subsubsection{Characterization}

Characterization of cell cycle can be done based on physical indicators or antibody markers of cell cycle phase $[186,187]$. Two methods of characterization that are easily performed using modern analysis procedures are cell size and DNA content, which change throughout the cell cycle [186, 197]. In addition, expression of cyclin proteins and associated cdks provides strong information about the exact phase in which a single cell resides and even what specific set of events within that phase the cell is undergoing at the time of analysis $[127,128]$. This makes fluorescent-tagged antibodies of these cyclin proteins useful indicators of cell cycle phase [198].

\section{Flow Cytometry}

Flow cytometry characterization of cell cycle is commonly conducted through analysis of DNA content $[199,200]$. DNA binding dyes that fluoresce when bound to double stranded DNA and excited by a specific wavelength of light are frequently used to stain live or fixed populations to analyze the number of cells in each phase $[199,200]$. Commonly utilized DNA binding dyes for cell cycle analysis of fixed cells include propidium iodide, DAPI, and Hoechst 33342, while similar dyes for live cells include the Vybrant DyeCycle staining kits [199, 200]. Highly specific antibodies have been conjugated with fluorescence-emitting proteins or beads for some cyclin proteins in specific species, but a full panel of cyclin expression cannot be developed for flow cytometry, ruling it out as a comprehensive tool for examining cell cycle progression of live cells [201]. Flow cytometry also offers the benefit of providing the single cell analysis of multiple populations in a short time frame since populations of cells stained 
with the appropriate dyes can be analyzed for their DNA content or presence of a fluorescent marker instantaneously [202].

\section{Western Blot}

Characterization of the protein content of the population can be assessed through western blotting [203] This technique has previously been utilized to characterize cdk protein expression in order to ascertain cell cycle of in vitro cultured populations of cells under certain treatment [203-205].

However, since the cell cycle is time dependent, the time required to perform a western blot on a panel of cyclin proteins is excessive compared to the half-life of the cyclin and cdk proteins [206]. Thus, this method cannot provide information about time-sensitive cell cycle phase information [206]. 


\section{Chapter 3 Methods}

All reagents utilized in this study were obtained from Sigma Aldrich Ltd. (Oakville, ON, Canada) unless otherwise specified.

\subsection{Culturing Populations of Synchronized Primary Articular Chondrocytes}

In order to assess the potential for improved growth in synchronized versus unsynchronized populations of primary articular chondrocytes (PACs), an optimal method was determined to synchronize this differentiated phenotype without the requirement of cells being seeded in monolayer.

\subsubsection{Articular Cartilage Tissue Harvest}

Articular cartilage explants were harvested from the metacarpophalangeal joints of cows younger than the age of 18 months under sterile conditions. These joints are found in the legs of cows, and are analogous to the diarthroid joint in the knee. Bovine cow legs with an intact metacarpophalangeal joint were obtained through the Kandel laboratory (Mount Sinai, Toronto, ON, Canada) from a local abattoir immediately after slaughter of the animals (Beverly Creek Farms, Milton, ON, Canada). Cartilage explants $(<5 \mathrm{~mm}$ x $5 \mathrm{~mm})$ were placed into a $100 \mathrm{~mm}$ petri dish containing complete media $(20 \mathrm{~mL}$ of Ham's F $12+10 \%$ fetal bovine serum $+1 \%$ antibiotics). Cells were obtained from these cartilage explants by enzymatic digestion of tissue with a $0.5 \% \mathrm{w} / \mathrm{v}$ protease (Sigma Aldrich Ltd.) solution for 1 hour and a $0.15 \% \mathrm{w} / \mathrm{v}$ collagenase A solution for 12 hours. Protease was prepared in Ham's F12 containing $25 \mathrm{mM}$ HEPES, while collagenase was prepared in the same media formulation containing an additional 10\% fetal bovine serum (Sigma Aldrich Ltd.).

\subsubsection{Synchronization of Tissue In Situ}

Several chemicals are known to arrest cell cycle progression, and are consequently used in cell culture to synchronize the cell cycle of a given population. These chemicals act to inhibit specific 
signaling pathways in the cell cycle, preventing the cells from progressing into the next phase and yielding cell cycle synchronized populations.

Cell cycle synchronization of PACs during the process of cell isolation was achieved by testing commonly used cell cycle arresting agents such as thymidine (G1/S phase), aphidicolin (G1/S phase), nocodazole $\left(\mathrm{G}_{2} / \mathrm{M}\right.$ phase), RO-3306 (G2/M phase), and the process of serum starvation $\left(\mathrm{G}_{\mathrm{o}} / \mathrm{G}_{1}\right.$ phase $)$ [207-210]. Isolation of the synchronized cells was achieved by coupling the 12 hour digestion in Collagenase A with the second arresting treatment of these protocols. Both cell viability (by counting using a haemocytometer) and cell cycle synchrony (by flow cytometric analysis and gating of cells in the target S phase) of populations were assessed for each technique. Haemocytometer counts were performed by mixing $10 \mu \mathrm{L}$ of trypan blue dye with an equal volume of cell suspension and mixing gently before pipetting $10 \mu \mathrm{L}$ of this mixure onto the surface between a haemocytometer and adjacent coverslip. Counts were performed under a brightfield microscope at 20x magnification, and a measure of viable cells (which had not taken in the dye) as well as total cells within the grid were averaged over four fields of view. This method was used to estimate population cell counts and population viabilities [211]. By tracking DNA content of individual cells in the population at short interval time points (12 hours) following the synchronization protocol, the cell cycle characteristics of the population could be analyzed and used to determine the optimal method of synchronization.

\subsubsection{Serum Starvation}

This method of synchronization involved first digesting the cells in a $0.5 \% \mathrm{w} / \mathrm{v}$ protease in Ham's F12 solution, followed by a wash with Ham's F12 media and a subsequent incubation of the explants in the absence of fetal bovine serum for a period of 12 hours (coupled with the enzymatic digestion of tissue by $0.15 \% \mathrm{w} / \mathrm{v}$ collagenase A in Ham's F12).

\subsubsection{Double Thymidine Block}

The double thymidine block involved blocking explants in a $60 \mathrm{~mm}$ petri dish with $20 \mathrm{~mL}$ of complete media containing an additional $10 \mathrm{mM}$ thymidine for 24 hours, followed by a wash with $5 \mathrm{~mL}$ 
Ham's F12 media and a release into 20 mL Ham's F12 media for 8 hours. After 8 hours the Ham's F12 media was aspirated and replaced with $20 \mathrm{~mL}$ of a solution of $0.5 \% \mathrm{w} / \mathrm{v}$ protease in Ham's F12 for 1 hour, followed by a wash with $5 \mathrm{~mL}$ Ham's F12 media and a second block in $20 \mathrm{~mL}$ of a solution of Ham's F12 media containing 10\% fetal bovine serum, $10 \mathrm{mM}$ thymidine, and $0.15 \% \mathrm{w} / \mathrm{v}$ collagenase A for a period of 12 hours, yielding a population in early S phase.

\subsubsection{Thymidine-Nocodazole Block}

The thymidine-nocodazole block followed the same procedure as the double thymidine block up until the release into Ham's F12 media, which was administered for a total of 3 hours. After 2 hours, the Ham's F12 media was aspirated and replaced with $20 \mathrm{~mL}$ of a solution of $0.5 \% \mathrm{w} / \mathrm{v}$ protease in Ham's F12 for 1 hour, followed by a wash with $5 \mathrm{~mL}$ Ham's F12 media and a second block in $20 \mathrm{~mL}$ of a solution of Ham's F12 media containing 10\% fetal bovine serum, 100 ng/mL nocodazole (Sigma Aldrich Ltd.), and $0.15 \% \mathrm{w} / \mathrm{v}$ collagenase A for a period of 12 hours, yielding a population in late $\mathrm{G}_{2}$ phase.

\subsubsection{RO-3306}

The RO-3306 block was used to achieve synchronization in late G2 phase by following the same procedure as the double thymidine block up until the release in Ham's F12 media, which was administered for 6 hours ( 5 hours in serum free media followed by a 1 -hour treatment of $0.5 \% \mathrm{w} / \mathrm{v}$

protease in Ham's F12 media). The explants were then treated with $20 \mathrm{~mL}$ of a solution of Ham's F12 containing 10\% fetal bovine serum, $10 \mu \mathrm{M}$ RO-3306, and $0.15 \% \mathrm{w} / \mathrm{v}$ collagenase A for a period of 12 hours, yielding a population in late G2 phase.

\subsubsection{Aphidicolin}

The aphidicolin block was used to achieve synchronization in early $\mathrm{S}$ phase by first serum starving the explants (incubation in $20 \mathrm{~mL}$ of Ham's F12 media in a $60 \mathrm{~mm}$ petri dish) for 48 hours. For the first 47 hours of this starvation, explants were incubated in Ham's F12, and in the last hour they were treated with a solution of $0.5 \% \mathrm{w} / \mathrm{v}$ protease in Ham's F12 media. This was followed by a wash with 
Ham's F12 media, and a subsequent 24-hour treatment of Ham's F12 media containing 10\% fetal bovine serum, $5 \mu \mathrm{g} / \mathrm{mL}$ aphidicolin and $0.15 \% \mathrm{w} / \mathrm{v}$ collagenase A, yielding a population in early S phase.

\subsubsection{Altered Double Thymidine Block}

The double thymidine block was selected as the synchronization method, for which time points were selectively changed for optimization of the cell cycle synchronization process. The optimized double thymidine process involved cutting slices into small $(<5 \mathrm{~mm} \times 5 \mathrm{~mm})$ sections of tissue and administering a $24 \mathrm{hr}$ treatment of $10 \mathrm{mM}$ thymidine (Sigma Aldrich) in Ham's F12 with 25 mM HEPES and 10\% FBS (UofT MedStore) to the cartilage sections. This first block of thymidine treatment was followed by aspiration of the thymidine media and a wash in Ham's F12 media, and finally an 8 hour release into F12 media. After the 8 hour release, the sections were treated with a 1 hour protease digestion $(0.5 \% \mathrm{w} / \mathrm{v}$, prepared in Ham's F12 media) for a total release time of 9 hours. Finally, the synchronized population was washed in F12 media to remove any traces of protease in the petri dish, and treated with collagenase as it underwent a second thymidine block $(0.15 \% \mathrm{w} / \mathrm{v}$ collagenase $\mathrm{A}, 10 \mathrm{mM}$ thymidine, prepared in Ham's F12 + 10\% FBS). 


\subsection{Hydrogel Immobilization}

In order to maintain phenotype of PACs in culture, they were encapsulated in hydrogel materials in high cell density $\left(20 \times 10^{6}\right.$ cells $\left./ \mathrm{mL}\right)$. The use of hydrogels allowed for a consistent scaffold material that was similar in mechanical properties to that of native tissue. Two materials and different applications of their gelation were tested for their ability to encapsulate the populations of PACs and later recover them from encapsulation in order to assess their cell cycle phase after fixed time points in culture. Viability of recovered populations was measured using haemocytometer counts of trypan blue stained samples, as described in section 3.1.2.

\subsubsection{Agarose Cylinders}

A custom Teflon mold was used to create agarose cylinder constructs seeded with primary chondrocytes suspended at high density. The mold had two interlocking elements that form the shape in which the seeded agarose cylinders set. A solution of $4 \% \mathrm{w} / \mathrm{v}$ agarose (Sigma Aldrich) in a 1X PBS solution at $\mathrm{pH} 7.4$ was mixed in equal parts with a cell suspension of either control or synchronized cell populations in Ham's F12 with $25 \mathrm{~mm}$ HEPES at pH 7.4 (density of $20 \times 10^{6}$ cells $/ \mathrm{mL}$ ) at $40^{\circ} \mathrm{C}$ under magnetic stir bar agitation. This formed a $2 \% \mathrm{w} / \mathrm{v}$ cell seeded agarose gel solution with cells at density 10 x $10^{6}$ cells $/ \mathrm{mL}$. 3-dimensional cylinder constructs were cast from this mixture into the Teflon mold and allowed to cool at room temperature for 10 minutes, after which they were extracted from the mold using forceps and put into culture.

\subsubsection{Alginate Cylinders}

The same custom Teflon mold was used to generate an agarose negative template from which alginate cylinder constructs were cast and seeded with primary articular chondrocytes at high density. The agarose negative template was created by creating a $4 \% \mathrm{w} / \mathrm{v}$ agarose solution in $1 \mathrm{X} \mathrm{PBS}+50 \mathrm{mM} \mathrm{CaCl}_{2}$ at $\mathrm{pH}$ 7.4. A high-density chondrocyte cell suspension $\left(20 \times 10^{6}\right.$ cells $\left./ \mathrm{mL}\right)$ was mixed in equal parts with a sterile $1.25 \%$ alginic acid solution (20 mM HEPES, $150 \mathrm{mM} \mathrm{NaCl}, \mathrm{pH} 7.4$ ) at room temperature. In the 
cast agarose template, the alginate-cell suspension solution was dispensed $30 \mu \mathrm{L}$ at a time to fill each individual cylindrical space. Following this, the filled agarose template was placed in a sterile filtered solution of $110 \mathrm{mM} \mathrm{CaCl}_{2}$ (buffered with $10 \mathrm{mM}$ HEPES at $\mathrm{pH}$ 7.4) for 10 minutes, following which the cylinder constructs were extracted from the template with forceps and put into culture.

\subsubsection{Alginate Beads}

Primary articular chondrocyte encapsulated alginate beads were created by first mixing a highdensity cell suspension of chondrocytes $\left(20 \times 10^{6}\right.$ cells $\left./ \mathrm{mL}\right)$ in equal parts with a sterile $1.25 \%$ alginic acid solution (20 mM HEPES, $150 \mathrm{mM} \mathrm{NaCl}$, pH 7.4) at room temperature. This suspension of chondrocytes in alginate was polymerized by being added in $30 \mu \mathrm{L}$ drops in a sterile polymerization solution (110 $\mathrm{mM} \mathrm{CaCl}_{2}$ buffered with $10 \mathrm{mM}$ HEPES at pH 7.4). After 10 minutes in the polymerization solution, the 3-dimensional bead constructs were extracted using sterilized forceps and placed into culture.

\subsubsection{Recovery}

Cells were required to be recovered from encapsulation in order to assess their cell cycle phase using flow cytometry techniques. Alginate beads and cylinders dissociated in 15 minutes at $37^{\circ} \mathrm{C}$ under light agitation (120 RPM) in a calcium chelating EDTA solution ( $55 \mathrm{mM}$ EDTA in a solution of $5 \mathrm{~mL}$ of 1X PBS). Agarose cylinders did not dissociate under these conditions. Even in the presence of 10 units of a $\beta$-agarase enzyme, agarose constructs required significant heating (between $80-120^{\circ} \mathrm{C}$ ) to dissociate within a 15 minute duration. 


\subsection{Three-Dimensional Construct Culture}

Each construct was placed in a 24 well plate in a $37^{\circ} \mathrm{C}$ incubator $\left(5 \% \mathrm{CO}_{2}\right.$ and $95 \%$ humidity) and fed $1 \mathrm{~mL}$ of a solution of Ham's F12 $+10 \%$ fetal bovine serum $+1 \%$ antibiotics $+0.5 \%$ ascorbic acid, every 48 hours. Constructs were cultured for a maximum of 4 weeks.

\subsection{Analysis of Constructs at 2 and 4 Weeks}

Constructs were harvested for analysis at 2-week and 4-week time points from the first day in culture. This provided sufficient time to determine any differences in matrix synthesis that could have occurred in culture.

\subsubsection{Characterization of Cell Cycle using Flow Cytometry}

Analysis of the cell cycle of populations was performed using flow cytometry. Control (unsynchronized) populations were used to establish the staining region of $\mathrm{G}_{0} / \mathrm{G}_{1}$ cells, whilst cells that fluoresced with twice the intensity exhibited twice the amount of DNA and thus were in the $\mathrm{G}_{2} / \mathrm{M}$ phase. Cell cycle phase of synchronized and unsynchronized populations was examined using standard flow cytometry techniques. These were tested using both a live cell stain (Vybrant DyeCycle Ruby) and a dead cell stain (propidium iodide), both of which provided a measure of DNA content.

\subsubsection{Vybrant DyeCycle Ruby}

Vybrant DyeCycle Ruby (ThermoFisher V10309, Whitby, ON, Canada) was used to ascertain the DNA content of a live population of PACs. The dye was allowed to equilibrate to room temperature, and cells were suspended in $5 \mathrm{~mL}$ of sterile $1 \mathrm{X}$ PBS at $5 \times 10^{5}$ cells $/ \mathrm{mL}$. In a polypropylene FACS tube protected from light, $10 \mu \mathrm{L}$ of the dye were added to cells suspended in 1X PBS for a final concentration of $5 \mu \mathrm{M}$. The tubes were placed in an incubator $\left(37^{\circ} \mathrm{C}\right)$ protected from light for 30 minutes, allowing the dye to bind to the nucleic acid in the sample before being analyzed on a BD FACSAria cell sorter. The fluorochrome was excited by a blue $(488 \mathrm{~nm})$ laser and the emission spectra in the 653-675 $\mathrm{nm}$ range was analyzed to determine DNA content of each cell. 


\subsubsection{Propidium Iodide}

Propidium iodide was used to ascertain the DNA content of $70 \%$ ethanol-fixed populations of PACs. Samples were prepared by pelleting cells of each population through centrifugation at $700 \mathrm{x} g$ for 10 minutes. The supernatant media was aspirated and cell pellets were resuspended in Ham's F12 media (+ 25 mM HEPES, $\mathrm{pH}$ 7.4) and from this cell suspension, $1 \mathrm{~mL}$ was removed using a sterile polyethylene pipette. The cell suspension was fixed by being added dropwise to $4.5 \mathrm{~mL}$ of $80 \%$ ethanol $\left(-20^{\circ} \mathrm{C}\right)$ that was being vortexed to prevent aggregation of the cells, and left on ice for 30 minutes. Following this fixation, the cells were again pelleted through centrifugation at $1000 \mathrm{x} g$ for 5 minutes, and the supernatant ethanol was aspirated, followed by resuspension of the pellet in $5 \mathrm{~mL}$ of $1 \mathrm{X}$ PBS. Staining was done by first permeabilizing the cells using $100 \mu \mathrm{L}$ of a $10 \%$ Triton-x 100 solution to allow penetration of the dye solution. Finally, the cells were stained with $100 \mu \mathrm{L}$ of the dye solution which consisted of propidium iodide containing RNAse to degrade RNA that could bind the propidium iodide and skew representative data of DNA content (Abcam, Cambridge, MA, USA: ab139418), ahead of analysis on a BD FACSAria cell sorter. The cytometer excited the propidium iodide bound to the DNA with a blue $(488 \mathrm{~nm})$ laser and the emission spectra in the $653-675 \mathrm{~nm}$ range were analyzed to determine DNA content of each cell.

\subsection{Histological Evaluation}

Constructs were fixed in 4\% PFA for 24 hours and switched to suspension in $70 \%$ ethanol and secured in tissue processing cassettes ahead of tissue processing in a Leica TP1020 automatic tissue processor. Samples were then embedded in paraffin and allowed to cool, before being cut into $8 \mu \mathrm{m}$ sections on slides with a Leica RM2235 rotary microtome. Paraffin was chemically removed from the slides according to standard histology procedures [212]. This consisted of three treatments (5 minutes each) of xylene, followed by two treatments (10 minutes each) of 100\% ethanol, then two treatments (10 minutes each) of $95 \%$ ethanol, and a final wash step in deionized water, leaving only the re-hydrated 
tissue sections that were used to stain for cartilaginous matrix molecules such as collagens and glycosaminoglycans.

\subsubsection{Safranin Oxide Staining}

Sections were stained with Weigert's Hematoxylin (10 minutes), followed by a wash under running tap water for 10 minutes and staining in $0.25 \%$ Fast Green solution for 5 minutes. A rinse in $1 \%$ acetic acid for 10 seconds and a final stain in $0.1 \%$ safranin oxide solution were performed on sections before dehydration of the slides in successive washes ( 2 minutes each) of $95 \%$ ethanol, $100 \%$ ethanol, and xylene. Subsequently, slides were then mounted with coverslips using toluene mounting media and allowed to set overnight.

\subsubsection{Sirius Red Staining}

Sections were stained with Weigert's Hematoxylin ( 8 minutes) followed by a wash under running tap water for 10 minutes. Sections were then stained for one hour in a solution comprised of $0.5 \mathrm{~g}$ Sirius Red in $500 \mathrm{~mL}$ of a saturated aqueous solution of picric acid. Two rinses in $1 \%$ acetic acid were performed on the sections followed by a short wash (1 minute) under tap water and dehydration of the slides in successive washes of $95 \%$ ethanol, $100 \%$ ethanol, and xylene. Subsequently, slides were then mounted with coverslips using toluene mounting media and allowed to set overnight. 


\subsection{Immunohistochemical Evaluation}

Evaluation of antigens present on the cells in this culture model allowed detection of expressed markers that are phenotypically specific. These markers were used to confirm matrix quantification and maintained articular chondrocyte phenotype.

\subsubsection{Collagen I and II staining}

Sections were treated with a solution of $3.9 \mathrm{kU} / \mathrm{mL}$ pepsin containing $0.5 \%$ acetic acid for 30 minutes in an incubator $\left(37^{\circ} \mathrm{C}\right)$, followed by two washes with $1 \mathrm{X}$ PBS. The sections were then blocked with a solution of $1 \%$ bovine serum albumin in $1 \mathrm{X}$ PBS for 30 minutes at room temperature. Following this, sections were incubated with a primary collagen I (ab90395, obtained from Abcam, Cambridge, MA, USA) or collagen II (CIIC1, obtained from DSHB, Iowa City, IA, USA) antibody (1:100) overnight in a fridge at $4^{\circ} \mathrm{C}$. Another two washes with $1 \mathrm{X}$ PBS were performed to remove the excess primary antibody, followed by staining with a secondary antibody (ab150115, obtained from Abcam, Cambridge, MA, USA) at room temperature for two hours. Three washes with $1 \mathrm{X}$ PBS were performed to remove excess secondary antibody, followed by mounting coverslips on the slides using Vectashield mounting medium containing DAPI.

\subsection{Biochemical Evaluation}

In order to assess the growth and chondrogenesis, constructs were harvested into $1.5 \mathrm{~mL}$ Eppendorf tubes after 2 weeks and 4 weeks in culture and biochemical assays were performed to determine extracellular matrix accumulation and cellularity. 


\subsubsection{Water content}

The water content in each construct was determined by measuring the wet weight of each construct and comparing with dry weight of each construct after a lyophilization process.

Following lyophilization, the constructs were each given $600 \mu \mathrm{L}$ of a digestion solution of papain in papain buffer $(1.5 \mu \mathrm{L} / \mathrm{mL})$ and placed on a heating block at $65{ }^{\circ} \mathrm{C}$ for 72 hours. Subsequent digests of each sample were used in the following 3 assays.

\subsubsection{DNA content}

The QuantIT PicoGreen DNA binding dye assay provided a measure of the cellularity of the constructs [213]. This was done by quantifying standard solutions of a known amount of DNA isolated from calf thymus via fluorescent detection of emission spectra in the $520 \mathrm{~nm}$ range when excited with light in $480 \mathrm{~nm}$ range. By subjecting samples (performed in triplicate) to the same wavelength of excitation, the concentration of DNA in each sample was determined based on the emission spectra, which were then compared to the standard curve of concentration vs emission generated for known concentrations of calf thymus DNA. Accounting for dilution factors and volumes of digested sample allowed for an accurate assessment of the mass of DNA in each sample.

\subsubsection{Hydroxyproline Assay for Collagen Content}

A measure of the collagen content in each construct was found by measuring the hydroxyproline content of the constructs, which provides an indirect measurement of the collagen content through the well documented hydroxyproline assay. This was done by first hydrolyzing a set volume of $100 \mu \mathrm{L}$ of sample digest with an equal amount of $6 \mathrm{~N}$ hydrochloric acid at $65^{\circ} \mathrm{C}$ for 72 hours. The hydrolyzates were then neutralized with $100 \mu \mathrm{L}$ of $5.7 \mathrm{~N} \mathrm{NaOH}$, and diluted with $200 \mu \mathrm{L}$ of deionized water. Quantification of hydroxyproline content was done through generation of standard solutions of a known amount of hydroxyproline, and comparisons of absorbance spectra of wavelength $560 \mathrm{~nm}$. By observing absorbance of samples (performed in triplicate) at the same wavelength, the concentration of hydroxyproline in each 
sample can be determined based on absorbance detection, which is then compared to the standard curve generated to ascertain the concentration of hydroxyproline in each sample. By accounting for dilution factors and a ratio of hydroxyproline to collagen molecules during the hydrolyzation and processes, the mass of collagen in each sample is resolved. Collagen content was estimated as 10X the hydroproline content [214].

\subsubsection{DMMB Assay for Sulfated GAG Content}

A measure of the proteoglycan content in each construct was found by measuring the sulfated glycosaminoglycan content in each construct using the dimethylmethylene blue-binding dye assay [215]. This was done by quantifying standard solutions of a known amount of DNA isolated from calf thymus via absorbance spectra in the $525 \mathrm{~nm}$ range. By observing absorbance of samples (done in triplicate) to

the same wavelength, the concentration of DNA in each sample was determined based on the fluorescent detection, which was then compared to the standard curve of quantified concentrations of chondroitin sulfate generated to determine mass of sulfated glycosaminoglycans in the sample. 


\section{Chapter 4 Results}

\subsection{Effect of Cell Cycle Synchronization Treatments on Primary Articular Chondrocytes}

Primary articular chondrocytes were synchronized in different phases of the cell cycle using synchronizing agents to determine the best method for yielding synchronized, viable populations. Samples were analyzed for viability immediately after isolation, and success of the synchronization techniques was assessed through flow cytometric analysis of samples to determine DNA content as a measure of cell cycle phase.

\subsubsection{Viability of Synchronization in Primary Articular Chondrocytes}

The trypan blue dye exclusion method was used to determine viability of recovered populations during isolation coupled with each synchronization method. Counts on 4 separate fields of view were averaged and used to determine the number of live cells and total cells in each synchronized sample.

\begin{tabular}{|l|c|c|}
\hline \multicolumn{1}{|c|}{ Synchronization Technique } & $\begin{array}{c}\text { \% Viability of Population } \\
\text { (live cells/total) }\end{array}$ & $\begin{array}{c}\text { \% Purity of Population } \\
\text { (in phase of interest) }\end{array}$ \\
\hline Control (Untreated Isolation) & $97.5 \pm 0.1 \%$ & $83.3 \pm 0.7 \%$ in $\mathrm{G}_{0} / \mathrm{G}_{1}$ \\
\hline Double Thymidine Block & $96.3 \pm 0.2 \%$ & $60.7 \pm 1.1 \%$ in $\mathrm{S}$ \\
\hline Modified Double Thymidine Block & $95.2 \pm 0.1 \%$ & $92.7 \pm 0.3 \%$ in S \\
\hline Nocodazole & $42.8 \pm 0.5 \%$ & $77.3 \pm 5.8 \%$ in $\mathrm{G}_{2} / \mathrm{M}$ \\
\hline Aphidicolin & $89.3 \pm 0.2 \%$ & $81.0 \pm 2.5 \%$ in $\mathrm{S}$ \\
\hline RO-3306 & $85.9 \pm 0.4 \%$ & $6.6 \pm 0.4 \%$ in $\mathrm{M}$ \\
\hline
\end{tabular}

Table 4-1: Viabilities and purities of populations subjected to synchronization techniques. Viability presented as live cells as a percentage of total cells in the sample \pm the standard error of the mean. Purity was presented as the number of cells falling within the gated region of the phase of interest \pm the standard error of the mean. ( $n=3$ per group) 
Table 4-1 shows the effects of these synchronizing techniques on the viability and cell cycle phase of primary articular chondrocytes. The double thymidine block and its modified version demonstrated the highest percentage of cells synchronized within the phase of interest, while maintaining viability of the populations above $90 \%$. The modified double thymidine block also had a significantly higher percentage of cells accumulated in the gated region for the $\mathrm{S}$ phase $(\mathrm{P}<0.05)$, and was chosen as the optimal method of synchronizing primary articular chondrocytes. As shown in Table 4-1, decreased viability and lack of a highly synchronized population in other synchronization techniques were distinct, which were the two reasons those methods were not investigated further. In particular, nocodazole synchronization in the late $\mathrm{G}_{2}$ /early $\mathrm{M}$ phase was shown to elicit the lowest viability (42.8\%) of all synchronizing treatments, exhibiting the highest percentage of cells that had taken up the trypan blue dye, and was thus discounted.

Analysis of the cell cycle phase of populations from which constructs were seeded was conducted in FlowJo software through sample fixation and staining with propidium iodide. Stained samples were analyzed under blue laser (488nm) excitation and their emission in the 653-675nm range was measured to determine DNA content. This provided confirmation that experimental constructs were in fact seeded with synchronized primary articular chondrocytes. 


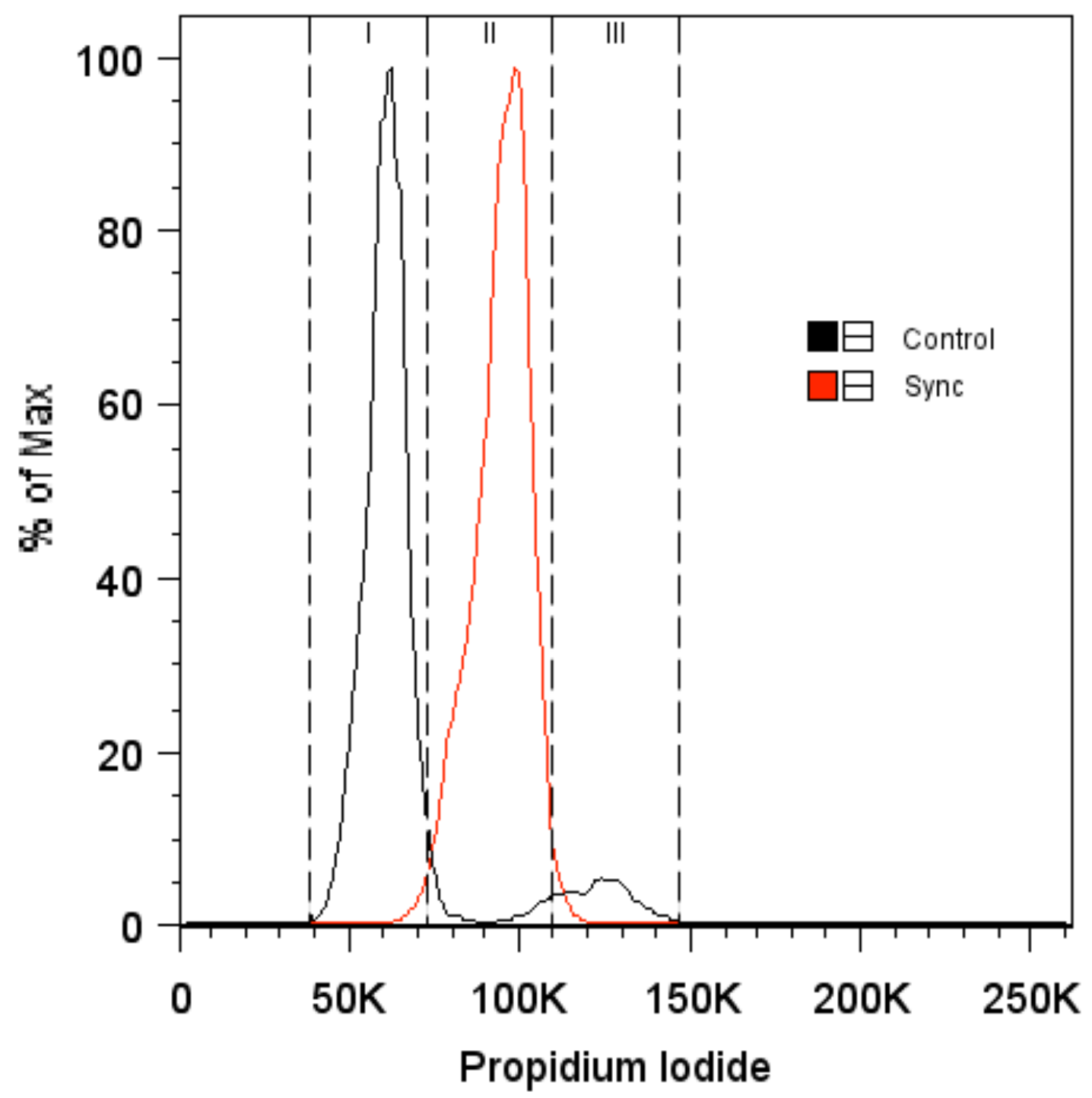

Figure 4-1: Representative samples of the cell cycle gated overlay of emission spectra of Control and Modified Double Thymidine Synchronized populations in the range of propidium iodide's emission spectra (653-675nm). I) Staining region for nuclei in the G0-G1 phase. II) Staining region for nuclei in the $S$ phase. III) Staining region for nuclei in the G2-M phase.

Through standard flow cytometry principles, the cell cycle phase of control and synchronized populations is demonstrated in Figure 4-1. Expression of diploid nuclei in the $G_{0} / G_{1}$ phase was gated around the normally distributed peak of the control group centered at 62,500 , with a width of 30,000 on the scale of emitted light intensity in the propidium iodide (653-675) emission spectra. The gate for the tetraploid cells in the $\mathrm{G}_{2} / \mathrm{M}$ phase was centered around the normally distributed peak centered at 125,000 
(twice the DNA content of a diploid primary articular chondrocyte resulting in twice the amplified fluorescence intensity signal) with the same width as the $G_{0} / G_{1}$ phase peak. The range of the synthesis phase gate was drawn between the two, comprising the cells that contained between one and two full sets of DNA. Based on these generated gates, the percentage of cells in each phase for these isolations was generated.

\begin{tabular}{|l|c|c|c|}
\hline \multirow{2}{*}{ Sample } & \multicolumn{3}{|c|}{ \% Histology in Phase } \\
\cline { 2 - 4 } & $\mathbf{G}_{\mathbf{0}} / \mathbf{G}_{\mathbf{1}}$ & $\mathbf{S}$ & $\mathbf{G}_{\mathbf{2}} / \mathbf{M}$ \\
\hline Control & $83.3 \pm 0.7 \%$ & $3.4 \pm 0.1 \%$ & $13.2 \pm 1.2 \%$ \\
\hline Synchronized & $1.1 \pm 0.2 \%$ & $92.7 \pm 0.3 \%$ & $6.1 \pm 0.5 \%$ \\
\hline
\end{tabular}

Table 4-2: Characterization of cell cycle phase for representative samples of Control and Modified Double Thymidine Synchronized groups, presented as percentage of the population found in the specific cell cycle phase \pm the standard error of the mean. ( $n=3$ for both groups)

Table 4-2 shows a comparison of the percentage of the population found in specific points along the cell cycle for both control and synchronized groups. There was a demonstrable shift of the bulk of the population to the gated region for the $\mathrm{S}$ phase in terms of DNA content when subjected to the modified double thymidine block protocol. This was the highest demonstrated purity of a population in a single phase of all synchronization techniques attempted, and thus was selected as the optimal method of synchronization. 


\subsubsection{Viability of Encapsulation in Primary Articular Chondrocytes}

The trypan blue dye exclusion method was used to determine viability of recovered populations of primary articular chondrocytes recovered from different methods of hydrogel encapsulation.

\begin{tabular}{|l|c|}
\hline \multicolumn{1}{|c|}{ Encapsulation Technique } & $\begin{array}{c}\text { \% Viability of Recovered Population } \\
\text { (live cells/total) }\end{array}$ \\
\hline Agarose Cylinder & $6.1 \pm 1.4 \%$ \\
\hline Alginate Cylinder & $79.8 \pm 0.4 \%$ \\
\hline Alginate Bead & $87.9 \pm 0.4 \%$ \\
\hline
\end{tabular}

Table 4-3: Viabilities of recovered populations of primary articular chondrocytes, presented as a percentage of live cells to total cells counted \pm the standard error of the mean ( $n=7$ for all groups)

In Table 4-3, data on the viability of recovery from each encapsulation method was presented. The viability of recovery from agarose encapsulation was less than $10 \%$, which was significantly lower than both bead and cylindrical alginate encapsulation $(\mathrm{P}<0.05)$. Alginate bead encapsulation had a higher viability than than alginate cylinder encapsulation $(\mathrm{P}<0.05)$, and was also a more stable encapsulation when placed into culture.

\subsubsection{Tracking Cell Cycle Progression of Chondrocytes}

In order to assess quality and longevity of the synchronization process, the cell populations were assessed at 12 hour intervals for 48 hours after treatment. Cells were recovered from encapsulation via calcium chelation of the alginate constructs, and subjected to the same propidium iodide staining protocol. 


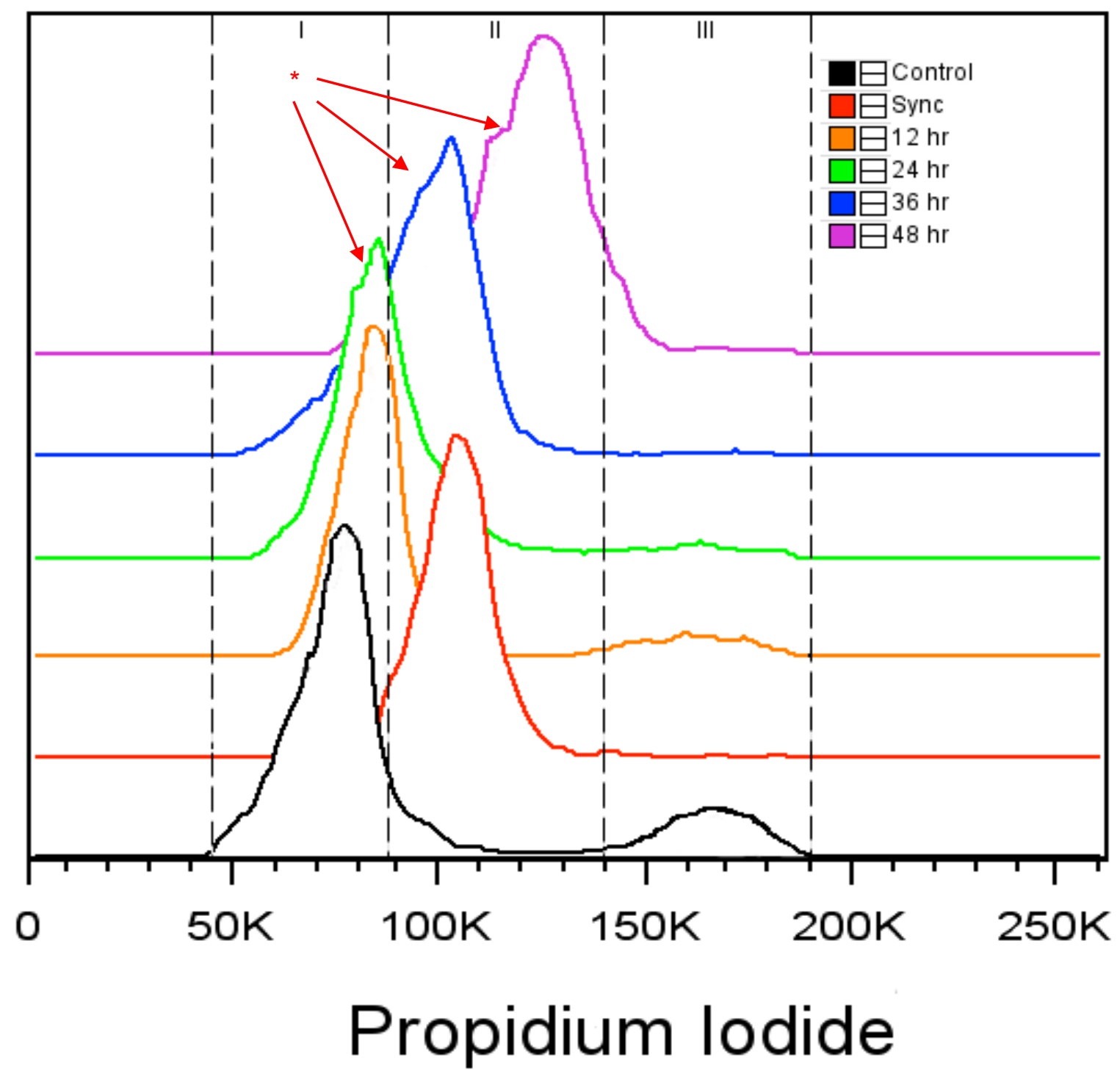

Figure 4-2: Representative overlay of histogram expression of DNA content for a Control population alongside a Synchronized population analyzed at 12-hour time points after synchronization, up to 48 hours. I) Staining region for G0-G1 phase II) Staining region for S phase III) Staining region for G2-M phase (* in the figure demonstrates the presence of a lagging population that represents an increasing asynchrony in the synchronized population starting at the 24 hour time point and progressing through the 48 hour time point).

Synchronization using the modified double thymidine block exhibited a demonstrable peak in the synthesis phase in terms of DNA content. As shown in Figure 4-2, at 12 hour increments, the population was shown to traverse through the cell cycle. Furthermore, the synchronization process was shown to lose its effect over time, with a noticeable trailing edge to the largest peak in each population that grew more pronounced at subsequent time points. 


\begin{tabular}{|l|c|c|c|}
\hline \multirow{2}{*}{ Sample } & \multicolumn{3}{|c|}{ \% Histology in Phase } \\
\cline { 2 - 4 } & $\mathbf{G}_{\mathbf{0}} / \mathbf{G}_{\mathbf{1}}$ & $\mathbf{S}$ & $\mathbf{G}_{2} / \mathbf{M}$ \\
\hline Control & $83.3 \pm 0.7 \%$ & $3.4 \pm 1.0 \%$ & $13.2 \pm 1.2 \%$ \\
\hline Sync & $1.1 \pm 0.2 \%$ & $92.7 \pm 0.3 \%$ & $6.1 \pm 0.5 \%$ \\
\hline $12 \mathrm{hr}$ & $61.1 \pm 0.3 \%$ & $26.6 \pm 0.2 \%$ & $12.3 \pm 0.4 \%$ \\
\hline $24 \mathrm{hr}$ & $54.9 \pm 0.1 \%$ & $38.1 \pm 0.5 \%$ & $6.9 \pm 0.4 \%$ \\
\hline $36 \mathrm{hr}$ & $24.7 \pm 0.3 \%$ & $72.8 \pm 0.5 \%$ & $2.5 \pm 0.1 \%$ \\
\hline $48 \mathrm{hr}$ & $2.9 \pm 0.5 \%$ & $81.6 \pm 3.0 \%$ & $15.4 \pm 2.5 \%$ \\
\hline
\end{tabular}

Table 4-4: Characterization of cell cycle phase for representative samples of a Control population alongside a Modified Double Thymidine Synchronized population tracked at 12-hour time points for 48 hours, presented as percentage of the population found within the specific cell cycle phase \pm the standard error of the mean ( $n=3$ for control and synchronized groups, $n=2$ for all subsequent time points).

Tracking of the cell cycle phase was quantified in Table 4-4, which provides the percentage of cells found in each phase of the cell cycle. It was observed that the highly synchronized $(92.7 \pm 0.3 \%)$ peak in the S phase did not maintain synchronous progression through the cell cycle over time, with a visible trailing peak of cells in the 24 hour time point that did not progress through the cell cycle at the same rate. This peak of trailing cells behind the larger, more synchronized peak of cells, became visibly larger at subsequent time points, evidenced by the broadening width of each histogram. 


\subsection{Effects of Optimized Synchronization on Chondrogenesis}

After harvest from culture at 2-week and 4-week time points, the biochemical composition and structure of each construct were analyzed. Comparisons of the DNA content, sulfated glycosaminoglycan content, and collagen content were conducted as primary markers of cartilage tissue synthesis.

Chondrogenesis of these samples was also compared through the histological and immunohistochemical assessment of glycosaminoglycans (safranin-O), general collagen (sirius red), and collagen types I and II.

\subsubsection{Effect of Optimized Synchronization on DNA Content}

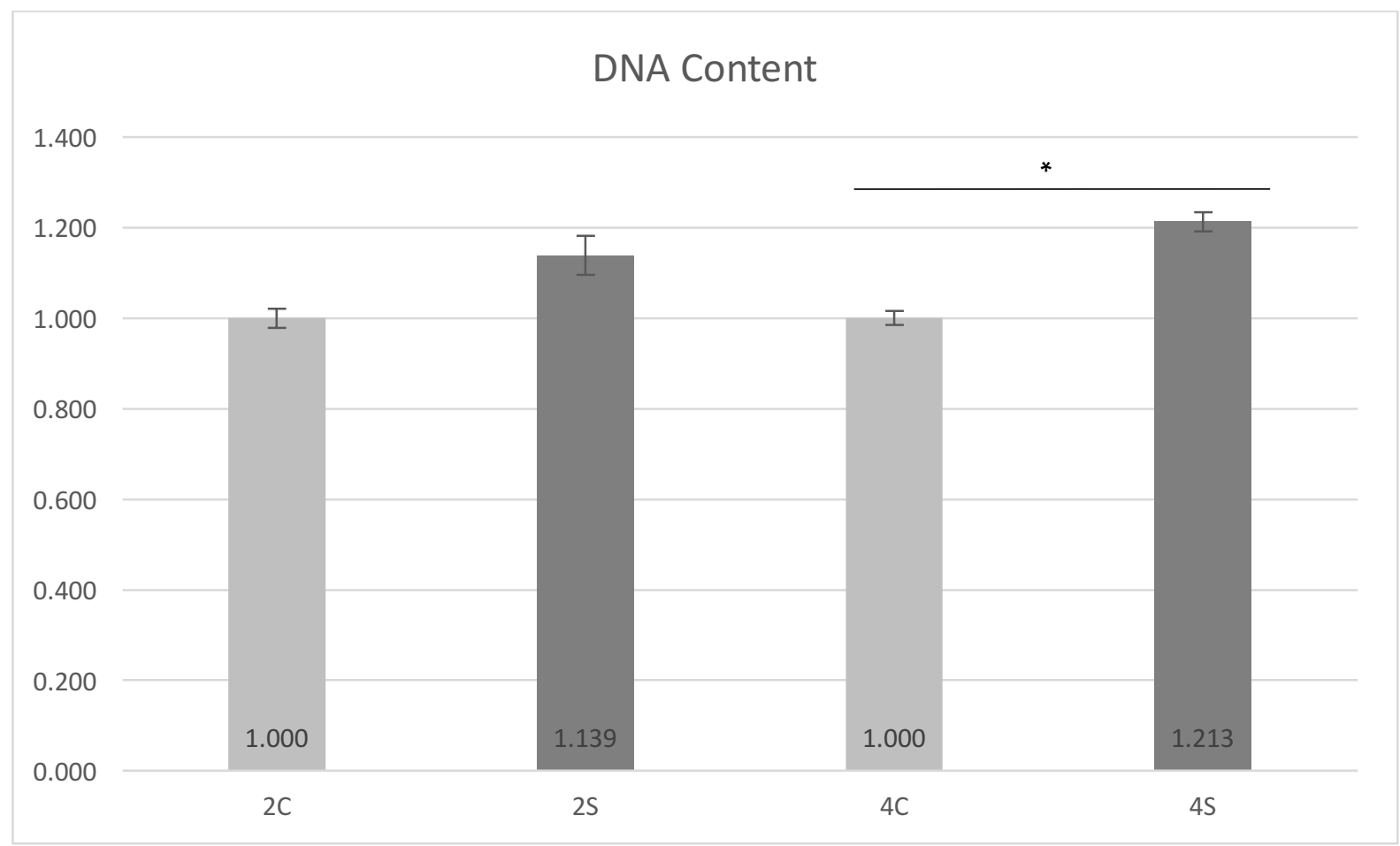

Figure 4-3: DNA content normalized to the content of the control sample each time point for 2C (twoweek control), $2 S$ (two-week synchronized), 4C (four-week control), and $4 S$ (four-week synchronized) groups. Error bars display mean \pm the standard error of the mean $(n=6, *$ denotes $P<0.05$ when compared to control).

Quantification of DNA content through the QuantIT PicoGreen DNA binding dye provided a measure of the cellularity of samples in each group. There was a visible increase in DNA content of synchronized constructs at both the 2-week and 4-week time points when compared to their respective controls. Due to the high variance of the DNA content of the synchronized constructs at two weeks, they 
failed to register a significant difference compared to the 2-week controls. A $21 \%$ increase in the DNA content of the synchronized group compared to the controls was detected at 4 weeks that registered as significant $(\mathrm{P}<0.05)$. In order to further assess the effects of synchronization on DNA content over time, the DNA content was presented as 4-week groups normalized to their 2 week counterparts, shown in Figure 4-4.

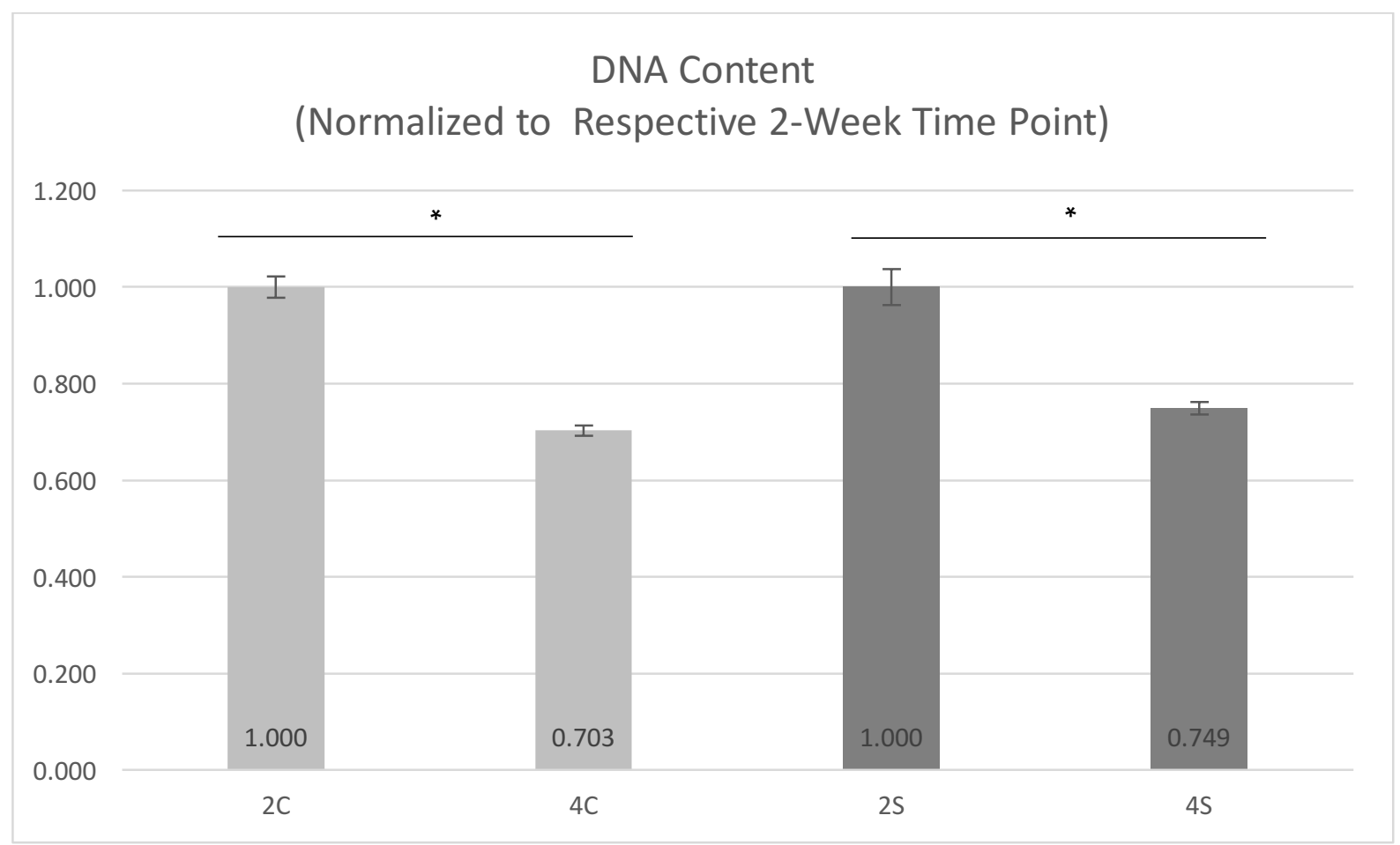

Figure 4-4: DNA content for 2C (two-week control), 2S (two-week synchronized), 4C (four-week control), and $4 S$ (four-week synchronized) groups, normalized to the respective sample at 2 weeks (i.e. $4 S$ to $2 S$ and $4 C$ to $2 C)$. Error bars display mean \pm the standard error of the mean $(n=6, *$ denotes $P<0.05$ when compared to respective 2-week time points).

For both control and synchronized populations, 4-week samples that were normalized to their respective 2-week time point exhibited a significant decrease in DNA. The control population at 4 weeks demonstrated a near 30\% decrease in DNA content compared to its 2-week time point $(\mathrm{P}<0.05)$, while the synchronized population at 4 weeks demonstrated an approximate $25 \%$ decrease in DNA content compared to its 2 week time point $(\mathrm{P}<0.05)$. 


\subsubsection{Effect of Optimized Synchronization on Proteoglycan Content}

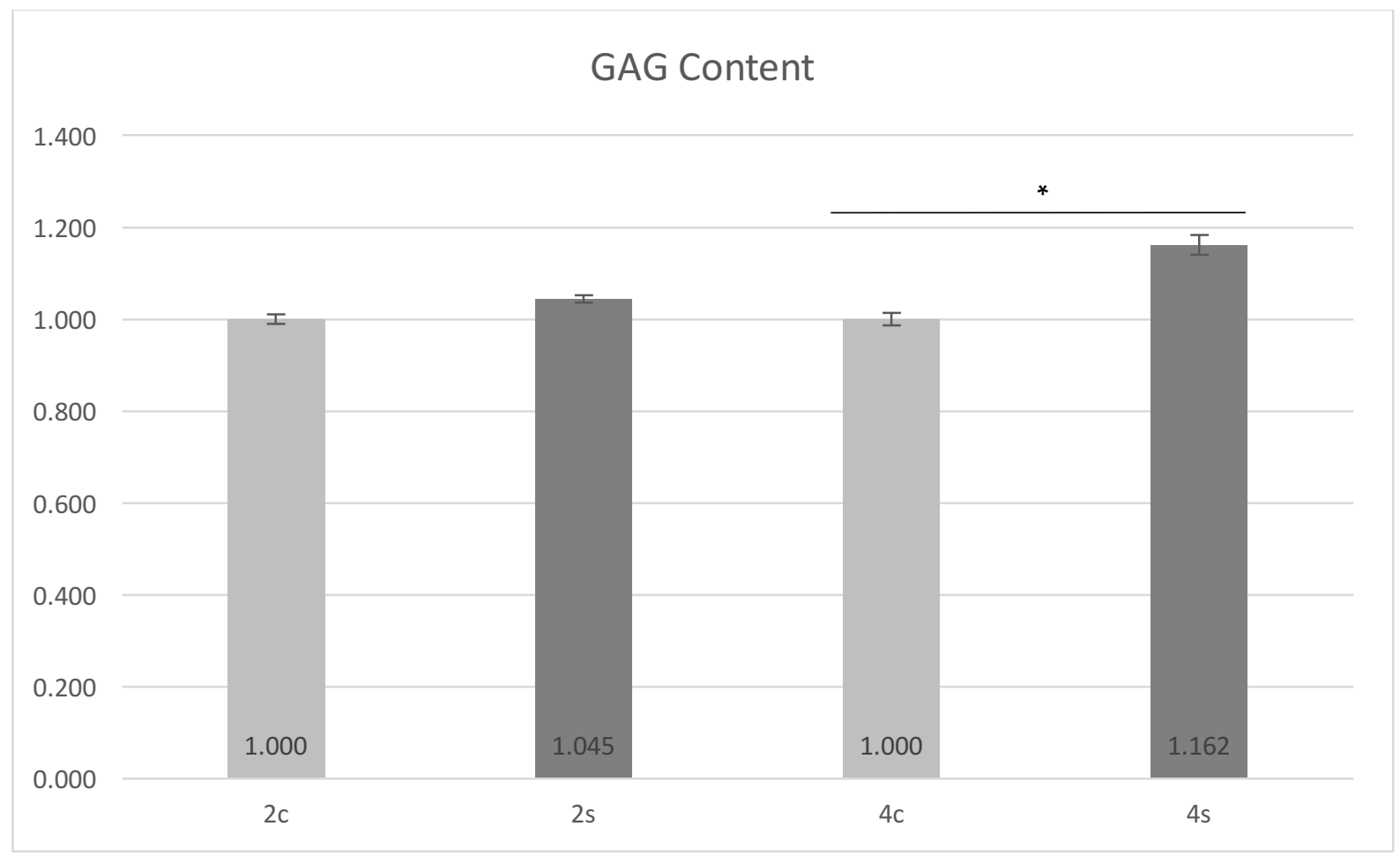

Figure 4-5: Sulfated glycosaminoglycan content normalized to the content of the control sample at each time point for 2C (two-week control), $2 S$ (two-week synchronized), 4C (four-week control), and $4 S$ (fourweek synchronized) groups. Error bars display mean \pm the standard error of the mean $(n=6$, * denotes $P$ $<0.05$ when compared to controls).

The accumulation of sulfated glycosaminoglycans in the extracellular matrix was quantified via the DMMB-binding assay, shown above in Figure 4-5. In terms of sulfated glycosaminoglycan content, the synchronized group showed no significant increase compared to controls at the 2-week time point. At the 4-week time point, the synchronized sample had accumulated a significant amount more sulfated glycosaminoglycan molecules compared to the control group $(\mathrm{P}<0.05)$. Through normalization it was determined that at 4 weeks, the synchronized group exhibited over $16 \%$ increase in sulfated glycosaminoglycan content compared to controls. There was a visible increase in the amount of sulfated glycosaminoglycan content over time, as shown by normalizations of the GAG content of 4 week synchronized and control groups to their respective 2-week time points in Figure 4-6. 


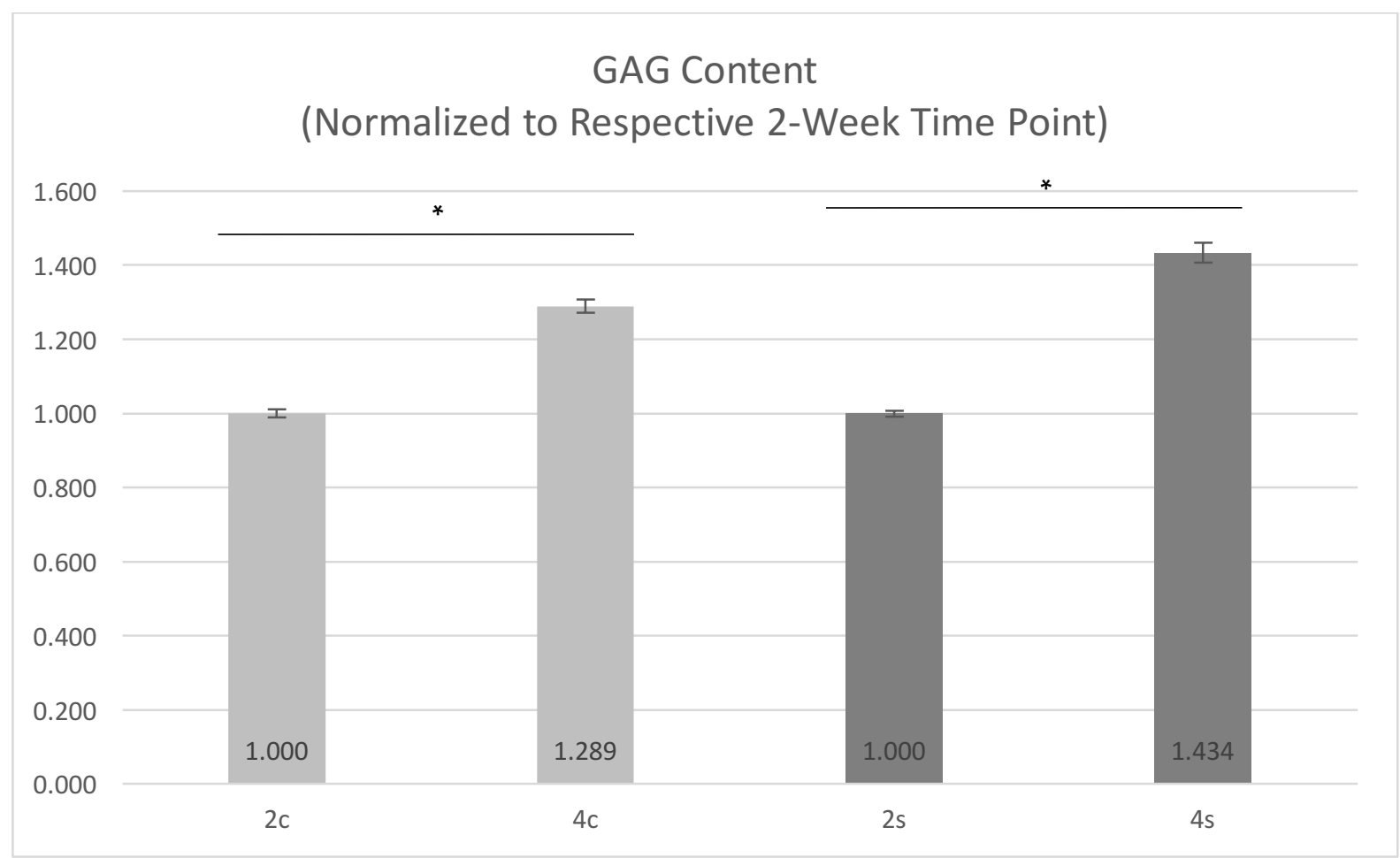

Figure 4-6: Sulfated glycosaminoglycan content for 2C (two-week control), 2S (two-week synchronized), $4 C$ (four-week control), and $4 S$ (four-week synchronized) groups, normalized to the respective sample at 2 weeks (i.e. $4 S$ to $2 S$ and $4 C$ to $2 C$ ). Error bars display mean \pm the standard error of the mean ( $n=6, *$ denotes $P<0.05$ when compared to respective 2-week time points).

Figure 4-6 displays quantification of both the control and synchronized 4-week groups normalized to their respective 2 -week time points. For both control and synchronized populations, 4 week samples exhibited a significant increase in sulfated glycosaminoglycan content. The 4-week control group demonstrated a $28.9 \%$ increase in sulfated glycosaminoglycan content compared to its 2 -week time point $(\mathrm{P}<0.05)$, while the 4-week synchronized group exhibited a $43.4 \%$ increase in sulfated glycosaminoglycan content compared to its 2 week time point $(\mathrm{P}<0.05)$. 


\section{GAG/DNA Ratio}

\subsection{0}

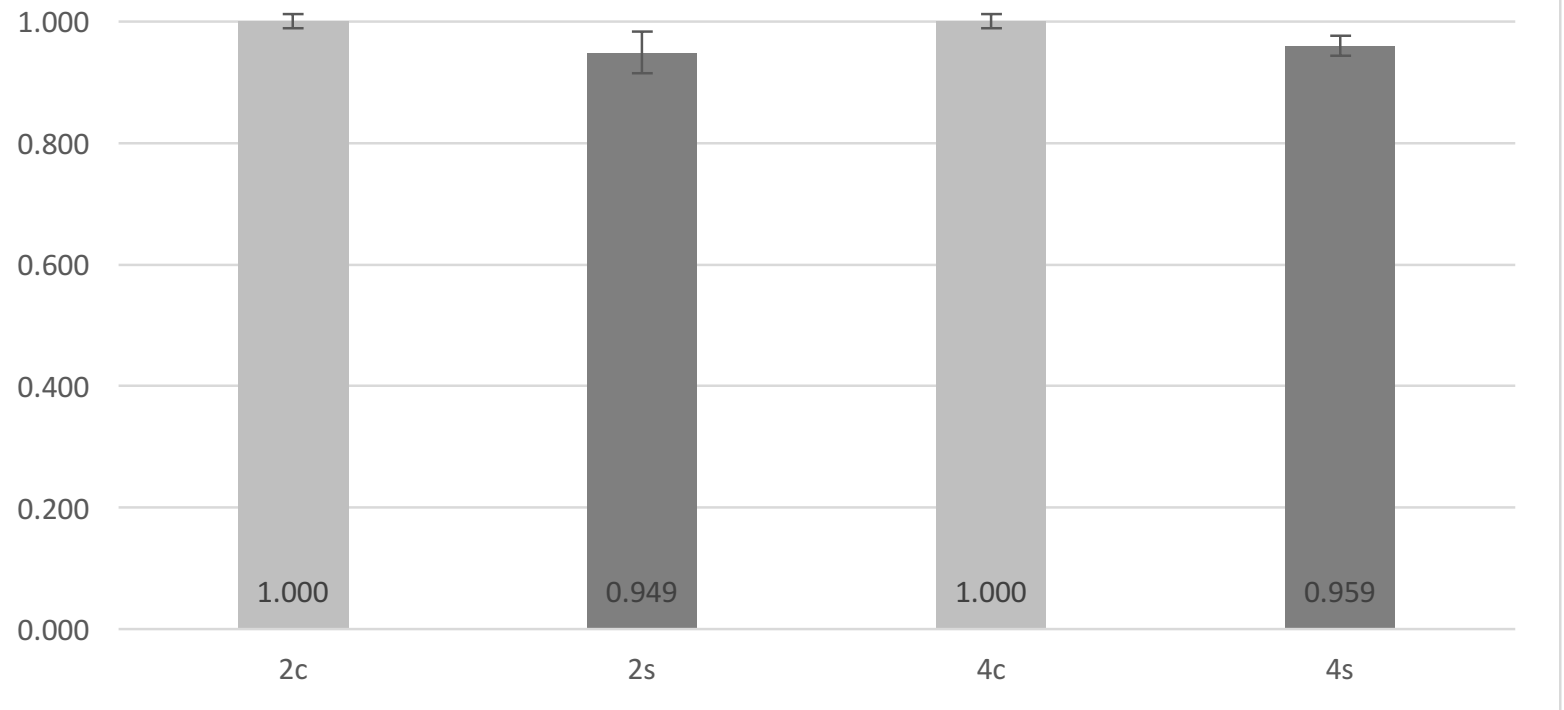

Figure 4-7: Ratio of Sulfated Glycosaminoglycan mass to DNA mass normalized to control samples at each time point for $2 C$ (two-week control), $2 S$ (two-week synchronized), $4 C$ (four-week control), and $4 S$ (four-week synchronized) groups. Error bars display mean \pm the standard error of the mean $(n=6)$.

The ratio of sulfated glycosaminoglycan content to DNA content provided an index of the amount of sulfated glycosaminoglycan produced per cell. This index was presented normalized to the control group at each time point, as shown in in Figure 4-7. At both 2 weeks and 4 weeks, synchronized groups demonstrated no significant changes in this ratio compared to their respective controls. A measure of the change of this ratio over time was shown by normalizing the 4-week synchronized and control groups to their respective 2-week time points, as shown in Figure 4-8. 


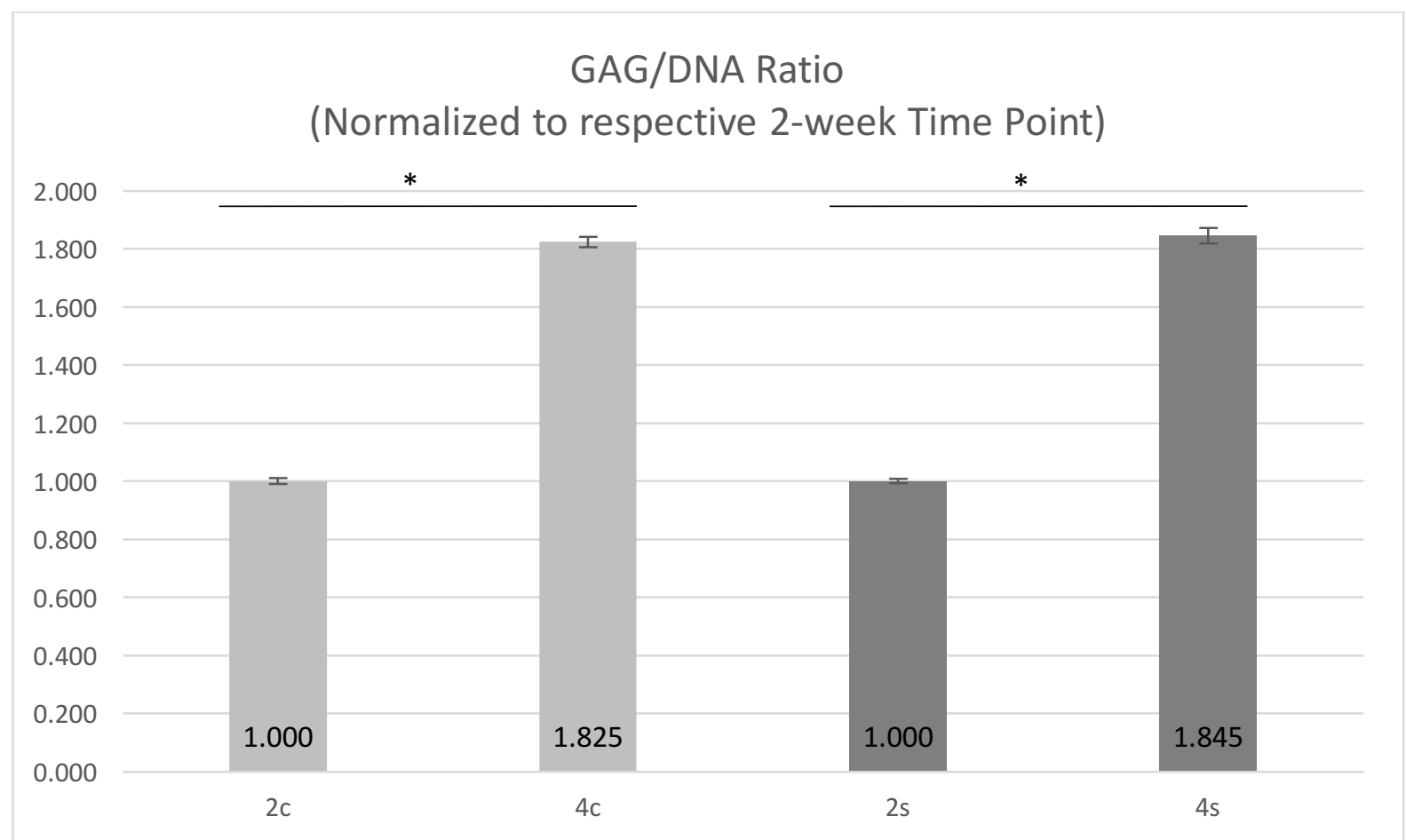

Figure 4-8: Ratio of Sulfated Glycosaminoglycan mass to DNA mass for 2c (two-week control), $2 S$ (twoweek synchronized), $4 C$ (four-week control), and $4 S$ (four-week synchronized) groups, normalized to the respective sample at 2 weeks (i.e. $4 S$ to $2 S$ and $4 C$ to $2 C$ ). Error bars display mean \pm the standard error of the mean ( $n=6, *$ denotes $P<0.05$ when compared to respective 2 -week time points).

Normalizing the four-week control and synchronized groups to their two week counterparts yielded information about the amount of sulfated glycosaminoglycans produced on a per cell basis over time. This data is presented in Figure 4-8. Both control and synchronized groups exhibited over 80\% increases in the GAG/DNA ratio $(\mathrm{P}<0.05)$, indicating that at four weeks, the cells of both control and synchronized groups had produced significantly more GAG on a per cell basis compared to the constructs at two weeks, or the amount of accumulated proteoglycan content increased concurrently with a significant decrease in DNA content. 


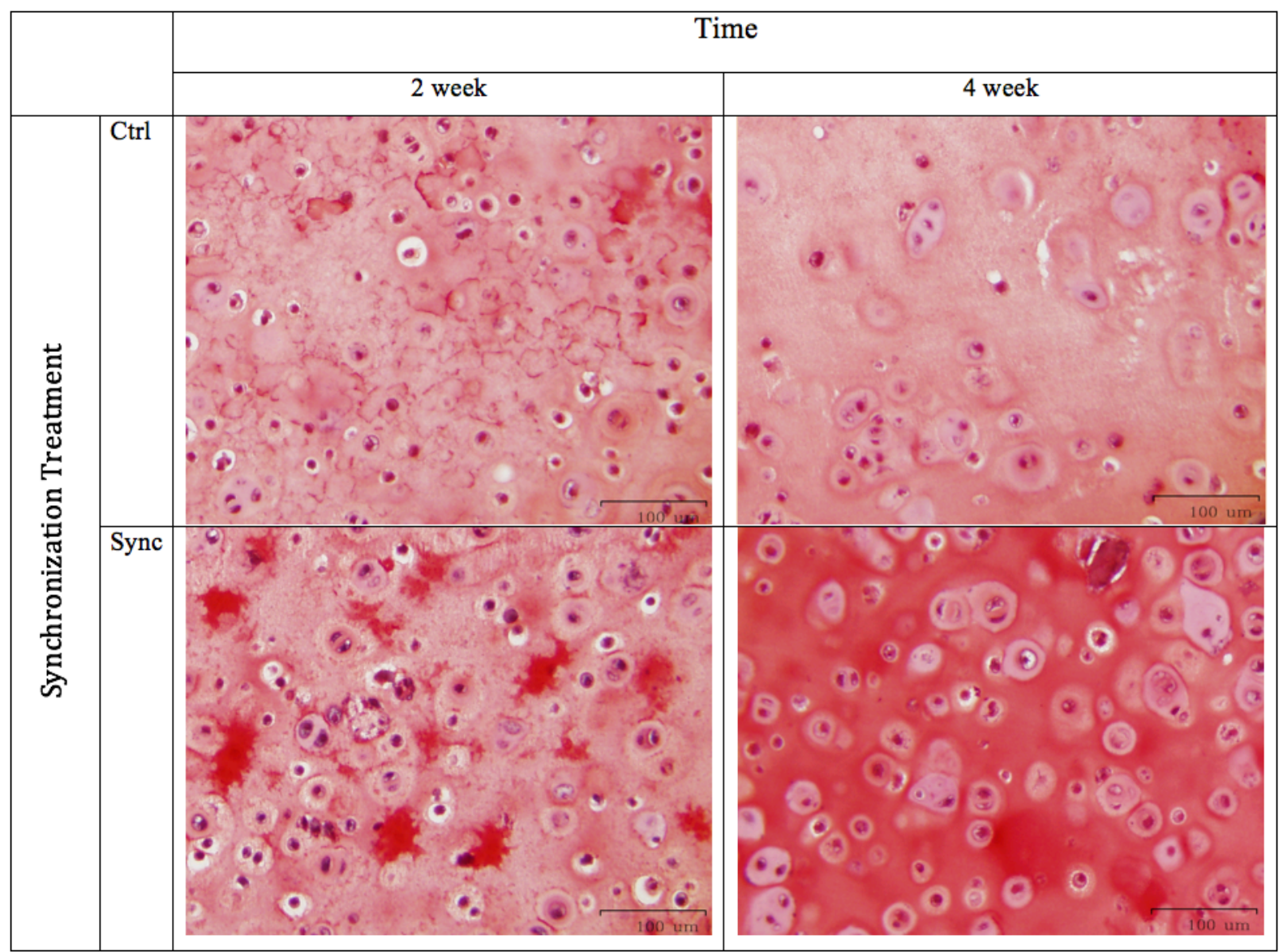

Figure 4-9: Representative samples for matrix synthesis in chondrocyte embedded alginate constructs as exhibited by Safranin Oxide detection, which stains cartilage and mucin red, nuclei black, and background blue.

Figure 4-9 demonstrates quantitative analysis of matrix synthesis in processed tissue sections of the primary articular chondrocyte-seeded alginate beads. At two weeks, the synchronized group appeared to accumulate more glycosaminoglycans, with pockets of inter-territorial cartilage staining that were visibly more obvious compared to controls. There was already detectable presence of doublets with surrounding extracellular matrix that was visibly more apparent, and the constructs appeared more cellular. At four weeks, the control group had developed formation of doublets and lacunae. The synchronized group appeared to be more cellular, with the staining of territorial and inter-territorial glycosaminoglycans appearing much more distinct. 


\subsubsection{Effect of Optimized Synchronization on Collagen Content}

Collagen content of each construct was quantified using the hydroxyproline assay. The results are shown below in Figure 4-10, presented as synchronized groups normalized to the controls at 2-week and 4-week time points respectively.

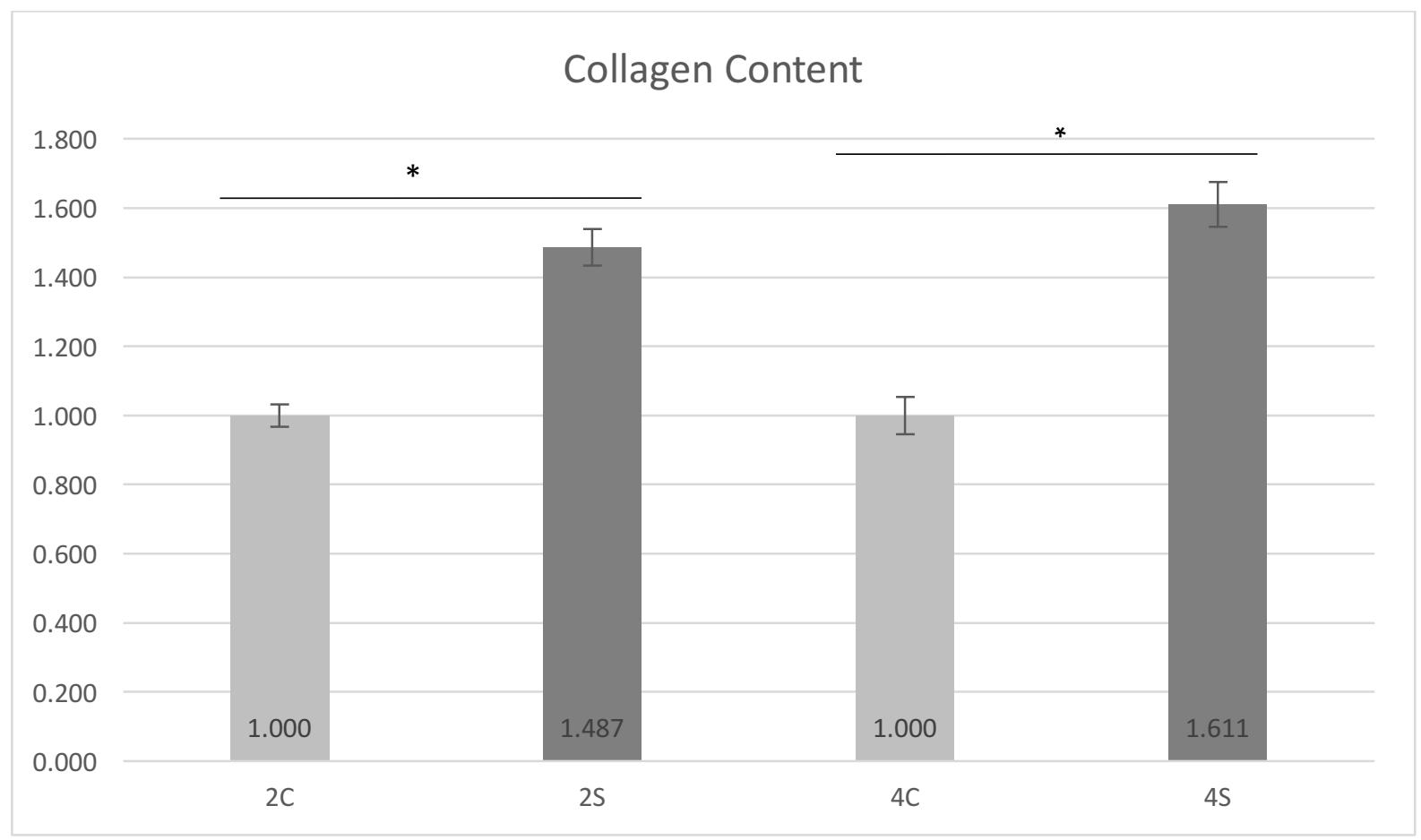

Figure 4-10: Collagen content normalized to the content of the control sample at each time point for $2 \mathrm{C}$ (two-week control), 2S (two-week synchronized), 4C (four-week control), and $4 S$ (four-week synchronized) groups. Error bars display mean \pm the standard error of the mean $(n=6, *$ denotes $P<$ 0.05 when compared to controls).

The 2 week synchronized group normalized to its control group exhibited a significant $48.7 \%$ increase over controls in terms of accumulated collagen $(\mathrm{P}<0.05)$, as shown above in Figure 4-10. At the 4-week time point, when normalized to the 4-week controls, the synchronized group displayed a significant $61.1 \%$ increase in collagen content $(\mathrm{P}<0.05)$. In order to further assess the effects of synchronization on DNA content over time, the collagen content was presented as 4-week groups normalized to their 2-week counterparts, shown in Figure 4-11. 


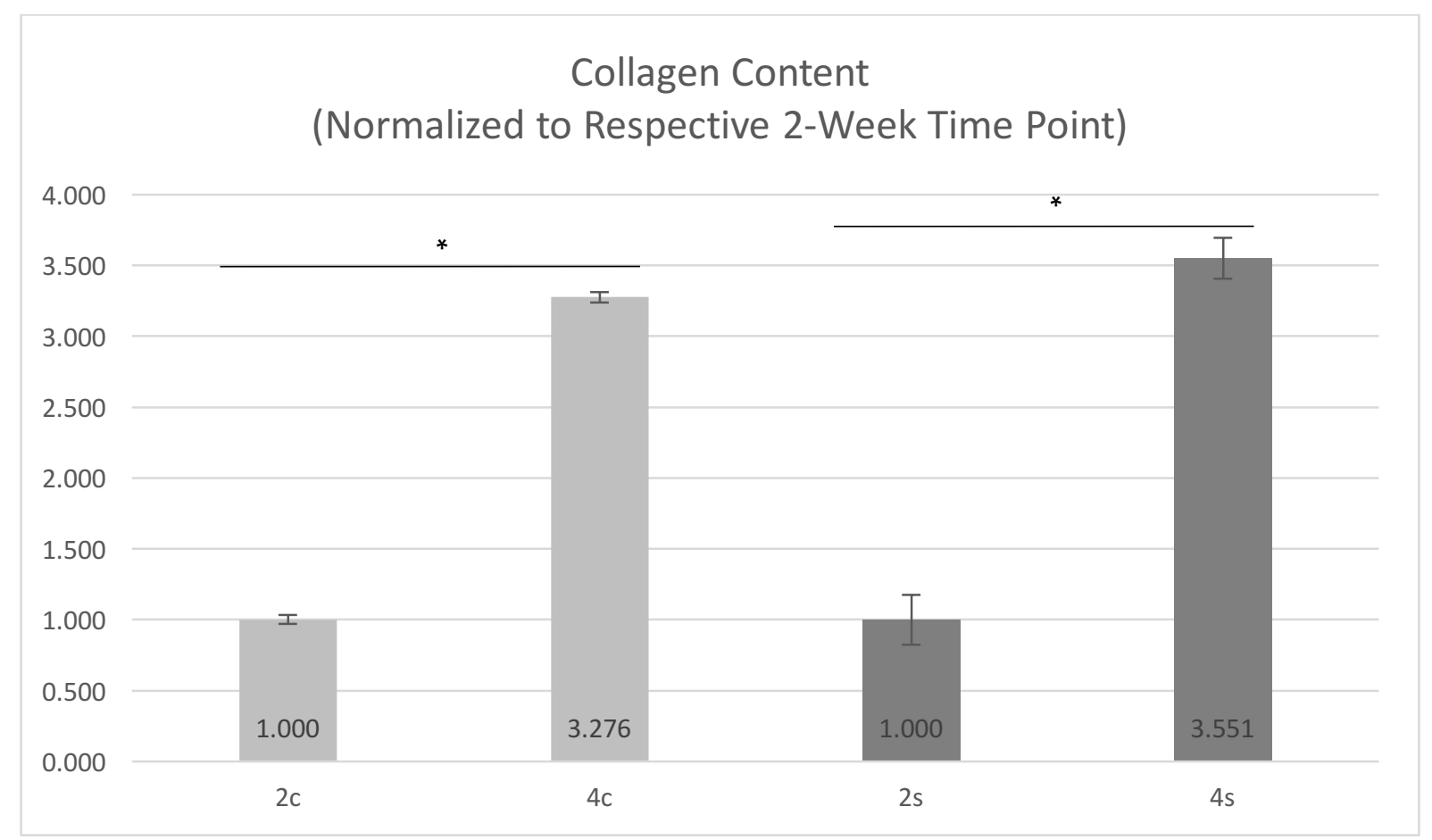

Figure 4-11: Collagen content for 2C (two-week control), 2S (two-week synchronized), 4C (four-week control), and $4 S$ (four-week synchronized) groups, normalized to the respective sample at 2 weeks (i.e. $4 S$ to $2 S$ and $4 C$ to $2 C)$. Error bars display mean \pm the standard error of the mean $(n=6, *$ denotes $P<0.05$ when compared to respective 2-week time points).

When normalized to their respective two week time points (shown in Figure 4-11), a significant increase in collagen content over time was demonstrated in both the control group (over 3.2-fold increase, $\mathrm{P}<0.05$ ) and synchronized group (over 3.5-fold increase, $\mathrm{P}<0.05$ ), indicating both saw a significant increase in the amount of collagen synthesized per cell over time, or the accumulation of collagen increased concurrently with a significant decrease in DNA content. 


\section{Collagen/DNA Ratio}

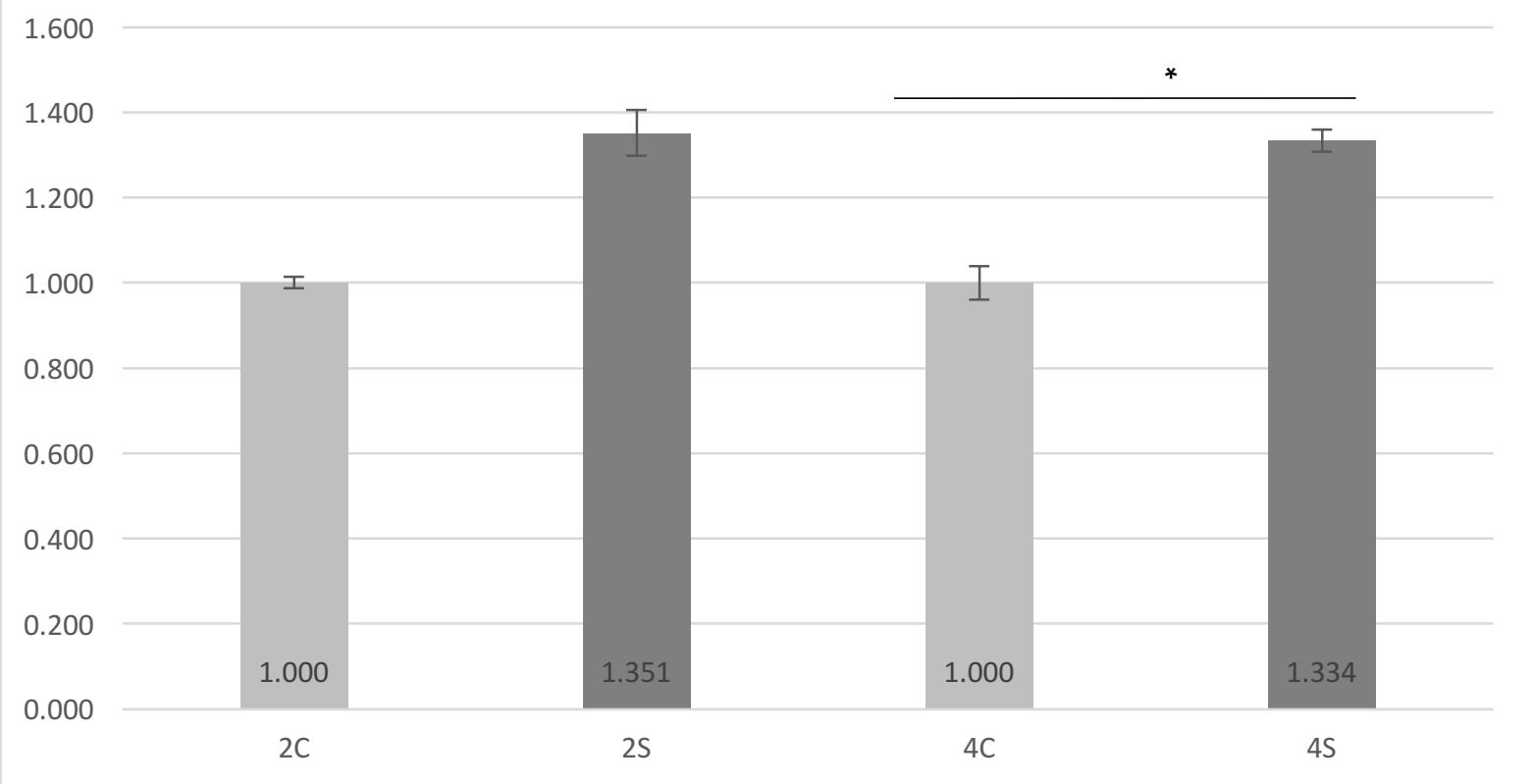

Figure 4-12: Ratio of Collagen mass to DNA mass normalized to control samples at each time point for $2 C$ (two-week control), 2S (two-week synchronized), 4C (four-week control), and $4 S$ (four-week synchronized) groups. Error bars display mean \pm the standard error of the mean $(n=6, *$ denotes $P<$ 0.05 when compared to controls).

The ratio of collagen to DNA provides an index of the amount of collagen synthesized per cell. At the 2-week time point, an apparent $35.1 \%$ increase in the collagen/DNA ratio in the synchronized group failed to register as significant compared to the control group due to the high variance of the synchronized sample. At the 4-week time point, the synchronized group exhibited a significant $33.4 \%$ increase over the control group $(\mathrm{P}<0.05)$. A measure of the change of this ratio over time was shown by normalizing the 4-week synchronized and control groups to their respective 2- week time points, as shown in Figure 4-13. 


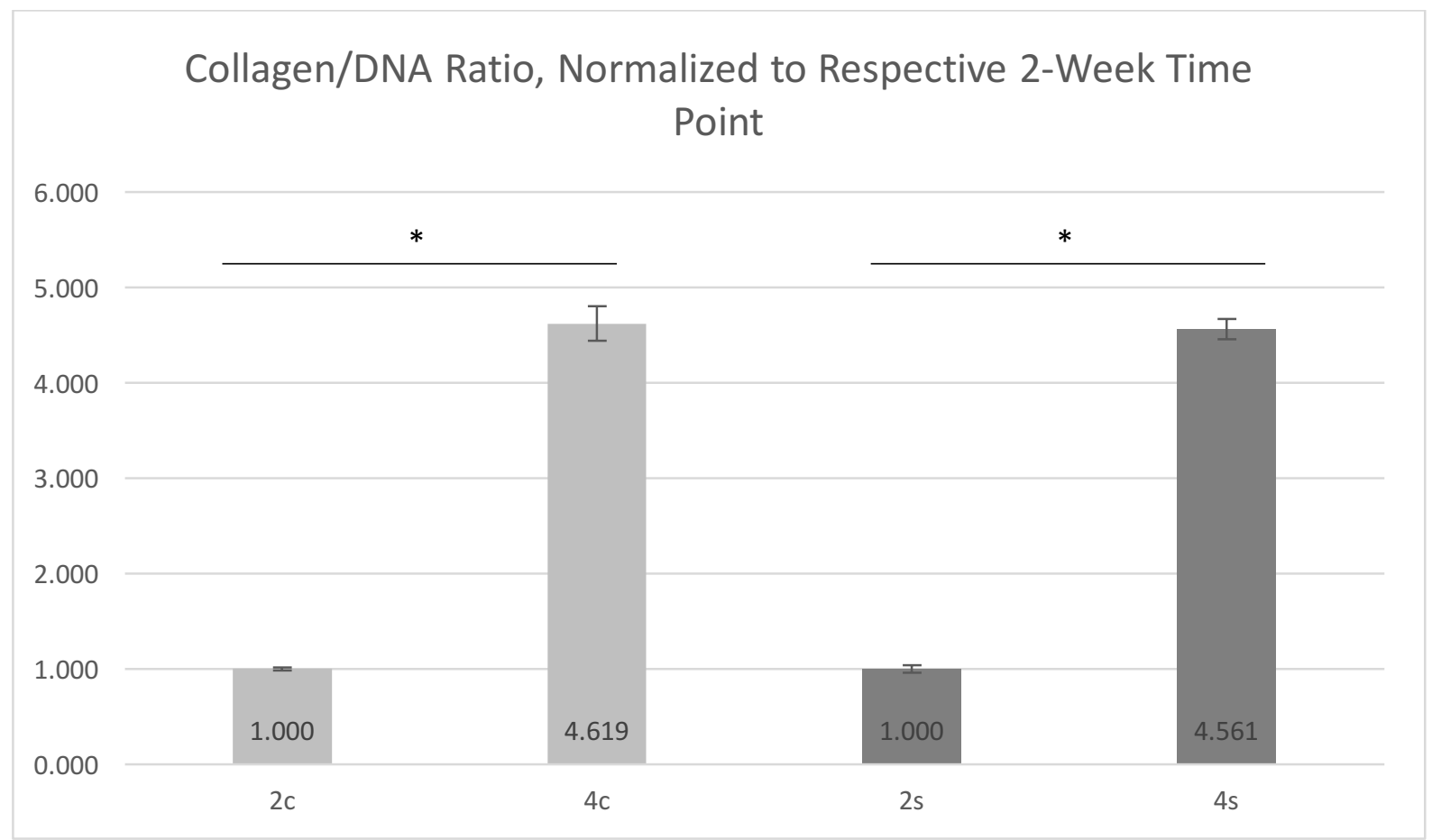

Figure 4-13: Ratio of Collagen mass to DNA mass for 2C (two-week control), $2 S$ (two-week synchronized), $4 C$ (four-week control), and $4 S$ (four-week synchronized) groups, normalized to the respective sample at 2 weeks (i.e. $4 S$ to $2 S$ and $4 C$ to $2 C$ ). Error bars display mean \pm the standard error of the mean ( $n=6, *$ denotes $P<0.05$ when compared to respective 2 -week time points).

A comparison of the collagen/DNA ratio in 4-week synchronized and control groups compared to their respective 2-week time points is shown above in Figure 4-13. In both the control and synchronized groups, an over 4.5-fold increase in 4-week time points was detected $(\mathrm{P}<0.05)$, which is logical given the increase in accumulated collagen content and the decrease in DNA content at four weeks in culture. 


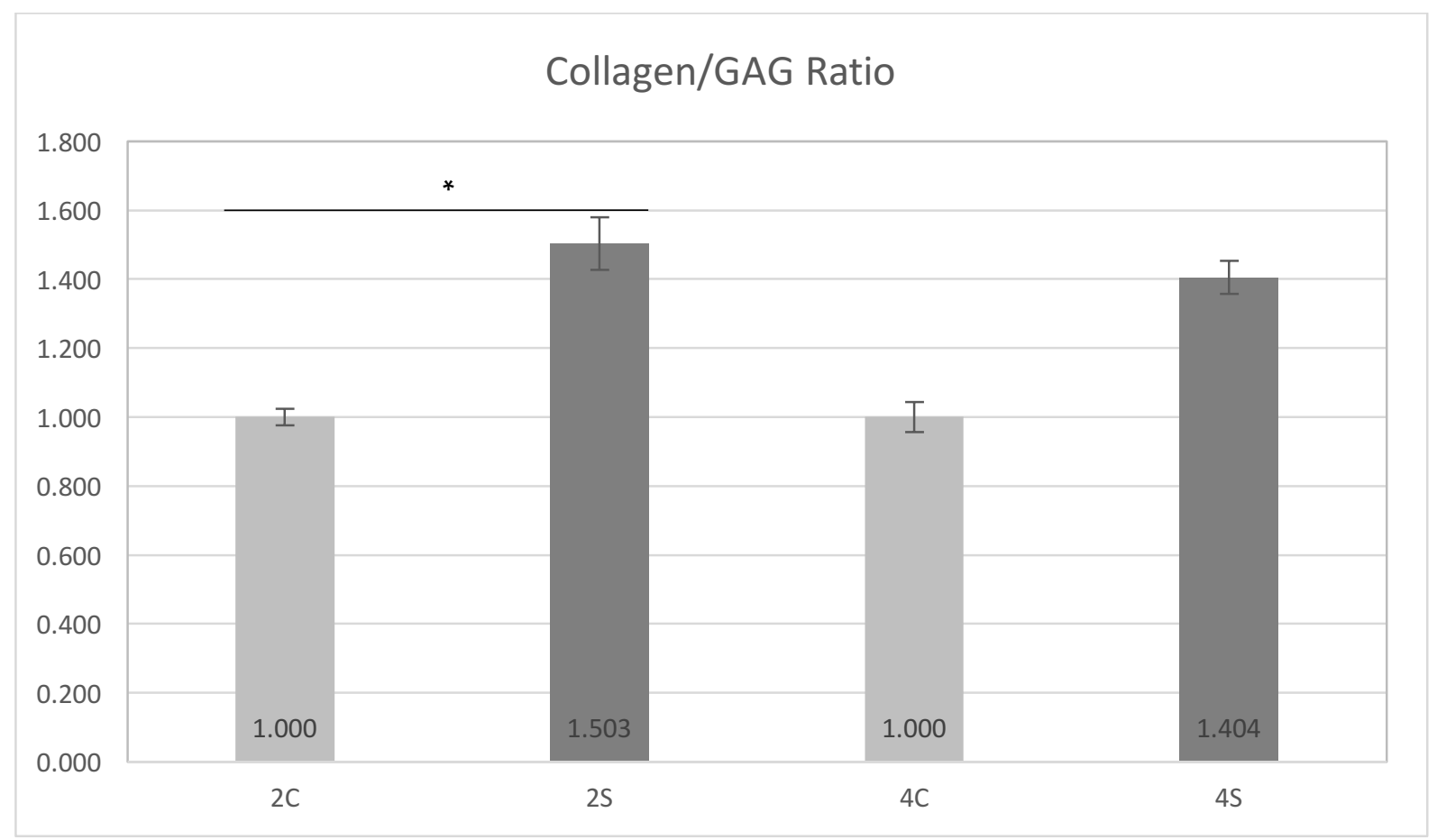

Figure 4-14: Ratio of Collagen mass to GAG mass normalized to control samples at each time point for $2 C$ (two-week control), 2S (two-week synchronized), 4C (four-week control), and $4 S$ (four-week synchronized) groups. Error bars display mean \pm the standard error of the mean $(n=6, *$ denotes $P<$ 0.05 when compared to controls).

The collagen/glycosaminoglycan ratio is used as an index of chondrogenic growth, and is presented as synchronized groups normalized to their respective controls at both 2-week and 4-week time points in Figure 4-14. At the 2-week time point, the synchronized group exhibited a significant 1.5-fold increase in this ratio $(\mathrm{P}<0.05)$, while at the 4 -week time point the 1.4 -fold increase in the synchronized group failed to register as significant compared to controls. A measure of the change of this ratio over time was shown by normalizing the 4-week synchronized and control groups to their respective 2-week time points, as shown in Figure 4-15. 


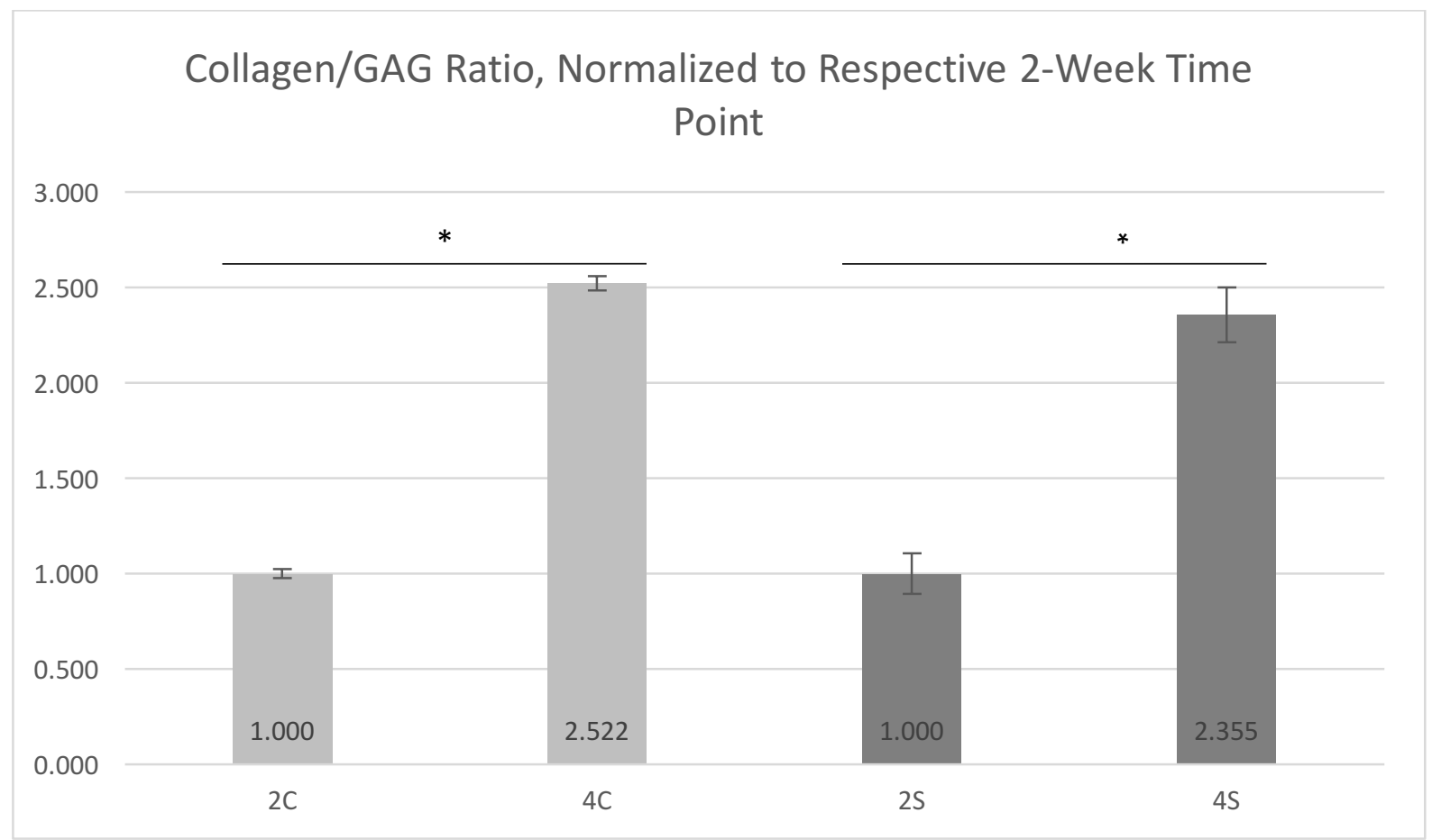

Figure 4-15: Ratio of Collagen mass to GAG mass for 2C (two-week control), $2 S$ (two-week synchronized), 4C (four-week control), and $4 S$ (four-week synchronized) groups, normalized to the respective sample at 2 weeks (i.e. $4 S$ to $2 S$ and $4 C$ to $2 C$ ). Error bars display mean \pm the standard error of the mean ( $n=6$, * denotes $P<0.05$ when compared to respective 2 -week time points).

A comparison of the collagen/GAG ratio in 4-week synchronized and control groups compared to their 2-week time points is shown above in Figure 4-15. An over 2.5-fold increase in the 4-week control group compared to its 2-week counterpart was determined to be significant $(\mathrm{P}<0.05)$. Similarly, an over 2.3-fold increase in the 4-week synchronized group compared to its 2-week counterpart was determined to be significant $(\mathrm{P}<0.05)$. 


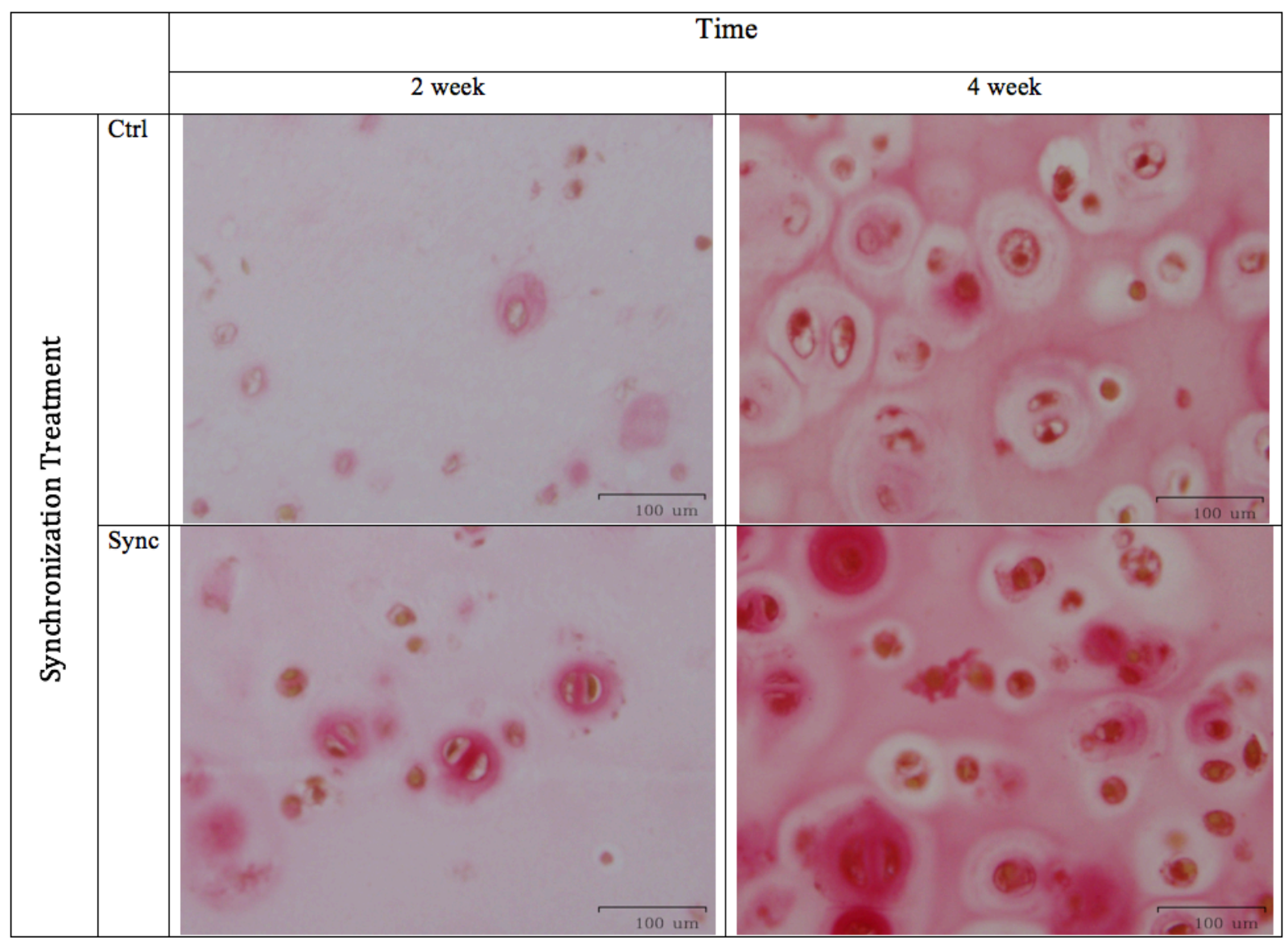

Figure 4-16: Representative samples for chondrogenesis in chondrocyte embedded alginate constructs as exhibited by Sirius Red detection, which stains collagen red and background yellow.

At two weeks, the synchronized group already appeared to accumulate more collagen, with more intense pockets of staining visible in the territorial and inter-territorial matrix of the synchronized group compared to controls as seen in Figure 4-16. There was already a visible presence of doublets surrounded by cartilaginous matrix and the synchronized constructs appeared more cellular than control groups.

At four weeks, the control group had developed formation of doublets surrounded by cartilaginous matrix, and lacunae were apparent. The presence of inter-territorial collagen was detected in both the control and synchronized groups, and appeared more intense in the synchronized group. The synchronized group also appeared to be more cellular, with the chondrocytes territorial and interterritorial matrix appearing much more distinct. 


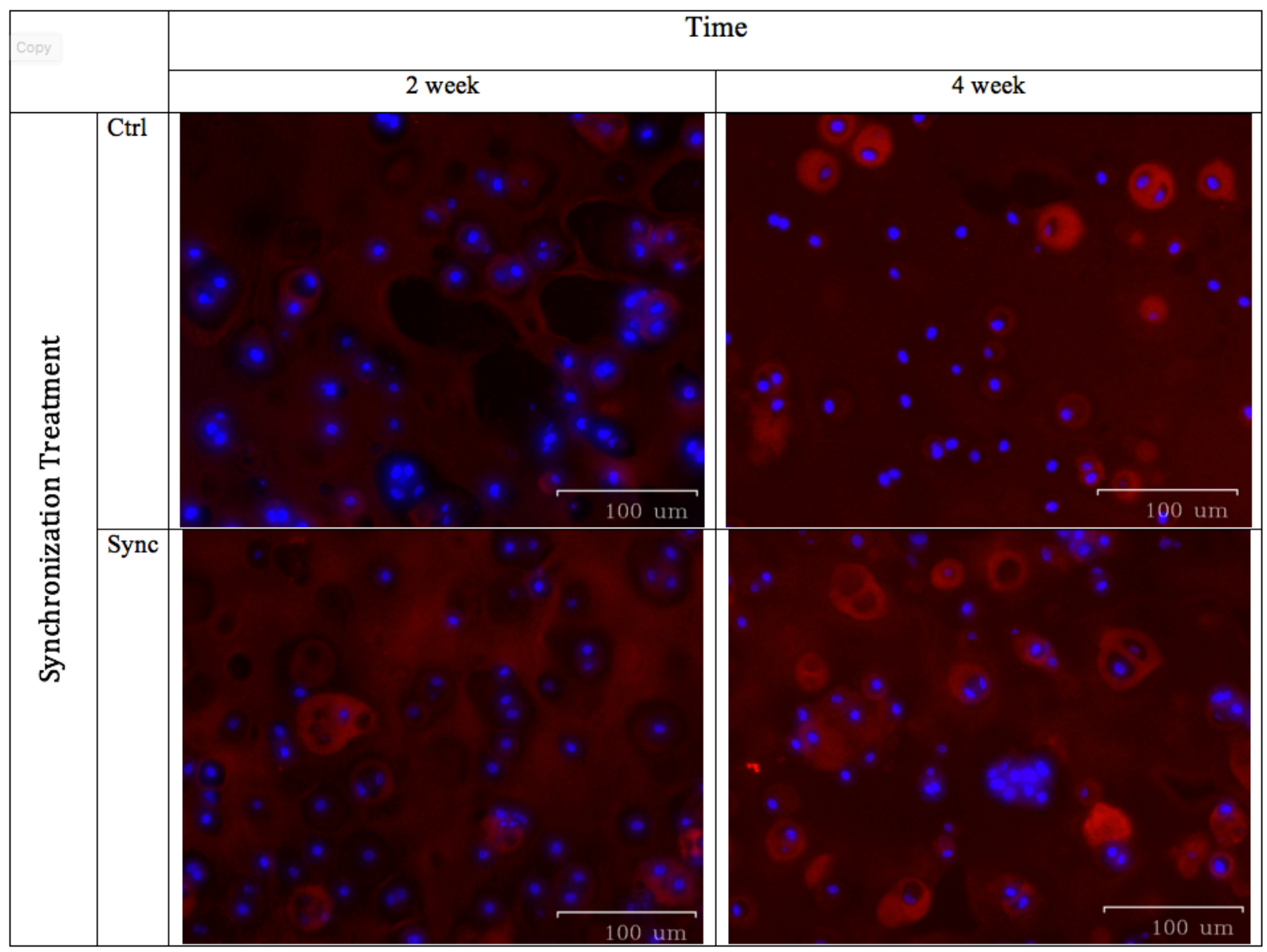

Figure 4-17: Representative samples of immunohistochemical detection of collagen II in chondrocyte embedded alginate constructs. Collagen II is bound to a secondary antibody tagged with AlexaFluor 647 which fluoresces red, while nuclei are stained with DAPI which fluoresces blue.

In Figure 4-17, the fluorescent collagen II staining of sections of synchronized and control constructs at both 2-week and 4-week time-points is displayed. At two weeks in culture, the synchronized group appeared more developed from a chondrogenic perspective, with pockets of collagen II staining in the cytoplasm that were visibly more intense compared to controls, which fluoresced less intensely around the nuclei. Formation of doublets surrounded by matrix rich in type II collagen was visible, and the territorial and matrix exhibited a stronger signal for collagen II compared to controls. At four weeks, the control group had developed more territorial matrix around the chondrocytes, which fluoresced more intensely. The synchronized group appeared more cellular than the control group, with a stronger DAPI signal observed, and also exhibited a much stronger collagen II signal within the distant regions from the cells. 
In control and synchronized groups at both 2-week and 4-week time points, little or no fluorescent signal for collagen I staining was visible in the processed tissue sections, as shown below in Figure 4-18. Thus, both synchronized and untreated cultures of alginate-encapsulated chondrocytes appeared to maintain their chondrogenic phenotype throughout the 4-week culture period.

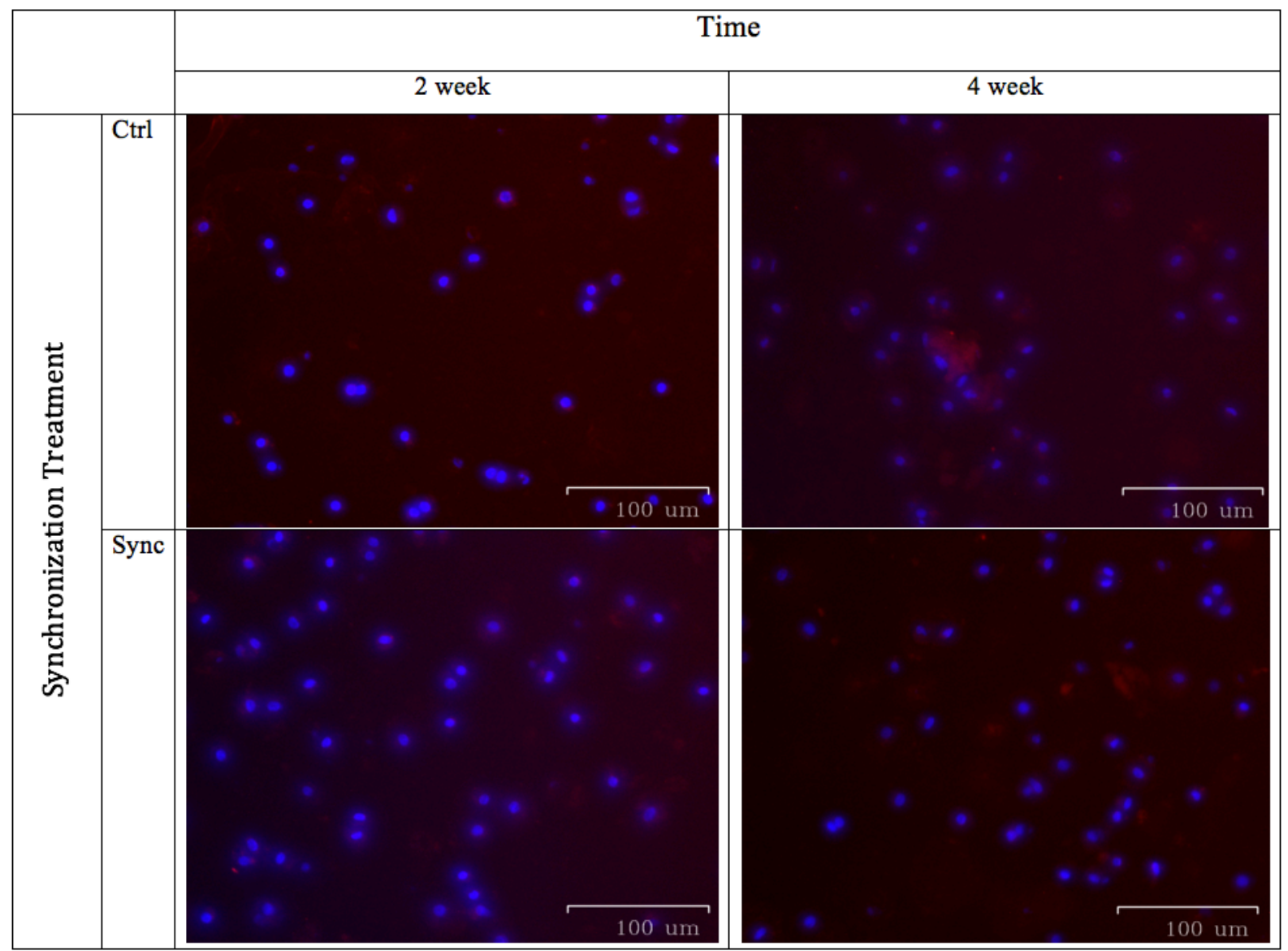

Figure 4-18: Representative samples of immunohistochemical detection of collagen I in chondrocyte embedded alginate constructs. Collagen I is bound to a secondary antibody tagged with AlexaFluor 647 which fluoresces red, while nuclei are stained with DAPI which fluoresces blue. 


\section{Chapter 5 Discussion}

\subsection{General Discussion}

\subsubsection{Overview of Research}

The objectives of this research were to develop and optimize a method for synchronizing the cell cycle phase of primary articular chondrocytes and to determine the effects

of cell cycle synchronization on growth characteristics of these cells in long term culture in vitro. It was hypothesized that cell cycle synchronization would alter the ability of primary articular chondrocytes to synthesize cartilaginous extracellular matrix based on previous research which indicates a similarly improved potential for chondrogenesis in mesenchymal stem cells. Mesenchymal stem cells are known progenitors of the differentiated primary articular chondrocytes found in fully developed articular cartilage tissue.

The presented research was divided into three studies that demonstrated the potential of this technique to improve growth. The first study investigated the optimal method of synchronizing the differentiated cells contained in harvested tissue explants. The second study demonstrated the viability of different methods of encapsulation and recovery for flow cytometry analysis. The third and final study examined the effects of in vitro cell cycle synchronization on the growth characteristics of primary articular chondrocytes.

\subsubsection{Optimizing Synchronization in Primary Articular Chondrocytes}

Successful cell cycle synchronizing strategies were required to complete this research. Through blocking of populations with cell synchronizing agents commonly demonstrated in cell culture while varying exposure times, concentrations, and methods of facilitating improved diffusion [216, 217], it was determined that a modified double thymidine technique with a full 24 
hours for the first thymidine $(10 \mathrm{mM})$ treatment, a 9 hour release $(8$ hours in serum free media followed by 1 hour in a solution of $0.5 \% \mathrm{w} / \mathrm{v}$ protease in serum free media), and 12 hours for the second thymidine $(10 \mathrm{mM})$ treatment yielded a synchronized $(61.0 \%)$ populations of primary articular chondrocytes in the S phase of the cell cycle. This method was further optimized through enhancement of the diffusion of thymidine to the cells embedded within harvested tissue by mincing explants into slices (surface area $<5 \mathrm{~mm} \times 5 \mathrm{~mm}$ ), which was found to improve the purity of the recovered synchronous populations in S phase (92.7\%) without significantly reducing the viability of the recovered cells. Improving the facilitation of diffusion was considered as a method of improving synchronization due to the small pore size in cartilaginous ECM (approximately $6 \mathrm{~nm}$ ) [50], which affected the time required for transport of the larger molecular weight synchronizing agents throughout the tissue. Low viability of the nocodazole synchronization is attributed to its inhibition of microtubule activity, which plays an active role in the synthesis and assembly of proteoglycan content in the chondrocyte [218]. The prolonged inhibition of these structural proteins has been demonstrated to elicit cell death in other phenotypes [219].

\subsubsection{Encapsulation for Three-Dimensional Culture and Maintaining Phenotype}

A fundamental aspect of this research was the ability to analyze the cell cycle phase of populations of primary articular chondrocytes in culture. High density encapsulation was selected as a culture model because this technique enables culture of chondrocytes without the drawback of dedifferentiation associated with monolayer culture [220]. Low melting point agarose was used initially as the encapsulating hydrogel material used to create threedimensional (3D) constructs in which populations of chondrocytes would be cultured. However, recovery of viable cells from this encapsulation proved difficult, as even in the presence of an 
agarose digesting enzyme, the constructs required significant heat $\left(>60^{\circ} \mathrm{C}\right)$ to dissolve within 20 minutes in PBS under agitation. This significantly affected viability of the recovered populations $(<10 \%)$, thus this method was discounted for cell cycle analysis.

The next encapsulating material used for 3D culture of chondrocytes was alginate, an anionic polymer known for its gelation in the presence of divalent cations such as $\mathrm{Ca}^{2+}$ or $\mathrm{Mg}^{2+}$. Based on literature [221, 222], standard practices for encapsulation of chondrocytes in alginate utilize a $1.25 \% \mathrm{w} / \mathrm{v}$ solution of alginate mixed in even amounts with a high density cell suspension and added drop-wise into a $110 \mathrm{mM}$ calcium chloride solution. $30 \mu \mathrm{L}$ drops of the alginate-cell suspension mixture were added to the polymerizing calcium chloride solution and allowed to gel for a period of 10 minutes before being placed in culture. When harvesting these cells from culture at different time points, constructs were grouped ( $\mathrm{n}=6$ per group) and placed in $5 \mathrm{~mL}$ of a $55 \mathrm{mM}$ EDTA to chelate calcium and dissolve the alginate encapsulation, leaving the cells in solution and capable of being fixed for flow cytometry analysis. Notably, the staining of type I collagen did not detect a strong fluorescent signal for control or synchronized groups, indicating that the high concentration of calcium ions needed to polymerize the alginate hydrogel did not contribute to a mineralization of the tissue, which would lead to a more osseous morphology.

Maintenance of differentiated chondrocyte phenotype was assessed through histological and immunohistochemical staining. Presence of glycosaminoglycans in the territorial and interterritorial matrix of tissue sections was evident from safranin oxide staining, as seen in Figure 49. Intense collagen staining in the territorial and inter-territorial matrix were observed in tissue sections stained with the sirius red dye, as shown in Figure 4-16. Through immunohistochemical staining, it was observed that expression of type II collagen by both synchronized and 
unsynchronized chondrocytes encapsulated in alginate beads was widespread throughout tissue sections, as observed in Figure 4-17. Collagen II is the most abundant form of collagen found in articular cartilage tissue [37], and high levels of collagen II expression confirmed that the cells remained chondrogenic in this culture system. Furthermore, in both synchronized and unsynchronized groups, scarce expression of type I collagen was observed in the tissue, as seen in Figure 4-18. Type I collagen is associated with osseous tissues, as it is predominantly found in calcified tissues such as bone and the calcified layer cartilage that is situated above subchondral bone [38]. Though alginate encapsulation required the polymerization of beads in $102 \mathrm{mM}$ calcium chloride, the cells did not produce a significant amount of collagen I, indicating that they maintained their chondrogenic status and did not move towards a more osteogenic phenotype. The formation of doublets surrounded with cartilaginous matrix and the visible staining of GAG and collagen in the territorial and inter-territorial matrix at four weeks in culture support the notion that the chondrocytes embedded in alginate hydrogel beads had maintained their phenotype.

\subsubsection{Effects of Synchronization on Growth of Articular Cartilage Tissue}

The critical purpose of optimizing synchronization and encapsulation techniques for primary articular chondrocytes was to determine the effects of synchronization on the cartilaginous matrix-producing potential of these differentiated cells. Under the stimulus of cell cycle synchronization through an optimized double thymidine block, constructs populated with primary articular chondrocytes had significantly more DNA content (21\%) compared to controls, indicating an increase in cell count in the synchronized constructs compared to controls. This finding is logical given that the synchronized cells were shown to cycle as a synchronous (and 
asynchronous) population for longer than the control group before the majority of the cells returned to $\mathrm{G}_{0}$ stasis [223]. Thus, the population doublings that would occur during each synchronous cell cycle progression would give rise to more chondrocytes in the synchronized constructs compared to controls. It is also notable that the DNA content significantly decreased for both synchronized groups and control groups at four weeks in culture when compared to their respective two-week time points ( $25 \%$ and $30 \%$ decreases respectively).

Cells that underwent synchronization demonstrated a significant improvement in the amount of synthesized proteoglycans detected. Though quantitative differences were negligible at the two-week time point, a $16 \%$ increase in average sulfated glycosaminoglycan content was found in synchronized constructs compared to controls at four weeks in culture. However, no significant difference in the ratio of GAG mass to DNA mass was found for synchronized constructs compared to controls at both two weeks in culture and four weeks in culture, suggesting the increase in accumulated proteoglycan content can be attributed to a larger number of cells synthesizing matrix. Unlike the DNA mass in the constructs, the GAG mass was found to increase between 2-week and 4-week time points for the same groups ( $43 \%$ for synchronized constructs and $29 \%$ for controls). Qualitatively, the differences in staining intensity of the synchronized constructs compared to the controls were evident. At the four-week time point, the intensity of the safranin oxide staining was visibly higher and pockets of interstitial proteoglycans were more apparent. In addition, when comparing synchronized and control groups at four weeks to their two-week time-points, there was a visible increase in spacing between nuclei, which is consistent with the finding that the DNA content at 4 weeks had decreased compared to the DNA content of two-week samples. 
Collagen content significantly increased in constructs seeded with synchronized cells when compared with controls, exhibiting a $61 \%$ increase at the four-week time point. The ratio of the collagen mass to DNA mass was consistent with the ratio of GAG mass to DNA mass. At the four-week time point, a 33\% increase in the Collagen/DNA ratio was found, suggesting the increased synthesis of collagens is not simply a result of an increased number of cells in the synchronized constructs. The collagen/DNA ratios indicate that either the cells in the synchronized constructs were producing more collagen on a per cell basis, or the increase in accumulated collagen occurred simultaneously with a decrease in DNA content and the increased amount of synthesized collagen in the four week synchronized constructs could not be solely attributed to an increased number of cells in the synchronized constructs producing the same proportion of collagen. Collagen content significantly increased over time when comparing the synchronized (3.9-fold increase) and control (3.3-fold increase) groups at four weeks to their respective two-week time points. This data is consistent with the sections imaged with sirius red, which demonstrated a visible increase in the amount of collagen found in the territorial matrix of the chondrocytes. It is also consistent with the immunohistochemical staining for collagen II, in which the visible staining in the territorial and inter-territorial matrix was apparent at both twoweek and four-week time points, with demonstrably more fluorescent signal in the four week samples when compared with their respective two-week time points. 


\subsection{Synchronization Mechanisms and Improved Growth}

\subsubsection{Proliferative Effects of a Cell Cycle Synchronized Population}

Synchronization had an increasing effect on proliferation of constructs with a significant $21 \%$ increase in DNA content at four weeks when compared to controls. This observation is consistent with findings in literature which state that cell cycle synchronization can shorten the duration of specific cell cycle phases [224-227]. This would account for the increased DNA content that was observed in synchronized constructs compared to controls, but does not explain the improved ratio of collagen to DNA. The decrease in DNA content at four weeks compared to two-week time points was significant for both synchronized (25\%) and control (30\%) groups. This corresponds to a consistent decrease in the number of cells found in constructs at four weeks compared to their two-week time points, which on surface level is at odds with the increased levels of synthesized extracellular matrix at four weeks.

The decreased cell numbers in four-week time point constructs was postulated to be related to the population growth kinetics of the primary articular chondrocytes in each construct. Cell populations, much like bacteria in culture, are observed to follow a standard growth curve, with an initial lag phase during which metabolic activity increases and division halts [228, 229]. This is followed by a period termed the growth phase, in which the population size increases in an exponential manner $[228,229]$. Following this, a steady-state is reached during which the nutrients that are required by the cells and the toxic byproducts of their metabolic and catabolic pathways balance out in equilibrium of replication and cell death [228]. Static culture conditions are optimized to replenish nutrient supply and remove toxic byproducts to continually expand the number of cells being cultured and prolong the growth phase before reaching equilibrium [223]. 
It is established in literature that the majority of differentiated cell function occurs during the steady-state period [229-232], followed by a decrease in population numbers due to a lack of available nutrients and space within the tissue to sustain the expanding population $[229,233-$ 235]. The remaining constraint on the population size is the volume of the construct.

It is proposed that at some critical point during the four-week culture of these chondrocytes in alginate beads, this steady-state was reached during which the number of dividing cells and apoptotic cells were balanced. Hence, the expansion would have continued to occur past the two-week time point, where the DNA content was found to be higher than the four-week time point. Between two weeks and four weeks in culture, the expanded chondrocytes would reach a point where either the $1 \mathrm{~mL}$ of media that each construct was supplemented with at each feed cycle was not enough to sustain continued growth of the population within the construct, or alternatively the number of cells in the construct had increased to a critical point at which not all embedded cells had equal access to the nutrient supply, resulting in necrosis. The four-week DNA content data of both the synchronized and control groups support this notion.

Synchronization of in vitro cultures has been shown to alter duration of specific phases of the cell cycle and consequently the overall length of time required for division [227]. It is assumed that the optimized synchronization technique used on primary articular chondrocytes led to a similar shortening of the initial lag phase when the constructs were put into culture, accelerating the time in which these populations reached the steady-state where anabolic pathways are theorized to be most active [233-235]. Evidence of this can be seen in the flow cytometry analysis of synchronized and unsynchronized groups at 12 hour increments up to 48 hours in culture. This data clearly exhibits the accelerated onset of population expansion in the synchronized group compared to the control, with the majority of the population appearing to 
cycle synchronously up to 24 hours before a small percentage of cells began to trail.

Comparatively, only a small percentage of the control population appeared to progress through the cell cycle within the first 48 hours in culture, suggesting they took longer to adapt to the culture model and begin expansion. This would account for some of the significant increases in cell number and synthesized matrix detected in the synchronized groups compared to controls [268].

\subsubsection{Growth Factor Signaling in a Synchronized Population}

Further examining the mechanisms that promote the synthesis of cartilaginous extracellular matrix in primary articular chondrocytes, it is evident in literature that specific growth factors found in cartilaginous ECM can have profound effects on both the cell cycle of nearby cells and their synthesis of matrix [50]. While some of these growth factors are secreted in other areas of the body to act exogenously, many can be secreted by the primary articular chondrocytes during matrix synthesis to act endogenously during matrix upkeep $[50,55,56$, 236]. The role of the extracellular matrix as a regulator of the development of cartilage tissue through growth factor and morphogen signaling has been established in literature $[55,56,236]$. The overlap of function between cell cycle regulation and matrix synthesis in primary articular chondrocytes make these growth factors a plausible origin of improved growth in synchronized primary articular chondrocytes. In a synchronized population, the local concentrations of the endogenously released growth factors would be sharply increased at specific points in the cell cycle, thus leading to a marked increase in any effects of these growth factors that occur in a dose-dependent manner. Differential expression of anabolic growth factors as chondrocytes progress through the cell cycle $[57,58,237,238]$ could be responsible for improved growth 
characteristics observed, with local concentrations of these differentially expressed growth factors increasing in a synchronized population.

Connective Tissue Growth Factor (CTGF or CCN2) is a mitogenic protein of the CCN family of extracellular matrix proteins that are associated with intercellular signaling [239]. The protein is secreted by vascular endothelial cells, and known to elicit proliferation and differentiation of chondrocytes [239, 240]. It is known to push cells from $\mathrm{G}_{0}$ stasis into the $\mathrm{G}_{1}$ phase of the cell cycle [241]. It is also involved in cellular adhesion, skeletal development, and wound repair processes $[239,240,242]$. It is regulated by the SOX9 transcription factor that regulates most growth factors involved in stimulating tissue production in chondrocytes [243]. In terms of active sites on the CTGF protein, the N-terminal insulin-like growth factor binding protein (IGFBP) and von Willebrand factor type C (VWC) domains both directly interact with aggrecan molecules and this binding is suggested to be responsible for CTGF-mediated enhancement of aggrecan production and secretion in chondrocytes [242]. This culture model lacked vascularization and was only seeded with primary articular chondrocytes which aren't known to produce the protein, but CTGF stimulation of encapsulated primary articular chondrocytes could occur exogenously via exposure to serum containing media at each feed cycle. This paracrine signaling of cells that are already progressing through the cell cycle would account for some of the proliferative and anabolic improvements detected in the synchronized group compared to controls which were generally quiescent in the first 48 hours in culture.

Fibroblast Growth Factors (FGF) are a family of growth factors that are known to regulate the proliferation, differentiation, and matrix synthesis of chondrocytes. The cell signaling proteins are synthesized in various different tissues in the body and are consequently responsible for a wide range of different cellular activity. FGF-2, an isoform of FGF synthesized 
in the perichondrium, is involved in articular cartilage morphogenesis and tissue repair [244]. It promotes chondrogenesis through signaling of the FGFR3 receptor [245]. It has also been demonstrated to stimulate a thickening of the articular cartilage layer in an injury-induced model of osteoarthritis in an in vivo murine model [245]. A knockout study of FGF18 in a murine model demonstrated its ability to upregulate proliferation in chondrocytes and other mesenchyme-derived cells [59]. A previous study that examined the activity of FGF determined that its downstream receptor FGFR tyrosine kinase binds to an unphosphorylated FGFR substrate (FSR2) which, when phosphorylated, causes release of Cks1 from FSR2 [60]. Cks1 has been shown to promote the degradation of $\mathrm{p} 27^{\mathrm{kip} 1}$, a known inhibitor of cyclin $\mathrm{E}$ and consequently progression into the cell cycle [60]. Additionally, a previous study examining immunocytochemical nuclear and cytoplasmic staining of FGF determined that it is expressed in abundance approximately 2 hours before entry into S phase (97\% of cells are immuno-positive for FGF) [246]. This was followed by a rapid decline in nuclear and cytoplasmic staining following entry into S phase [246]. This supports the idea that transient, cell-cycle dependent expression of this growth factor plays a role in the upregulation of both cell cycle entry of the chondrocytes and promotion of matrix synthesis.

Insulin-like Growth Factor-I (IGF-I, also known as somatomedin C) is the main anabolic growth factor that acts on primary articular chondrocytes, known for enhancing cell cycle progression from the $\mathrm{G}_{1}$ checkpoint to the $\mathrm{S}$ phase [247]. It is a protein similar in molecular structure to insulin, and exhibits anabolic effects during tissue growth [248, 249]. While the molecule is primarily secreted by the liver to act as an endocrine hormone, it has also been shown to be synthesized by target tissues to act as a paracrine/autocrine hormone [249-251]. Its role in mitogenic signaling involves phosphorylation and degradation of the p27 inhibitor (a 
phosphoprotein which universally inactivates cyclin dependent kinase proteins) and up regulation of cyclin E [252-254]. Cyclin E binds to cyclin-dependent kinase 2 during the $\mathrm{G}_{1}$ phase to promote progress into the S phase [254]. It has been observed that IGF-I expression increases during the G1 phase in immortal cell lines [255]. Stimulation of this growth factor on encapsulated chondrocytes could have occurred both endogenously through secretion from encapsulated primary articular chondrocytes and exogenously through intake of serum in media at each feed cycle. Resultant degradation of the p27 inhibitor of cell cycle progression likely enhanced the continued progression of synchronized cells through the cell cycle, leading to increased cell counts and improved anabolic activity. Conversely, the effects of this growth factor on cells in the control group would be decreased since they contained a significant population of cells that remained quiescent in the first 48 hours of in vitro culture. IGF-I is also critical in balancing the synthesis and breakdown of proteoglycans during cartilage homeostasis. It has been demonstrated that IGF-I stimulation improves proteoglycan synthesis and reduces proteoglycan catabolism in a dose-dependent manner [256]. In addition to the continued progression of the synchronous population through the cell cycle, the improved proteoglycan synthesis may also be attributed to IGF-I stimulation in the culture system. The cell cycle progression of the synchronized group would lead to expression of this growth factor in a sharply increased concentration during specific phases of upregulation that occur during the G1 phase, simultaneously promoting further proteoglycan synthesis in these cells.

Platelet-derived Growth Factor (PDGF) is another anabolic growth factor that is involved in cell cycle progression. It is a dimeric glycoprotein that has been demonstrated to drive a variety of cellular fate processes including proliferation, migration, differentiation, and function in a variety of mesenchyme-derived cells during development and in the adult animal 
[257]. The glycoprotein, which is synthesized by a variety of different cell types [257], consists of two functional subunits (either A or B, for the combinations AA, BB, and AB) [258]. The role of PDGF-AA and PDGF-BB in promoting cell cycle entry has been widely explored, with their regulation of p27 activity allowing cells to proliferate [258]. PDGF-AA is considered to be a competent factor, meaning it enables progression into the cell cycle in the presence of certain progression factors in serum. PDGF-BB can be a competent and progression factor, meaning it is capable of stimulating cell cycle entry itself [258]. PDGF signaling in this culture system may also be exogenous since it is the most potent mitogen found in serum [259]. Specifically, proliferation is accelerated by PDGF via reduction of the $\mathrm{G}_{1}$ checkpoint phase. This reduction is caused by regulation of the p21 and p53 cyclin and cyclin dependent kinase inhibitors [258]. Furthermore, in mesenchyme-derived connective tissue cell types such as fibroblasts, exogenous administration of PDGF has been shown to stimulate proliferation and gene expression, accelerating extracellular matrix and collagen formation and thus expediting the tissue formation and wound healing responses [260]. In a population that is already synchronously progressing through the cell cycle, this PDGF-driven acceleration of collagen formation is postulated to be further decreasing the amount of time required for scale up. PDGF has also been demonstrated to improve proteoglycan synthesis in resting zone chondrocytes, which points to it being a potential cause of the improved matrix synthesis in synchronized samples.

Transforming Growth Factor Beta (TGF- $\beta$ ) refers to a family of cytokine proteins secreted by all white blood cell lineages. Signaling of these proteins is strongly linked with synthesis of articular cartilage tissue [261]. In most cell types, isoforms of this protein are responsible for arresting cells at the G1/S boundary of the cell cycle via synthesis of $\mathrm{p} 15$ and $\mathrm{p} 21$ cyclin and cyclin dependent kinase inhibitors $[262,263]$. However, TGF- $\beta$ proteins are known 
to have stimulatory effects on proliferation of chondrocytes in vitro [261, 264, 265]. While isolated TGF- $\beta$ treatment in low levels of serum has been shown to arrest cells at the G1/S boundary in similar fashion to other cell types, in presence of $10 \%$ serum or higher, TGF- $\beta$ increased rates of proliferation, suggesting it is a competent factor that works in tandem with another factor in serum [265]. A follow up study elucidated one method through which this bidirectional regulation of cell cycle occurs through TGF- $\beta$ [266]. In this study, it was determined through synchronization that cells in specific phases of the cell cycle expressed different high affinity binding sites for TGF- $\beta 1$, suggesting transient expression of different receptors for the growth factor as cells progressed through the cell cycle [266]. Studies of the effects of TGF- $\beta$ on subsequent cyclin and cyclin-dependent kinase expression would clarify the transient effects of this growth factor on the cell cycle. In vivo studies of cyclin D1 expression have shown that TGF- $\beta$ stimulation in tandem with endogenously expressed parathyroid hormone related protein (PTHrP) activate the transcription factor ATF-2 and related CREB transcription factors to promote cyclin D1 transcription in chondrocytes $[53,56]$. Expression of TGF- $\beta 1$ and 3 were found to correlate with a 9-fold increase in levels of PTHrP mRNA expression [267], suggesting these two isoforms of TGF- $\beta$ are responsible for a large amount of the continued proliferation of cycling chondrocytes in the growth phase. Through presence in serum administered in media at each feed cycle in addition to endogenous expression of these synthesized growth factors by chondrocytes in culture, it is postulated that TGF-B played a key role in the continued proliferation and matrix synthesis of the synchronized group compared. It is proposed that the activity of these growth factors that exert anabolic and mitogenic effects on cells originating from the mesenchyme likely enhanced the tissue formation of a population of synchronously dividing primary chondrocytes. IGF-I, PDGF, and TGFB-1 and 3 in particular 
have been shown to promote proliferation of chondrocytes as well as synthesis of extracellular matrix molecules through their extensive signaling pathways, and are thus postulated to have had the most significant effects on overall matrix synthesis due to the sharp concentration increases that would occur as the cells cycled synchronously. Differential expression of the growth factors through the cell cycle has been demonstrated, and the subsequent local concentration increases of endogenously expressed growth factors represent the most probable cause of the accelerated synthesis in synchronized groups. This phenomenon of rapid tissue formation in the differentiated chondrocyte phenotype should be harnessed to expedite the amount of time required to generate an appreciable tissue explant for implantation at the defect site. 


\section{Chapter 6 Conclusions and Recommendations}

\subsection{Conclusions}

Cell cycle synchronization was investigated for its ability to improve synthesis in primary articular chondrocytes. The objectives of this study were two-fold: (i) identify a method to successfully synchronize cell cycle in primary articular chondrocytes without eliciting de-differentiation, and (ii) explore the effects of cell cycle synchronization on the chondrogenic potential of primary articular chondrocytes. Previous studies that examined synchronization in cartilage tissue engineering had demonstrated its ability to improve cartilaginous matrix deposition when performed in monolayer culture of mesenchymal stem cells. In this study, similarly improved growth characteristics have been shown to hold true for the differentiated primary articular chondrocytes when performed in three-dimensional alginate bead culture. In modern tissue engineering approaches, the objective of rapid synthesis of cartilaginous extracellular matrix is fundamental in creating tissue on an appreciable scale for implantation. While it is easier to source a large population of mesenchymal stem cells (the progenitor cells that give rise to the specialized primary articular chondrocytes found in articular cartilage tissue in vivo), the time taken to differentiate these cells before they begin forming the cartilaginous extracellular matrix required for implantation represents a significant drawback.

The results of this experimentation can be condensed into three main conclusions. The initial finding was that alginate bead encapsulation was the preferred scaffold system in which to culture these cells when considering downstream analysis. The second conclusion drawn from this research was that the optimal method of synchronizing the cell cycle phase of primary articular chondrocytes embedded in harvested tissue explants was a modified double thymidine block treatment. The fundamental discovery of this research was that synchronizing the cell cycle phase of the population of seeded cells increased the rate of tissue deposition. 


\subsubsection{Encapsulation of Primary Articular Chondrocytes}

Alginate bead encapsulation $(1.25 \% \mathrm{w} / \mathrm{v})$ was chosen as the optimal method of encapsulation for this study. While encapsulating cells in cylindrical constructs allowed for mechanical testing of the synthesized cartilage, there were drawbacks to this approach. In the case of alginate cylindrical encapsulation, the constructs did not hold their form and would often break in culture, preventing testing of the biochemical properties of synthesized cartilage. Conversely, the agarose hydrogel constructs maintained their shape well but did not allow for a high yield on the recovery of encapsulated populations. Even with the utilization of enzymatic digestion of agarose, the temperatures required to dissolve these constructs within a reasonable time frame damaged the DNA of the cells, thus affecting the flow cytometric analysis of cell cycle phase that was required to determine how long populations would remain synchronized in that culture model.

\subsubsection{Optimizing Synchronization in Primary Articular Chondrocytes}

A modified double thymidine block with a dose of $10 \mathrm{mM}$ thymidine and a 24 hour first block, 9-hour release ( 8 hours in serum free media followed by an hour of protease digestion in serum free media), and 12 hour second block (coupled with the collagenase digestion) was found to be the optimal technique for isolating synchronized primary articular chondrocytes. Bovine cells isolated from articular cartilage tissue of freshly slaughtered calf were found to remain viable $(>90 \%)$ and exhibit high purity $(>90 \%)$ when subjected to the modified double thymidine block. Comparatively, the standard double thymidine block was found to have a lower purity $(<70 \%)$, and other cell cycle synchronizing agents such as nocodazole, aphidicolin, and RO-3306 elicited cell death or showed less significant effects on cell cycle phase of the population. Furthermore, the population that was subjected to the modified double thymidine technique was observed at 12 -hour time points post-synchronization up to 48 hours, and was found to lose synchronization approximately 24 hours after encapsulation. 


\subsubsection{Effects of Synchronization on Matrix Synthesis in Long- Term Culture}

Constructs seeded with synchronized primary articular chondrocytes demonstrated a significant increase in both sulfated glycosaminoglycan content and collagen content at four weeks in culture. The ratio of collagen to DNA content at four weeks in culture was significantly increased in synchronized constructs compared to controls, suggesting that the synchronization process increased the amount of collagen synthesized per cell. Further work is required to elucidate the mechanisms by which cell cycle synchronization enables more rapid synthesis of cartilaginous matrix in primary articular chondrocytes. 


\subsection{Recommendations}

\subsubsection{Culture System for Articular Chondrocytes}

High density alginate bead encapsulation provides a superior culture system for this application, as it enables recovery of cells from scaffolds for cell cycle analysis of primary articular chondrocytes. In the future, experiments should continue to utilize the alginate bead method method to ensure high viability on recovery of encapsulated cells. For experiments that require more robust cylindrical constructs to perform testing of mechanical properties, higher concentrations of alginic acid (5\% or $2.5 \%)$ and calcium chloride (200 $\mathrm{mM}$ or higher) solutions are recommended to increase the strength of the polymerized construct.

\subsubsection{Utilizing Synchronization to Promote Growth in Human Chondrocytes}

In order to assess whether the results of this experiment can have clinical impact, a translational study using human chondrocytes is required. If similar results are observed, the clinical relevance of the findings can be analyzed further to determine if this method has future clinical potential. In addition, by working with human cells, the cyclin proteins that are differentially expressed across phases of the cell cycle can be analyzed using antibody-tagged fluorochromes that can be used to sort populations. The antibodies for most cyclin proteins in humans and rabbit isoforms are readily available, but unfortunately do not currently exist for bovine cells. By utilizing these antibodies, the purity of the synchronized populations in a specific phase can be validated with higher resolution sensitivity. 


\subsubsection{Mechanisms that Promote Growth in Synchronized Chondrocytes}

While the beneficial effects of synchronization on growth characteristics have been demonstrated in this model, the underlying mechanisms responsible for increased matrix synthesis remain unclear. Short-term matrix synthesis effects in cartilage tissue are commonly investigated via radioisotope incorporation of $\left[{ }^{35} \mathrm{~S}\right]$-sulfate and $\left[{ }^{3} \mathrm{H}\right]$-proline. This would allow for analysis at several shorter time points to hone in on a shorter range of time in which the difference in growth becomes apparent between synchronized constructs and controls. If the effects are shown to be occurring in a short timeframe, then consistent re-synchronization in culture should be examined as a method of sustaining the improved rate of matrix deposition. Additionally, the shortening of the cell cycle duration that occurs when cells are synchronized is likely linked to a shift to the logarithmic growth phase in terms of proliferation kinetics. Thus, the analysis of proliferation and matrix synthesis at shorter, more frequent intervals would allow for a definitive measure of these kinetics in relation to tissue growth. Finally, examining concentrations of growth factors in the media as well as those localized within the tissue could clarify their role in the improved growth exhibited. Since many growth factors involved with articular cartilage tissue development are known to play a key role in progression through the cell cycle, examining the local and media concentrations could provide insight into which specific growth factors correlate with the improved matrix synthesis found in synchronized populations. 


\section{References}

[1] Sophia Fox AJ, Bedi A, Rodeo SA. The basic science of articular cartilage: structure, composition, and function. Sports Health. 2009 Nov; 1(6): 461-468. Doi: 10.1177/1941738109350438.

[2] Tiku ML, Sabaawy HE. Cartilage regeneration for treatment of osteoarthritis: a paradigm for nonsurgical intervention. Ther. Adv. Musculoskelet. Dis. 2015 Jun; 7(3): 76-87. Doi: 10.1177/1759720X15576866.

[3] Vos T, Allen C, Arora M et. Al. Global, regional, and national incidence, prevalence, and years lived with disability for 310 diseases and injuries, 1990-2015. Lancet. 2016 Oct; 388(10053): 1545-1602. Doi:

10.1016/S0140-6736(16)31678-6

[4] Cram P, Lu X, Kates SL, Singh JA, Li Y, Wolf BR. Total knee arthroplasty volume, utilization, and outcomes among Medicare beneficiaries, 1991-2010. JAMA. 2012 Sep; 308(12): 1227-1236. Doi: 10.1001/2012.jama.11153

[5] Shan L, Shan B, Suzuki A, Nouh F, Saxena A. Intermediate and long-term quality of life after total knee replacement. J. Bone Joint Surg. 201 Jan; 97(2): 156-168. Doi: 10.2106/JBJS.M.00372.

[6] Ward BD, Lubowitz JH. Basic knee arthroscopy part 4: chondroplasty, meniscectomy, and cruciate ligament evaluation. Arthrosc. Tech. 2013 Nov; 2(4): e507-508. Doi: 10.1016/j.eats.2013.07.011.

[7] Iannitti T, Lodi D, Palmieri B. Intra-articular injections for the treatment of osteoarthritis. Drugs R D. 2011 Mar; 11(1): 13-27. Doi: 10.2165/11539760-000000000-00000

[8] Weber AE, Locker PH, Mayer EN, Cvetanovich GL, Tilton AK, Erickson BJ, Yanke AB, Cole BJ. Clinical outcomes after microfracture of the knee. Orthop. J. Sports Med. 2018 Feb; 6(2): 2325967117753572. Doi: $10.1177 / 23252967117753572$.

[9] Patil S, Tapasvi SR. Osteochondral autografts. Curr Rev Musculoskelet Med. 2015 Dec; 8(4): 423-428. Doi: 10.1007/s12178-015-9299-2.

[10] Torrie AM, Kesler WW, Elkin J, Gallo RA. Osteochondral allografts. Curr Rev Musculoskelet Med. 2015 Dec; 8(4): 413-422. Doi: 10.1007/s12178-015-9298-3.

[11] Vasiliadis HS, Wasiak J. Autologous chondrocyte implantation for full thickness articular cartilage defects of the knee. Cochrane Database Syst. Rev. 2010 Oct; 6(10):CD003323. Doi: 10.1002/14651858.CD003323.pub3.

[12] Britterberg M, Lindahl A, Nilsson A, Ohlsson C, Isaksson O, Peterson L. Treatment of deep cartilage defects in the knee with autologous chondrocyte transplantation. N Engl J Med. 1994 Oct; 331(14): 889-895. Doi:

10.1056/NEJM199410063311401

[13] Jacobi M, Villa V, Magnussen RA, Neyret P. MACI- a new era. Sports Med Arthrose Rehabil Ther Technol. 2011 May; 3(1): 10-17. Doi: 10.1186/1758-2555-3-10.

[14] Kreuz PC, Kalkreuth RH, Niemeyer P, Uhl M, Erggelet C. Long-term clinical and MRI results of matrix assisted autologous chondrocyte implantation for articular cartilage defects of the knee. Cartilage. 2018 Feb; 1947603518756463. Doi: 10.1177/1947603518756463 
[15] Howard D, Buttery LD, Shakesheff KM, Roberts SJ. Tissue engineering: strategies, stem cells, and scaffolds. J. Anat. 2008 Jul; 213(1): 66-72. Doi: 10.1111/j.1469-7580.2008.00878.x

[16] Vunjak-Novakovic G, Martin I, Obradovic S, Treppo A, Grodzinsky AJ, Langer R, Freed LE. Bioreactor cultivation conditions modulate the composition and mechanical properties of tissue engineered cartilage. Journal of Orthopaedic Research. 1999 Jan; 17(1): 130-138. Doi: 10.1002/jor.1100170119

[17] Martin S. Deconstructing the Cell Cycle. Mol. Cell Biol. 2011 Sep; 12(11): 689-695. Doi: 10.1038/nrm3205.

[18] Tan AR, Martin-Pena A, Bulinski JC, Hung CT. "Cell Cycle Synchronization During 2d Growth Enhances 3d Chondrogenesis," presented at ORS, Las Vegas, NV, 2015.

[19] Juanes MA. Methods of synchronization of yeast cells for the analysis of cell cycle progression. Meth. Mol. Biol. 2016 Nov; 150(5): 19-34.

[20] Lee JS, Lee JY, Chae BC, Jang JH, Lee EA, Son YS. Fully dedifferentiated chondrocytes expanded in specific mesenchymal stem cell growth medium with FGF2 obtains mesenchymal stem cell phenotype in vitro but retains chondrocyte phenotype in vivo. Cell Transplant. 2017 Oct; 26(10): 1673-1687. Doi: 10.1177/0963689717724794.

[21] Buckwalter JA, Mankin HJ. Articular cartilage, part 1: tissue design and chondrocyte-matrix interaction. J Bone Joint Surg Am. 1997 Dec; 79(6): 600-611.

[22] Akizuki S, Mow VC, Müller F, Pita JC, Howell DS, Manicourt DH. Tensile properties of human knee joint cartilage: I. Influence of ionic cartilage conditions, weight bearing and fibrillation on the tensile modulus. J Orthop Res. 1986 Apr; 4(4): 379-392.

[23] Buckwalter JA, Rosenberg LA, Hunziker EB. Articular Cartilage and Knee Joint Function: Basic Science and Arthroscopy. New York, NY: Raven Press; 1990.

[24] Aigner T, Hemmel M, Neureiter D, et al. Apoptotic cell death is not a widespread phenomenon in normal aging and osteoarthritis human articular knee cartilage: a study of proliferation, programmed cell death (apoptosis), and viability of chondrocytes in normal and osteoarthritic human knee cartilage. Arthritis \& Rheumatism. 2001 Jun; 44(6): 1304-1312.

[25] Muir H. The chondrocyte, the architect of cartilage: biomechanics, structure, function and molecular biology of cartilage matrix molecules. Bioessays. 1995 Dec; 17(12): 1039-1048

[26] Buckwalter JA, Mow VC, Ratcliffe A. Restoration of injured or degenerated articular cartilage. J Am Acad Orthop Surg. 1994 Jan; 2(1):192-201

[27] Eggli PS, Herrmann W, Hunziker EB, Schenk RK. Matrix compartments in the growth place of the proximal tibia of rats. Anat Rec. 1985 Apr; 211(4): 246-257

[28] Guilak F, Mow VC. The mechanical environment of the chondrocyte: a biphasic finite element model of cellmatrix interactions in articular cartilage. J Biomech. 2000 Mar; 33(3): 1663-1673.

[29] Mow VC, Guo XE. Mechano-electrochemical properties of articular cartilage: their inhomogeneities and anisotropies. Annu Rev Biomed Eng. 2002 Jul; 4(7): 175-209. 
[30] Armstrong CG, Mow VC. Variations in the intrinsic mechanical properties of human articular cartilage with age, degeneration, and water content. J Bone Joint Surg. 1982 Nov; 64(11): 88-94.

[31] Mankin HJ, Thrasher AZ. Water content and binding in normal and osteoarthritic human cartilage. J Bone Joint Surg. 1975 Jun; 57(6): 76-80.

[32] Hardingham TE, Fosang AJ. Proteoglycans: many forms and many functions. FASEB J. 1992 Feb; 6(2): 861870 .

[33] Lohmander S. Proteoglycans of joint cartilage: structure, function, turnover, and role as markers of joint disease. Baillieres Clin. Rheumatol. 1988 Jan; 2(1): 37-62.

[34] Roughley PJ. Structural changes in the proteoglycans of human articular cartilage during aging. J. Rheumatol. 1987 Oct; 14(10): 14-15.

[35] Aspberg A. The different roles of aggrecan interaction domains. J. Histochem. Cytochem. 2012 Dec; 60(12): 987-996. Doi: 10.1369/0022155412464376.

[36] Vigetti D, Karousou E, Viola M, Deleonibus S, De Luca G, Passi A. Hyaluronan: biosynthesis and signaling. Biochim. Biophys. Acta. 2014 Aug; 1840(8): 2452-2459. Doi: 10.1016/j.bbagen.2014.02.001.

[37] Eyre DR, Wu JJ, Apone S. A growing family of collagens in articular cartilage: identification of 5 genetically distinct types. J Rheumatol. 1987 Mar; 14(3) 25-27.

[38] Mienaltowski MJ, Birk DE. Structure, physiology, and biochemistry of collagens. Adv. Exp. Med. Biol. 2014 Aug; 802(8): 5-29. Doi: 10.1007/978-94-007-7893-1_2.

[39] Goldring MB. Chondrogenesis, chondrocyte differentiation, and articular cartilage metabolism in health and osteoarthritis. Ther. Adv. Musculoskelet. Dis. 2012 Aug; 4(4): 269-285. Doi: 10.1177/1759720X12448454.

[40] Lefebvre V, Dvir-Ginzberg M. SOX9 and the many facets of its regulation in the chondrocyte lineage.

Connect. Tissue Res. 2017 Jan; 58(1): 2-14. Doi: 10.1080/03008207.2016.1183667.

[41] Cheah KS, Stoker NG, Griffin JR, Grosveld FG, Solomon E. Identification and characterization of the human type II collagen gene (COL2A1). PNAS. 1985 May; 82(9): 2555-2559. Doi: 10.1073/pnas.82.9.2555

[42] Hamada T, Sakai T, Hiraiwa H, Nakashima M, Ono Y, Mitsuyama H, Ishiguro N. Surface markers and gene expression to characterize the differentiation of monolayer expanded human articular chondrocytes. Nagoya J. Med. Sci. 2013 Feb; 75(2): 101-111.

[43] Dijkgraaf LC, de Bont LG, Boering G, Liem RS. Normal cartilage structure, biochemistry, and metabolism: a review of the literature. J. Oral Maxillofac. Surg. 1995 Aug; 53(8): 924-929.

[44] Akkiraju H, Nohe A. Role of chondrocytes in cartilage formation, progression of osteoarthritis, and cartilage regeneration. J Dev. Biol. 2015 Dec; 3(4): 177-192. Doi: 10.3390/jdb3040177.

[45] Maldonado M, Nam J. The role of changes in extracellular matrix of cartilage in the presence of inflammation on the pathology of osteoarthritis. Biomed. Res. Int. 2013 Aug; 24(4): 2848-2873. Doi: 10.1155/2013/284873. 
[46] Arkill KP, Winlove CP. Solute transport in the deep and calcified zones of articular cartilage. Osteoarthritis Cartilage. 2008 Jun; 16(6): 708-714. Doi: 10.1016/j.joca.2007.10.001.

[47] Malinin T, Ouellette EA. Articular cartilage nutrition is mediated by subchondral bone: a long-term autograft study in baboons. Osteoarthritis Cartilage. 2000 Aug; 8(8): 483-491. Doi: 10.1053/joca.1999.0324.

[48] Ingelmark BE. The nutritive supply and nutritional value of synovial fluid. Acta. Orthop. Scand. 1950 Jul; 20(2): 144-155. Doi: 10.3109/17453675009043413.

[49] Tandon PN, Agarwal R. A study of nutritional transport in a synovial joint. Comp. Math. App. 1989 Jul; 17(7): 1131-1141. Doi: 10.1016/0898-1221(89)90043-6.

[50] Pan J, Zhou X, Li W, Novotny JE, Doty SB, Wang L. In situ measurement of transport between subchondral bone and articular cartilage. J. Orthop. Res. 2009 Oct; 27(10): 1347-1352. Doi: 10.1002/jor.20883.

[51] Treadwell BV, Mankin HJ. The synthetic processes of articular cartilage. Clin. Orthop. Relat. Res. 1986 Dec; 213(12): 50-61.

[52] Iozzo RV, Schaefer L. Proteoglycan form and function: a comprehensive nomenclature of proteoglycans. Matrix Biol. 2015 Mar; 42(3): 11-55. Doi: 10.1016/jmatbio.2015.02.003.

[53] Wess TJ. Collagen fibril form and function. Adv. Protein Chem. 2005 May; 70(5): 341-374. Doi: 10.1016/S0065-3233(05)70010-3.

[54] Osborn KD, Trippel SB, Mankin HJ. Growth factor stimulation of adult articular cartilage. J. Orthop. Res. 1989 Jan; 7(1): 35-42. Doi: 10.1002/jor.1100070106.

[55] Taipale, J and Keski-Oja, J. Growth factors in the ECM. FASEBJ. 1997 Jan; 11(1): 51-59.

[56] Shi S, Chan AG, Mercer S, Eckert GJ, and Trippel SB. Endogenous versus Exogenous Growth Factor Regulation of Articular Chondrocytes. J. Orthop. Res. 2014 Jan; 32(1): 54-60. Doi: 10.1002/jor.22444

[57] Jones SM and Kazlauskas A. Growth factor-dependent signaling and cell cycle progression. FEBS Lett. 2001 Feb; 490(3), 110-116. Doi: 10.1016/S0014-5793(01)02113-5

[58] Jones SM and Kazlauskas A. Growth-factor-dependent mitogenesis requires two distinct phases of signalling. Nat. Cell Biol. 2001 Feb; 3(2): 165-172. Doi: 10.1038/35055073

[59] Ohbayashi N, Shibayama M, Kurotaki Y, Imanishi M, Fujimori T, Itoh N, Takada S. FGF18 is required for normal cell proliferation and differentiation during osteogenesis and chondrogenesis. Genes. Dev. 2002 Apr; 16(7): 870-879. Doi: 10.1101/gad.965702.

[60] Zhang Y, Lin Y, Bowles C, Wang F. Direct Cell Cycle Regulation by the Fibroblast Growth Factor Receptor (FGFR) Kinase through Phosphorylation-dependent Release of Cks1 from FGFR Substrate 2. J. Biol. Chem. 2004 Dec; 279(53): 55348-55354. Doi: 10.1074/jbc.M409230200.

[61] Caterson B, Flannery CR, Hughes CE, Little CB. Mechanisms involved in cartilage proteoglycan catabolism. Matrix Biol. 2000 Aug; 19(4): 333-344. 
[62] Rowan AD. Cartilage catabolism in arthritis: factors that influence homeostasis. Expert Rev. Mol. Med. 2001 Jul; 5(7): 1-20. Doi: 10.1017/S1462399402003209.

[63] Stevens AL, Wishnok JS, White FM, Grodzinsky AJ, Tannenbaum SR. Mechanical injury and cytokines cause loss of cartilage intergrity and upregulate proteins associated with catabolism, immunity, inflammation, and repair.

Mol. Cell Proteomics. 2009 Jul; 8(7): 1475-1489. Doi: 10.1074/mcp.M800181-MCP200.

[64] Slowman SD, Brandt KD. Composition and glycosaminoglycan metabolism of articular cartilage from habitually loaded and habitually unloaded sites. Arth. Rheum. 1986 Jan; 29(1): 88-94. Doi:

10.1002/art.1780290112.

[65] Manka SW, Carafoli F, Visse R, Bihan D, Raynal N, Farndale RW, Murphy G, Enghild JJ, Hohenester E, Nagase H. Structural insights into triple helical collagen cleave by matrix metalloproteinase 1. PNAS. 2012 Jul; 109(31): 12461-12466. Doi: 10.1073/pnas.1204991109/

[66] Fields GB. Interstitial collagen catabolism. J. Biol. Chem. 2013 Mar; 288(13): 8785-8793. Doi: 10.1074/jbc.R113.451211.

[67] Ali SY, Evans L, Stainthorpe E, Lack CH. Characterization of cathepsins in cartilage. Biochem. J. 1967 Nov; 105(2): 549-557.

[68] Mitchell PG, Magna HA, Reeves LM, Lopresti LL, Yocum SA, Rosner PJ, Geoghegan KF, Hambor JE. Cloning, expression, and type II collagenolytic activity of Matrix Metalloproteinase-13 from human osteoarthritic cartilage. J. Clin. Invest. 1996 Feb; 97(3): 761-768. Doi: 10.1172/JCI118475.

[69] Imai K, Ohta S, Matsumoto T, Fujimoto N, Sato H, Seiki M, Okada Y. Expression of memnrane-type 1 matrix metalloproteinase and activation of progelatinase A in human osteoarthritic cartilage. Am. J. Pathol. 1997 Jul; 151(1): 245-256.

[70] Wu JJ, Lawk MW, Chun LE, Eyre DR. Sites of Stromelysin cleavage in collagen types II, IX, X, and XI of cartilage. J. Biol. Chem. 1991 Mar; 266(9): 5625-5628.

[71] Fosang AJ, Last K, Maciewicz RA. Aggrecan is degraded by matrix metalloproteinases in human arthritis. J. Clin. Invest. 1996 Nov; 98(10): 2292-2299. Doi: 10.1172/JCI119040.

[72] Murphy G, Lee M. What are the roles of metalloproteinases in cartilage and bone damage. Ann. Rheum. Dis. 2005 Nov; 64(4): 44-47. Doi: 10.1136/ard.2005.042465.

[73] Leivonen SK, Lazaridis K, Decock J, Chantry A, Edwards DR, Kahari VM. TGF-B-elicited induction of tissue inhibitor of metalloproteinases (TIMP)-3 expression in fibroblasts involves complex interplay between smad3, p38a, and ERK1/2. PLoS One. 2013 Feb; 8(2): 574-578. Doi: 10.1371/journal.pone.0057474.

[74] Qureshi HY, Sylvester J, El Mabrouk M, Zafarullah M. TGF-beta-induced expression of tissue inhibitor of metalloproteinase-3 gene in chondrocytes is mediated by extracellular signal-regulated kinase pathway and Sp1 transcription factor. J. Cell Physiol. 2005 May; 203(2): 345-352. Doi: 10.1002/jcp.20228.

[75] Troeberg L, Nagase H. Proteases involved in cartilage matrix degradation in osteoarthritis. Biochim. Biophys. Acta. 2012 Jan; 1824(1): 133-145. Doi: 10.1016/j.bbapap.2011.06.020. 
[76] Radin EL, Rose RM. Role of subchondral bone in the initiation and progression of cartilage damage. Clin. Orthop. Relat. Res. 1986 Dec; 213(12): 34-40.

[77] Zhang Y, Pizzute T, Pei M. Anti-inflammatory strategies in cartilage repair. Tissue Eng. Rev. 2014 Dec; 20(6): 655-668. Doi: 10.1089/ten.teb.2014.0014.

[78] Van der Kraan PM, van den Berg WB. Osteophytes: relevance and biology. Osteoarthritis Cartilage. 2007 Mar; 15(3): 237-244. Doi: 10.1016/j.joca.2006.11.006.

[79] Morscher E. Cartilage-bone lesions of the knee joint following injury. Reconstr. Surg. Traumatol. 1971 Oct; 12(10): 2-26.

[80] Falah M, Nierenberg G, Soudry M, Hayden M, Volpin G. Treatment of articular cartilage legions of the knee. Int. Orthop. 2010 Jun; 34(5): 621-630. Doi: 10.1007/s00264-010-0959-y.

[81] Guilak F, Ratcliffe A, Lane N, Rosenwasser MP, Mow VC. Mechanical and biochemical changes in the superficial zone of articular cartilage in canine experimental osteoarthritis. J. Orthop. Res. 1994 Jul; 12(4): 474484. Doi: 10.1002/jor.1100120404.

[82] Moskowitz RW. The biochemistry of osteoarthritis. Rheumatol. 1984 Aug; 23(3): 170-172. Doi: 10.1093/rheumatology/23.3.170.

[83] Livshits G, Ermakov S, Vilker A. Outlines of the biochemistry of osteoarthritis. Curr. Rheumatol. Rev. 2010 Aug; 6(4): 234-250.

[84] Tehranzadeh J, Booya F, Root J. Cartilage metabolism in osteoarthritis and the influence of viscosupplementation and steroids: a review. Acta. Radiol. 2005 May; 46(4): 288-296.

[85] Chadha R. Revealed aspect of metabolic osteoarthritis. J. Orthop. 2016 Dec; 13(4): 347-351. Doi: 10.1016/jor.2016.06.029.

[86] Mobasheri A, Rayman MP, Gualilo O, Sellam J, van der Kraan P, Fearon U. The role of metabolism in the pathogenesis of osteoarthritis. Nat. Rev. Rheumatol. 2017 May; 13(5): 302-311. Doi: 10.1038/nrrheum.2017.050.

[87] Vinatier C, Guicheux J. Cartilage tissue engineering: from biomaterials and stem cells to osteoarthritis treatments. Ann. Phys. Rehab. Med. 2016 Jun; 59(3): 139-144. Doi: 10.1016/j.rehab.2016.03.002.

[88] Phull AR, Eo SH, Abbas Q, Ahmed M, Kim SJ. Applications of chondrocyte based cartilage engineering: an overview. Biomed. Res. Int. 2016 Aug; 20(8): 1837-1870. Doi: 10.1155/2016/1879837.

[89] Zhang L, Hu J, Kyriacos AA. The role of tissue engineering in articular cartilage repair and regeneration. Crit. Rev. Biomed. Eng. 2009 Feb; 37(2): 1-57.

[90] Liu Y, Zhou G, Cao Y. Recent Progress in Cartilage Tissue Engineering. Eng. 2017 Feb; 3(1): 28-35. Doi: 10.1016/J.ENG.2017.01.010.

[91] Baluska F, Volkmann D, Barlow PW. Eukaryotic cells and their cell bodies: cell theory revised. Ann. Bot. 2004 Jul; 94(1): 9-32. Doi: 10.1093/aob/mch109. 
[92] Gugjoo MB, Amarpal A, Sharma GT, Aithal HP, Kinjavdekar P. Cartilage tissue engineering: role of mesenchymal stem cells along with growth factors and scaffolds. Indian J. Med. Res. 2016 Sep; 144(3): 339-347. Doi: 10.4103/0971-5916.198724.

[93] Somoza RA, Welter JF, Correa D, Caplan AI. Chondrogenic differentiation of mesenchymal stem cells: challenges and unfulfilled expectations. Tissue Eng. Rev. 2014 Dec; 20(6): 596-608. Doi: 10.1089/ten.teb.2013.0771.

[94] Solchaga LA, Penick KJ, Welter JF. Chondrogenic differentiation of bone marrow-derived mesenchymal stem cells. Methods Mol. Biol. 2011 Jun; 698(2): 253-278. Doi: 10.1007/978-1-60761-999-4_20.

[95] Mobasheri A, Kalamegam G, Musumeci G, Batt ME. Chondrocyte and mesenchymal stem cell-based therapies for cartilage in osteoarthritis and related orthopaedic conditions. Maturitas. 2014 Jul; 78(3): 188-198. Doi:

10.1016/j. maturitas.2014.04.017.

[96] O’Brien FJ. Biomaterials and scaffolds for tissue engineering. Mat. Tod. 2011 Mar; 14(3): 88-95. Doi: 10.1016/S1369-7021(11)70058-X

[97] Chan BP, Leong KW. Scaffolding in tissue engineering: general approaches and tissue-specific considerations. Eur. Spine J. 2008 Dec; 17(4): 10.1007/s00586-008-0745-3

[98] Moutos FT, Guilak F. Composite scaffolds for cartilage tissue engineering. Biorheology. 2008 Aug; 45(4): 501-512.

[99] Nicodemus GD, Bryant SJ. Cell encapsulation in biodegradable hydrogels for tissue engineering applications. Tissue Eng. Rev. 2008 Jun; 14(2): 149-165. Doi: 10.1089/ten.teb.2007.0332.

[100] Hillel A, Shah P, Elisseeff J. Hydrogels in cell encapsulation and tissue engineering. Biomed. Pol. 2007 Dec; 289(12): 57-82. Doi: 10.1533/9781845693640.57

[101] Drury JL, Mooney DJ. Hydrogels for tissue engineering: scaffold design variables and applications.

Biomaterials. 2003 Nov; 24(24): 4337-4351. Doi: 10.1016/S0142-9612(03)00340-5.

[102] El-Sherbiny IM, Yacoub MH. Hydrogel scaffolds for tissue engineering: progress and challenges. Glob. Cardiol. Sci. Pract. 2013 Nov; 20(3): 316-342. Doi: 10.5339/gcsp.2013.38.

[103] Gasperini L, Mano JF, Reis RL. Natural polymers for the microencapsulation of cells. J. R. Soc. Interface. 2014 Nov; 100(11): 817-824. Doi: 10.1089/rsif.2014.0817.

[104] Arnott A, Fulmer A, Scott WE, Dea IC, Moorhouse R, Rees DA. The agarose double helix and its function in agarose gel structure. J. Mol. Biol. 1974 Dec; 90(2): 269-272. Doi: 10.1016/0022-2836(74)90372-6.

[105] Lee PY, Costumbrado J, Hsu CY, Kim YH. Agarose gel electrophoresis for the separation of DNA fragments. J. Vis. Exp. 2012 Apr; 62(4): 3923-2931. Doi: 10.3791/3923.

[106] Kaupp JA, Weber JF, Waldman SD. Mechanical stimulation of chondrocyte-agarose hydrogels. J. Vis. Exp. 2012 Oct; 68(5): 4229-4234. Doi: 10.3791/4229

[107] DiMicco MA, Kisiday JD, Gong H, Grodzinsky AJ. Structure of pericellular matrix around agarose-embedded chondrocytes. Osteoarthritis Cartilage. 2007 Oct; 15(10): 1207-1216. 
[108] Buschmann MD, Gluzband YA, Grodzinsky AJ, Kimura JH, Hunziker EB. Chondrocytes in agarose culture synthesize a mechanically functional extracellular matrix. J Orthop Res. 1992 Nov; 10(6): 745-758. Doi:

10.1002/jor.1100100602.

[109] Lee KY, Mooney DJ. Alginate: properties and biomedical applications. Prog. Polym. Sci. 2012 Jan; 37(1): 106-126. Doi: 10.1016/progpolymsci.2011.06.003.

[110] Aarstad OA, Tondervik A, Sletta H, Skjak-Braek G. Alginate sequencing: an analysis of block distribution in alginates using specific alginate degrading enzymes. Biomacromolecules. 2012 Jan; 13(1): 106-116. Doi:

$10.1021 / \mathrm{bm} 20123026$.

[111] Ghidoni I, Chlapanidas T, Bucco T, Crovato F, Marazzi M, Vigo D, Torre ML, Faustini M. Alginate cell encapsulation: new advances in reproduction and cartilage regenerative medicine. Cytotechnology. 2008 Sep; 58(1): 49-56. Doi: 10.1007/s10616-008-9161-0.

[112] De Ceuninck F, Lesur C, Pastoureau P, Caliez A, Sabatini M. Culture of chondrocytes in alginate beads. Methods Mol. Biol. 2004 Feb; 100(2): 15-22. Doi: 10.1385/1-59259-810-2:015.

[113] Aydelotte MB, Thonar EJ, Mollenhauer J, Flechtenmacher J. Culture of chondrocytes in alginate gel. In Vitro Cell Dev. Biol. Anim. 1998 Feb; 34(2): 123-130. Doi: 10.1007/s11626-998-0094-x.

[114] Mhanna R, Kashyap A, Palazzolo G, Zenobi-Wong M. Chondrocyte culture in three dimensional alginate sulfate hydrogels promotes proliferation while maintaining expression of chondrogenic markers. Tissue Eng. 2014 May; 20(9): 1454-1464. Doi: 10.1089/ten.tea.2013.0544.

[115] Xu X, Jha AK, Harrington DA, Farach-Carson MC, Jia X. Hyaluronic acid-based hydrogels: from a natural polysaccharide to complex networks. Soft Matter. 2012 Mar; 8(12): 3280-3294. Doi: 10.1039/C2SM06463D.

[116] Vazquez-Portalati NN, Kilmer CE, Panitch A, Liu JC. Characterization of collagen type I and II blended hydrogels for articular cartilage tissue engineering. Biomacromolecules. 2016 Oct; 17(10): 3145-3152. Doi: 10.1021/acs.biomac.6b00684.

[117] Calderon L, Collin E, Velasco-Bayon D, Murphy M, O'Halloran D, Pandit A. Type II collagen-hyaluron hydrogel: a step towards a scaffold for intervertebral disc tissue engineering. Eur. Cells Mat. 2010 Sep; 20(9): 134148. Doi: 10.22203/ecm.v020a12.

[118] Antoine EE, Vlachos PP, Rylander MN. Review of collagen I hydrogels for bioengineered tissue microenvironments: characterization of mechanics, structure, and transport. Tissue Eng. Rev. 2014 Dec; 20(6): 683696. 10.1089/ten.teb.2014.0086.

[119] Kwon H, Paschos NK, Hu JC, Athanasiou K. Articular cartilage tissue engineering: the role of signaling molecules. Cell Mol. Life Sci. 2016 Mar; 73(6): 1173-1194. Doi: 10.1007/s00018-015-2115-8.

[120] Guilak F. Biomechanical factors in osteoarthritis. Best Pract. Res. Clin. Rheumatol. 2011 Dec; 25(6): 815823. Doi: 10.1016/j.berh.2011.11.013

[121] Van Osch GJ, Mandl EW, Marjinissen WJ, van der Veen SW, Verwoerd-Verhoef HL, Verhaar JA. Growth factors in cartilage tissue engineering. Biorheology. 2002 Feb; 39(2): 215-220. 
[122] Pazzano D, Mercier KA, Moran JM, Fong SS, DiBiasio DD, Rulfs JX, Kohles SS, Bonassar LJ. Comparison of chondrogenesis in static and perfused bioreactor culture. Biotech. Prog. 2008 Sep; 16(5): 893-896. Doi: $10.1021 / \mathrm{bp} 000082 \mathrm{v}$.

[123] Dahlin RL, Meretoja VV, Ni M, Kasper FK, Mikos AG. Chondrogenic phenotype of articular chondrocytes in monoculture and co-culture with mesenchymal stem cells in flow perfusion.

[124] Patti AM, Gabriele A, Rocca CD. Human chondrocyte cell lines from articular cartilage of metatarsal phalangeal joints. Tiss. Cell. 1999 Dec; 31(6): 550-554. Doi: 10.1054/tice.1999.0069.

[125] Ronot X, Sene C, Boschetti E, Hartmann DJ, Adolphe M. Culture of chondrocytes in medium supplemented with fetal calf serum or a serum substitute. Biol. Cell. 1984 Mar; 51(3): 307-313. Doi: 10.1111/j.1768-

322X.1984.tb00309.x

[126] Schafer KA. The cell cycle: a review. Vet. Pathol. 1998 Nov; 35(6): 461-478. Doi:

$10.1177 / 03009858980350061$.

[127] Johnson DG, Walker CL. Cyclins and cell cycle checkpoints. Ann. Rev. Pharm. Toxicol. 1999 Apr; 39(1): 295-312. Doi: 10.1146/annurev.pharmtox.39.1.295.

[128] Malumbres M. Cyclin-dependent kinases. Genome Biol. 2014 Jun; 15(6): 122-148. Doi: 10.1186/gb4184.

[129] Bernard S, Herzel H. Why do cells cycle with a 24 hour period. Genome Inform. 2006 Jan; 17(1): 72-79.

[130] Wilsman NJ, Farnum CE, Green EM, Lieferman EM, Clayton MK. Cell cycle analysis of proliferative zone chondrocytes in growth plates elonging at different rates. J. Orthop. Res. 1996 Jul; 14(4): 562-572. Doi:

10.1002/jor.1100140410.

[131] Buschmann H, Green P, Sambade A, Doonan JH, Lloyd CW. Cytoskeletal dynamics in interphase, mitosis, and cytokinesis analysed through agrobacterium-mediated transient transformation of tobacco BY-2 cells. New Phytol. 1011 Apr; 190(1): 258-267. Doi: 10.1111/j.1469-8137.2010.03587.x.

[132] Hunt T, Nasmyth K, Novak B. The cell cycle. Philos. Trans. R. Soc. Lond. Biol. Sci. 2011 Dec; 366(1584): 3494-3497. Doi: 10.1098/rstb.2011.0274.

[133] Flemming W. Contributions to the knowledge of the cell and its vital processes. J. Cell Biol. 1965 Apr; 25(1): 3-69.

[134] Hartwell LH. Saccharomyces cerevisiae cell cycle. Bacteriol. Rev. 1974 Jun; 38(2): 164-198.

[135] Mazia D. Mitosis and the physiology of cell division. The Cell. 1961 Feb; 3(2): 77-112. Doi: 10.1016/B9780-12-123303-7.50008-9.

[136] Pollard TD. Mechanics of cytokinesis in eukaryotes. Curr. Opin. Cell Biol. 2010 Feb; 22(1): 50-56. Doi: 10.1016/j.ceb. 1009.11.010.

[137] Gavet O, Pines J. Activation of cyclin B1-Cdk1 synchronizes events in the nucleus and the cytoplasm at mitosis. J. Cell Biol. 2010 Apr; 189(2): 247-283. Doi: 10.1083/jcb.200909144. 
[138] Yakagama Y, Yamaguchi N. Role of cyclin B1 levels in DNA damage and DNA damage-induced senescence. Int. Rev. Cell Mol. Biol. 2013 Mar; 305(3): 303-337. Doi: 10.1016/B978-0-12-407695-2.00007-X.

[139] Baker R. Stages of the cell cycle- mitosis (metaphase, anaphase and telophase).Med. Sci. 2017 Feb; 324(2): 171-175.

[140] Walczak CE, Cai S, Khodjakov A. Mechanisms of chromosome behavior during mitosis. Nat. Rev. Mol. Cell Biol. 2010 Feb; 11(2): 91-102. Doi: 10.1038/nrm2832.

[141] Walczak CE, Heald R. Mechanisms of mitotic spindle assembly and function. Int. Rev. Cytol. 2008 Feb; 265(2): 111-158. Doi: 10.1016/S0074-7696(07)65003-7.

[142] Bavle RM. Mitosis at a glance. J. Oral. Maxillofac. Pathol. 2014 Sep; 18(1): 252-255. Doi: 10.4103/0973029X.141175.

[143] Pereira AJ, Maiato H. Maturation of the kinetochore-microtubule interface and the meaning of metaphase.

Chromosome Res. 2012 Jul; 20(5): 563-577. Doi: 10.1007/s10577-012-9298-8.

[144] Yuan K, O'Farrell PH. Cyclin B3 is a mitotic cyclin that promotes the metaphase-anaphase transition. Curr. Biol. 2015 Mar; 25(6): 811-816. Doi: 10.1016/j.cub.2015.01.053.

[145] Ashraf M, Godward MB. The nucleolus in telophase, interphase, and prophase. J. Cell Sci. 1980 Feb; 41(2): 321-329.

[146] Donjerkovic D, Scott DW. Regulation of the G1 phase of the mammalian cell cycle. Cell Res. 2000 Mar; 10(1): 1-16. Doi: 10.1038/sj.cr.7290031.

[147] Foster DA, Yellen P, XU L, Saqcena M. Regulation of G1 cell cycle progression: distinguishing the restriction point from a nutrient-sensing cell growth checkpoint. Genes Cancer. 2010 Nov; 1(11): 1124-1131. Doi:

$10.1177 / 194760190392989$.

[148] Dong P, Zhang C, Parker BT, You L, Mathey-Prevot B. Cyclin D/Cdk4/6 activity controls G1 length in mammalian cells. PLos One. 2018 Jan;13(1): e0185637. Doi: 10.1371/journal.pone.0185637.

[149] Kanie T, Onoyama I, Matsumoto A, Yamada M, Nakayama KI. Genetic reevaluation of the role of F-box proteins in cyclin D1 degradation. Mol. Cell Biol. 2012 Feb; 32(3): 590-605. Doi: 10.1128/MCB.06570-11

[150] Vermeulen K, Van Bosckstaele DR, Bereneman ZN. The cell cycle: a review of regulation, deregulation, and therapeutic targets in cancer. Cell Prolif. 2003 Jun; 36(3): 131-149.

[151] Takeda DY, Dutta A. DNA replication and progression through the S phase. Oncogene. 2005 Apr; 24(17): 2827-2843. Doi: 10.1038/sj.onc.1208616.

[152] Ganai RA, Johansson E. DNA replication: a matter of fidelity. Mol. Cell Rev. 2016 Jun; 62(5): 745-755. Doi: 10.1016/j.molcel.2016.05.003.

[153] Patel SS, Donmez I. Mechanisms of helicases. J. Biol. Chem. 2006 May; 281(5): 18265-18268. Doi: $10.1024 / j b c . R 600008200$. 
[154] Nasheuer HP, Smith R, Bauerschmidt C, Grosse F, Weisshart K. Initiation of eukaryotic DNA replication: regulation and mechanisms. Prog. Nucleic Acid Res. Mol. Biol. 2002 Aug; 72(8): 41-94.

[155] Alenzi FQ. Links between apoptosis, proliferation, and the cell cycle. Amer. Med. Tech. 2005 Apr; 292(3): 86-89.

[156] Kornberg A. Biological synthesis of deoxyribonucleic acid. Science. 1960 May; 131(3412): 1503-1508. Doi: 10.1126/science.131.3412.1503.

[157] Gong D, Ferrell JE. The roles of cyclin A2, B1, and B2 in early and late mitotic events. Mol. Cell Biol. 2010 Jul; 21(18): 3093-3277.

[158] Hartwell LH, Weinert TA. Checkpoints: controls that ensure the order of cell cycle events. Science. 1989 Nov; 246(4930): 629-634.

[159] Chow JP, Poon RY, Ma HT. Inhibitory phosphorylation of cyclin dependent kinase-1 as a compensatory mechanism for mitosis exit. Mol. Cell Biol. 2011 Apr; 31(7): 1478-1491. Doi: 10.1128/MCB.00891-10.

[160] Ducommon B, Cance J, Wright M. Regulation of tubulin synthesis during the cell cycle in the synchronous plasmodia of physarum polycephalum. J. Cell Physiol. 1990 Oct; 145(1): 120-128. Doi: 10.1002/jcp.1041450117.

[161] Ahn SH, Acurio A, Kron SJ. Regulation of the G2/M progression by the STE mitogen-activated protein kinase pathway in budding yeast filamentous growth. Mol. Cell Biol. 1999 Oct; 10(10): 3301-3316. Doi:

10.1091/mbc.10.10.3301.

[162] Salvador JM, Brown-Clay JD, Fornace AJ. Gadd45 in stress signaling, cell cycle control, and apoptosis. Adv. Exp. Med. Biol. 2013 Sep; 793(9): 1-19. Doi: 10.1007/978-1-4614-8289-5_1.

[163] Vairapandi M, Balliet AG, Hoffman B, Liebermann DA. Gadd45b and gadd45g are cdc2/cyclin B1 kinase inhibitors with a role in S and G2/M cell cycle checkpoints induced by genotoxic stress. J. Cell Physiol. 2002 Sep; 192(3): 327-338. Doi: 10.1002/jcp10140.

[164] Maeda T, Hanna AN, Sim AB, Chua PP, Chong MT, Tron VA. Gadd45 regulates G2/M arrest, DNA repair, and cell death in keratinocytes following ultraviolet exposure. J. Invest. Dermatol. 2002 Jul; 119(1): 22-26. Doi: 10.1046/j.1523-1747.2002.01781.x.

[165] Wang XW, Zhan Q, Coursen JD, Khan MA, Kontny HU, Yu L, Hollander MC, O'Connor PM, Fornace AJ, Harris CC. Gadd45 induction of a G2/M cell cycle checkpoint. Proc. Natl. Acad. Sci. USA. 1999 Mar; 96(7): 37063711 .

[166] Buttitta LA, Edgar BA. Mechanisms controlling cell cycle exit upon terminal differentiation. Curr. Opin. Cell Biol. 2007 Dec; 19(6): 697-704. Doi: 10.1016/jcb.2007.10.004.

[167] Cheung TH, Rando TA. Molecular regulation of stem cell quiescence. Nat. Rev. Mol. Cell Biol. 2013 Jun; 14(6): 3591-3617. Doi: 10.1038/nrm3591.

[168] Evans CH, Georgescu HI. Observations on the senescence of cells derived from articular cartilage. Mech. Ageing Dev. 1983 Jun; 22(2): 179-191. 
[169] Kusuzaki K, Sugimoto S, Takeshita H, Murata H, Hashiguchi S, Nozaki T, Emoto K, Ashihara T, Hirasawa Y. DNA cytofluorometric analysis of chondrocytes in human articular cartilages under normal or arthritic conditions.

Osteoarthritis Cartilage. 2001 Oct; 9(7): 664-670. Doi: 10.1053/joca.2001.0463.

[170] Wuelling M, Vortkamp A. Chondrocyte proliferation and differentiation. Endocr. Dev. 2011 Jul; 21(7): 1-11. Doi: 10.115900328081.

[171] Loeser RF. Aging and Osteoarthritis: the role of chondrocyte senescence and aging changes in the cartilage matrix. Osteoarthritis Cartilage. 2009 Aug; 17(8): 971-979. Doi: 10.1016/j.joca.2009.03.002.

[172] Giactini C, Giordano A. RB and cell cycle progression. Oncogene. 2006 Aug; 25(38): 5220-5227. Doi: 10.1038/sj.onc. 1209615.

[173] Karimian A, Ahmadi Y, Yousefi B. Multiple functions of p21 in cell cycle, apoptosis, and transcriptional regulation after DNA damage. DNA Repair (Amst.). 2016 Jun; 42(6): 63-71. Doi: 10.1016/j.dnerep.2016.04.008.

[174] Coqueret O. New roles for p21 and p27 cell cycle inhibitors: a function for each cell compartment. Trends Cell Biol. 2003 Feb; 13(2): 65-70.

[175] Shaw PH. The role of p53 in cell cycle regulation. Pathol. Res. Pract. 1996 Jul; 192(7): 669-675. Doi: 10.1016/S0344-0338(96)80088-4.

[176] Omura-Minamisawa M, Dicciani MB, Chang RC, Batova A, Bridgeman LJ, Schiff J, Cohn SL, London WB, $\mathrm{Yu}$ AL. P16/p14(ARF) cell cycle regulatory pathways in primary neuroblastoma: p16 expression is associated with advanced stage disease.

[177] White J, Dalton S. Cell cycle control of embryonic stem cells. Stem Cell Rev. 2005 Jun; 1(2): 131-138. Doi: 10.1385/SCR:1:2:131.

[178] Mantel C, Broxmeyer HE. Embryonic stem cells bypass numerous cell cycle checkpoints; not just G1. Blood. 2008 May; 112(57): 1331-13. Doi:

[179] Becker KA, Ghule PN, Therrien JA, Lian JB, Stein JL, van Wijnen AJ, Stein GS. Self-renewal of human embryonic stem cells is supported by a shortened G1 cell cycle phase. J. Cell Physiol. 2006 Dec; 209(3): 883-893. Doi: $10.1002 /$ jcp.20776.

[180] Yang J, Plikus MV, Komarova NL. The role of symmetric stem cell divisions in tissue homeostasis. PLoS. 2015 Dec; 11(12): e1004629. Doi: 10.1371/journal.pcbi.1004629.

[181] Banfalgi G. Overview of cell synchronization. Methods Mol. Biol. 2011 Jun; 761(6): 1-23. Doi: 10.1007/879$1-61779-182-6$ - 1 .

[182] Sonoda E. Synchronization of cells. Subcell Biochem. 2006 Mar; 40(3): 415-418.

[183] Merrill GF. Cell Synchronization. Methods Cell Biol. 1998 Aug; 57(8): 229-249.

[184] Krek W, DeCaprio JA. Cell synchronization. Methods Enzymol. 1995 Jul; 254(72): 114-124.

[185] Lin SZ, Li B, Lan G, Feng XQ. Activation and synchronization of the oscillatory morphodynamics in multicellular monolayer. PNAS. 2017 Jul; 114(31): 8157-8162. Doi: 10.1073/pnas.1705492114. 
[186] Barradas OP, Jandt U, Hass R, Kasper C, Sandig V, Portner R, Zeng AP. Physical methods for synchronization of a human production cell line. BMC Proc. 2011 Aug; 5(8): 49-51. Doi: 10.1186/1753-6561-5-S8P49.

[187] Jackman J, O'Connor PM. Methods for synchronizing cells at specific stages of the cell cycle. Curr. Prot. Cell Biol. 1998 Oct; 100(1): 8310-8320.

[188] Davis PK, Ho A, Dowdy SF. Biological methods for cell cycle synchronization of mammalian cells. BioTechniques. 2001 Jun; 30(6): 1322-1331.

[189] Koç A, Wheeler LJ, Mathews CK, Merrill GF. Hydroxyurea arrests DNA replication by a mechanism that preserves basal dNTP Pools. J. Biol. Chem. 2004 Jan; 279(1): 223-230. Doi: 10.1074/jbc.M303952200.

[190] Noy GP, Spadari S, Miller-Faures A, Miller AO, Kruppa J, Koch G. Synchronization of HeLa cell cultures by inhibition of DNA polymerase alpha with aphidicolin. Nucleic Acids Res. 1980 Jan; 8(2): 377-387.

[191] Ma HT, Poon RY. Synchronization of HeLa cells. Methods Mol. Biol. 2011 Jun; 761(32): 151-161. Doi: 10.1007/978-1-61779-182-6_10.

[192] Jha MN, Bamburg JR, Bedford JS. Cell cycle arrest by colcemid differs in normal and tumor cells. Cancer Res. 1994 Sep; 54(18): 5011-5015.

[193] Kamradi SJ, Keyomarsi K. Synchronization of the cell cycle using lovastatin. Cell Cycle. 2008 Aug; 7(15): 2434-2440. Doi: 10.4161/cc.6364.

[194] Nusse M, Egner HJ. Can nocodazole, an inhibitor of microtubule formation, be used to synchronize mammalian cells. Cell Tissue Kinet. 1984 Jan; 17(1): 13-23.

[195] De Barros FR, Goissis MD, Caetano HV, Paula-Lopes FF, Peres MA, Assumpçao ME, Visintin JA. Serum starvation and full confluency for cell cycle synchronization of domestic cat (felis catus) foetal fibroblasts. Reprod. Domest. Anim. 2010 Feb; 45(1): 38-41. Doi: 10.1111/j.1439-0531.2008.01201.x.

[196] Chen MF, Huang JJ, Yang XJ, Liu BQ, Zhang WZ, Huang L, Deng F, Ma J, Bai YJ, Lu R, Huang B, Gao QY, Zhuo YH, Ge J. Serum starvation induced cell cycle synchronization facilitates human somatic cells reprogramming. PLoS One. 2012 Apr; 7(4): e28203. Doi: 10.1371/journal.pone.0028203.

[197] Lloyd AC. The regulation of cell size. Cell Rev. 2013 Sep; 154(6): 1194-1205. Doi: 10.1016/j.cell.2013.08.053.

[198] Toprak SK, Dalva K, Çakar MK, Kursun N, Beksaç M. Flow cytometric evaluation of cell cycle regulators (cyclins and cyclin-dependent kinase inhibitors) expressed on bone marrow cells in patients with chronic myeloid leukemia and multiple myeloma. Turk. J. Haematol. 2012 Mar; 29(1): 17-27. Doi: 10.5505/tjh.2012.33602.

[199] Pozarowski Darzynkiewicz Z. Analysis of cell cycle by flow cytometry. Methods Mol. Biol. 2004 JAn; 281(1): 301-311.

[200] Nunez R. DNA measurement and cell cycle analysis by flow cytometry. Curr. Iss. Mol. Biol. 2001 Mar; 3(3): 67-70. Doi: 10.1385/1-59259-811-0:301. 
[201] Darzynkiewicz Z, Gong J, Juan G, Ardelt B, Traganos F. Cytometry of cyclin proteins. Cytometry. 1996 Sep; 25(1): 1-13. Doi: 10.1002/(SICI)1097-0320(19960901)25:1<1::AIDCYTO1>3.0.CO;2-N.

[202] Han YY, Gu Y, Zhang AC, Lo YH. Review: imaging techniques for flow cytometry. Lab Chip. 2016 Nov; 16(24): 4639-4647. Doi: 10.1039/c6lc01063f.

[203] Mahmood T, Yang PC. Western blot: technique, theory, and troubleshooting. N. Am. J. Med. Sci. 2012 Sep; 4(9): 429-434. Doi: 10.4103/1947-2714.100998.

[204] Lewis CW, Taylor RG, Kubara PM, Marshall K, Meijer L, Golstein RM. A western blot assay to measure cyclin dependent kinase activity in cells or in vitro without the use of radioisotopes. FEBS Let. 2013 Sep; 587(18): 3089-3095. Doi: 10.1016/j.febslet.2013.08.013.

[205] Frisa PS, Jacobberger JW. Cell cycle-related cyclin B1 quantification. PLoS One. 2009 Sep; 4(9): e7064. Doi: 10.1371/journal.pone0007064.

[206] Bass JJ, Wilkinson DJ, Rankin D, Phillips BE, Szewczyk NJ, Smith K, Atherton PJ. An overview of technical considerations for western blotting applications to physiological research. Scand. J. Med. Sci. Sports. 2017 Jan; 27(1): 4-25. Doi: 10.1111/sms.12702.

[207] Harper JV. Synchronization of Cell Populations in G1/S and G2/M phases of the cell cycle. Meth. Mol. Biol. 2005 Aug; 296(3): 157-166.

[208] Matherly LH, Schuetz JD, Westin E, Goldman IE. A method for the synchronization of cultured cells with aphidicolin. Anal. Biochem. 1989 Nov; 182(2): 338-345.

[209] Vassilev LT. Cell cycle synchronization at the G2/M phase border by reversible inhibition of CDK1. Cell Cycle. 2006 Nov; 5(22): 2555-2556. Doi: 10.4161/cc.5.22.3463.

[210] De Barros FR, Goissis MD, Caetano HV, Paula-Lopes FF, Peres MA, Assumpção ME, Visintin JA. Serum starvation and full confluency for cell cycle synchronization of domestic cat (felis catus) foetal fibroblasts. Reprod.

Domest. Anim. 2010 Feb; 45(1): 38-41. Doi: 10.1111/j.1439-0531.2008.01201.x.

[211] Strober W. Trypan Blue Exclusion Test of Viability. Curr. Protoc. Immunol. 2015 Nov; 111(30): B1-3. Doi: 10.1002/0471142735.ima03bs111.

[212] Crosby K, Simendinger J, Grange C, Ferrante M, Bernier T, Standen C. Immunohistochemistry Protocol for Paraffin-embedded Tissue Sections. Cell Sig. Tech. 2014 Apr; 22(2): 113-118.

[213] Poulos B, Sullivan, M. Quant-iT Pico Green dsDNA Assay. Protocols. 2015 Oct; 75(5): e1-e3. Doi: 10.17504/protocols.io/c5zy75.

[214] Etherington DJ, Sims TJ. Detection and Estimation of Collagen. J. Sci. Food. Agric. 1981 Jan; 32(1): 539546.

[215] Coulson-Thomas, VJ, Gesteira TF. Dimethylmethylene Blue Assay (DMMB). Bio. Prot. 2014 Sep; 4(18): e1236-e1238. Doi: 10.21769/BioProtoc.1236.

[216] Galavazi G, Schenk H, Bootsma D. Synchronization of mammalian cells in vitro by inhibition of the DNA synthesis. Exp. Cell. Res. 1966 Feb; 41(2): 428-437. Doi: 10.1016/S0014-4827(66)80149-0 
[217] Langan TJ, Chou RC. Synchronization of mammalian cell cultures by serum depravation. Methods Mol. Biol. 2011 Aug; 761(8): 75-83. Doi: 10.1007/978-1-61779-182-6_5

[218] Jortikka MO, Parkkinen JJ, Inkinen RI, Karner J, Jarvelainen HT, Nelimarkka LO, Tammi MI, Lammi MJ. The role of microtubules in the regulation of proteoglycan synthesis in chondrocytes under hydrostatic pressure.

Arch. Biochem. Biophys. 2000 Feb; 374(2): 172-180.

[219] Beswick RW, Ambrose HE, Wagner SD. Nocodazole, a microtubule de-polymerizing agent, induces apoptosis of chronic lymphocytic leukaemia cells associated with changes in Bcl2 phosphorylation and expression.

Leuk. Res. 2006 Apr; 30(4): 427-436. Doi: 10.1016/j.leukres.2005.08.009.

[220] Cigan SD, Roach BL, Nims RJ, Tan AR, Albro MB, Stoker AM, Cook JL, Vunjak-Novakovic G, Hung CT, Ateshian GA. High seeding density of human chondrocytes in agarose produces tissue-engineered cartilage approaching native mechanical and biomechanical properties. J. Biomech. 2016 Jun; 49(9): 1909:1917. Doi: 10.1016/jbiomech.2016.04.039.

[221] De Ceuninck F, Lesur C, Pastoreau P, Caliez A, Sabatini M. Culture of Chondrocytes in Alginate Beads. Methods Mol. Med. 2004 Mar;100(3): 15-22. Doi: 10.1385/1-59259-810-2:015.

[222] Brand JA, McAlindon TE, Zeng L. A 3D system for culturing human articular chondrocytes in synovial fluid. J. Vis. Exp. 2012 Jan; 59(1) 3587-3596. Doi: 10.3791/3587

[223] Kusuzaki K, Sugimoto S, Takeshita H, Murata H, Hashiguchi S, Nozaki T, Emoto K, Ashihara T, Hirasawa Y. DNA cytofluorometric analysis of chondrocytes in human articular cartilages under normal, aging, or arthritic conditions. Osteoarthritis Cartilage. 2001 Oct; 9(7): 664-670. Doi: 10.1053/joca.2001.0463.

[224] Kwon DJ et. al. Effects of Cell Cycle Regulators on the Cell Cycle Synchronization of Porcine induced Pluripotent Stem Cells. Dev. Reprod. 2017 Mar; 21(1): 47-54. Doi: 10.12717/DR.2017.21.1.047

[225] Veer-Reddy GP et. al. Cell Cycle Analysis of Pluripotent Hematopoietic Progenitor Stem Cells. Blood. 1997: Vol 90- 2293-2299.

[226] Laranjeiro R et. al. Circadian Clock synchronization of the Cell Cycle in Zebrafish Occurs through a Gating Mechanism Rather than a Period-phase locking process. J Biol Rhythms. 2018 Apr; 33(2)- 137-150. Doi: $10.1177 / 0748730418755583$

[227] Gordon RE, Lane, BP. Duration of Cell Cycle and its Phases Measured in Synchronized Cells of Squamous Cell Carcinoma of Rat Trachea. Cancer Research. 1980 Dec; 40(12): 4467-4472. Doi: 0008-5472/80/0040$0000 \$ 02.00$

[228] Bruder SP, Jaiswal N, and Haynesworth SE. Growth kinetics, self-renewal, and the osteogenic potential of purified human mesenchymal stem cells during extensive subcultivation and following cryopreservation. J. Cell Biochem. 1997 Feb; 64(2): 278-294. Doi: 10.1002/(SICI)1097-4644(199702)64:2<278::AID-JCB11>3.0.CO;2-F

[229] Somal A et. al. A comparative study of Growth Kinetics, In Vitro Differentiation Potential and Molecular Characterization of Fetal Adnexa derived Caprine Mesenchymal Stem Cells. PLoS One. 2016; 11(6): e0156821. Doi: 10.1371 /journal.pone.0156821

[230] McKee C, Chaudhry GR. Advances and Challenges in Stem Cell Culture. Colloids and Surfaces B: Biointerfaces. 2017 Nov; 159(1): 62-77. Doi: 10.1016/j.colsurfb.2017.07.051 
[231] Hanley PJ, Mei Z, da Graca Cabreira-Hansen M, Klis M, Li W, Zhao Y. Manufacturing mesenchymal stromal cells for phase I clinical trials. Cytotherapy. 2013 Apr; 15(4): 416-422. Doi: 10.1016/j.jcyt.2012.09.007

[232] D. Schop, FW, Janssen, E, Borgart, JD, de Bruijn, R, van Dijkhuizen, R. Expansion of mesenchymal stem cells using a microcarrier-based cultivation system: growth and metabolism. J. Tissue Eng. Regen. Med. 2008 Mar; 2(3): 126-135. Doi: 10.1002/term.73

[233] Fedarko, NS and Shapiro, JR. Cell proliferation of human fibroblasts and osteoblasts in Osteogenesis imperfecta: influence of age. JBMR. 1995 Nov: 10(11): 1705-1712. Doi: 10.1002/jbmr.5650101113

[234] Chen C. and Chen SC. 1981. Cell growth factor activity: New quantitative method in cell culture assay. Experimental Cell Research. 1981 Nov; 136(1): 43-51. Doi: 10.1016/0014-4827(81)90036-7

[235] Silva ALC and Horta ACG. Growth Characteristics and Dynamics of Protein Synthesis in Callus Cultures from Glycine wightii. Cienc. Agrotec. 2005 Dec; 29(6): 1161-1166. Doi: 10.1590/S1413-70542005000600009

[236] Delise AM, Fischer L, Tuan RS. Cellular Interactions and Signaling in Cartilage Development. Osteoarthritis and Cartilage. 2000 Sep; 8(5): 309-334. Doi: 10.1053/joca.1999.0306

[237] Pardee AB. A restriction point for control of normal animal cell proliferation. Proc. Natl. Acad. Sci. U.S.A. 1974 Apr; 71(4): 1286-1290.

[238] Zetterberg A, Larsson O, and Wiman KG. What is the restriction point. Curr. Opin. Cell Biol. 1995 Dec; 7(6): $835-842$.

[239] Chen CC and Lau LF. Functions and Mechanisms of Action of CCN Matricellular Proteins. Int. J. Biochem. Cell Biol. 2009 Apr; 41(4): 771783. Doi: 10.1016/j.biocel.2008.07.025

[240] Istvanffy R et. al. Stroma-derived Connective Tissue Growth Factor Maintains Cell Cycle Progression and Repopulation Activity of Hematopoietic Stem Cells In Vitro. Stem Cell Reports. 2015 Nov; 5(5): 702-715. Doi: 10.1016/j.stemcr.2015.09.018

[241] AbdelWahab N, Weston BS, Roberts T, Mason RM. Connective Tissue Growth Factor and regulation of the mesangial cell cycle: role in cellular hypertrophy. J. Am. Soc. Nephrol. 2002 Oct; 13(10): 2437-2445. Doi: 10.1097/-1.ASN.0000031828.58276.02

[242] Aoyama E, et. al. N-terminal domains of $\mathrm{CCN}$ family 2/connective tissue growth factor bind to aggrecan. Biochem. J. 2009 May; 420(3): 413-420. Doi: 10.1042/BJ20081991

[243] Oh CD et. al. Sox9 Directly Regulates CTGF/CCN2 Transcription in Growth Plate Chondrocytes and in Nucleus Pulposus Cells of Intervertebral Disc. Sci. Rep. 2016 Jul; 6(1): 299-316. Doi: 10.1038/srep29916

[244] Lui Z, Lavine KJ, Hung IH, Ornitz DM. FGF18 is required for early chondrocyte proliferation, hypertrophy, and vascular invasion of the growth plate. Dev. Biol. 2007 Feb; 302(1): 80-91. Doi: 10.1016/j.ydbio.2006.08.071.

[245] Moore EE, Bendele AM, Thompson DL, Littau A, Waggie KS, Reardon B, Ellsworth JL. Fibroblast Growth Factor-18 stimulates chondrogenesis and cartilage repair in a rat model of injury induced osteoarthritis.

Osteoarthritis Cartilage. 2005 Jul; 13(7): 623-631. Doi: 10.1016/j.joca.2005.03.003. 
[246] Hill DJ, Logan A. Cell Cycle-Dependent Localization of Immunoreactive Basic Fibroblast Growth Factor to Cytoplasm and Nucleus of Isolated Ovine Fetal Growth Plate Chondrocytes. Growth Factors. 1992 Apr; 7(3): 215231. Doi: $10.3109 / 08977199209046926$.

[247] Olney RC, et. al. Chondrocytes from Osteoarthritic Cartilage have increased expression of insulin-like growth factor I (IGF-I) and IGF-binding protein-3 (IGFBP-3) and -5, but not IGF-II or IGFBP-4. JCEM. 1996 Mar; 81(3): 1096-1103. Doi: 10.1210/jcem.81.3.8772582

[248] Yakar S, Werner H, Rosen CJ. Insulin-like Growth Factors: actions on the skeleton. J. Mol. Endocrinol. 2018 Apr; 61(1): 115-137. Doi: 10.1530/JME-17-0298

[249] Serrat MA, Ion G. Imaging IGF-I uptake in growth plate cartilage using in vivo multiphoton microscopy. J. Appl. Physiol. 2017 Nov; 123(5): 1101-1109. Doi: 10.1152/japplphysiol.00645.2017

[250] Torres-Aleman, I. Toward a comprehensive neurobiology of IGF-I. Dev. Neurobiol. 2010 Apr; 70(5): 384396. Doi: 10.1002/dneu.20778

[251] Madry H, Kaul G, Cucchiarini M, Stein U, Zurakowski D, Remberger K, Menger MD, Kohn D, and Trippel SB. Enhanced repair of articular cartilage defects in vivo by transplanted chondrocytes overexpressing insulin-like growth factor-I (IGF-I). Gene Ther. 2005 Aug; 12(15): 1171-1179. Doi: 10.1038/sj.gt.3302515

[252] Chakravarthy MV, Abraha TW, Shwartz RJ, Fiorotto ML, Booth FW. Insulin-like growth factor-I extends in vitro replicative life span of skeletal muscle satellite cells by enhancing G1/S cell cycle progression via the activation of phosphatidylinol 3'-kinase/Akt signaling pathway. J. Biol. Chem. 2000 Nov; 275(46): 35942-35954. Doi: $10.1074 /$ jbc.M005832200

[253] Ren M, Zhong X, Chun-yan M, Sun Y, Guan Q, Cui B, Guo J, Wang H, Gao L, Zhao J. Insulin-like growth factor-1 promotes cell cycle progression via upregulation of cyclin D1 expression through the phosphatidylinositol 3-kinase/nuclear kB signaling pathway in FRTL thyroid cells. Acta Pharmologica Sinica. 2009 Jan; 30(1): 113 119. Doi: $10.1038 /$ aps.2008.8

[254] Alessandrini A, Chiaur DS, Pagano M. Regulation of the cyclin-dependent kinase inhibitor p27 by degradation and phosphorylation. Leukemia. 1997 Mar; 11(3): 342-345.

[255] Renato BASERGA. IGF-I Receptor and Gene Expression During the Cell Cycle. Cell Biol. And Biotech. Conference Paper. PP1-10. Doi: 10.1007/978-1-4684-9418-1_1

[256] Schmidt MB, Chen EH, Lynch SE. A review of the effects of insulin-like growth factor and platelet derived growth factor on in vivo cartilage healing and repair. Osteoarthritis Cartilage. 2006 May; 14(5): 403-412. Doi: 10.1016/j.joca.2005.10.011

[257] Hoch RV, Soriano P. Roles of PDGF in animal development. Development. 2003 Oct; 130(20): 4769-4784. Doi: $10.1242 /$ dev.00721

[258] Yu J, Liu XW, Hyeong-Reh CK. Platelet-derived growth factor (PDGF) Receptor-a-activated c-Jun NH2terminal Kinase-1 is Critical for PDGF-induced p21WAF1/CIP1 promoter activity independent of p53. J. Biol. Chem. 2003 Dec; 278(49): 49582-49588. Doi: 10.1074/jbc/M309986200 
[259] Manoranjan SJ, Faizuddin M, Hemalatha M, Ranganath V. The effect of platelet-derived growth factor-AB on periodontal ligament fibroblasts: an in vitro study. J. Indian Soc. Peridontol. 2012 Jan; 16(1): 49-53. Doi: 10.4103/0972-124X.94604.

[260] Pierce GF, Mustoe TA, Altrock BW, Deuel TF, Thomason A. "Role of platelet-derived growth factor in wound healing". J. Cell. Biochem. 1991 Apr; 45(4): 319-26. Doi: 10.1002/jcb.240450403

[261] Li TF, O’Keefe RJ, Chen D. TGF-B Signaling in Chondrocytes. Front. Biosci. 2005 Jan; 10(1): 681-688.

[262] Mukherjee P, Winter SL, Alexandrow MG. Cell Cycle Arrest by Transforming Growth Factor B1 near G1/S is mediated by acute abrogation of prereplication complex involving an Rb-MCM interaction. Mol. Cell. Biol. 2010 Feb; 30(3): 845-856. Doi: 10.1128/MCB.01152-09

[263] Iordanska T, Nawshad A. Mechanisms of Transforming Growth Factor B Induced Cell Cycle Arrest in Palate Development. J Cell Physiol. 2011 May; 226(5): 1415-1424. Doi: 10.1002/jcp.22477.

[264] Beier F, Ali Z, Taylor AC, Leask T, Albanese C, Pestell RG, Luvalle P. TGFbeta and PTHrP control chondrocyte proliferation by activating cyclin D1 expression. Mol. Biol. Cell. 2001 Dec; 12(12): 3852-3863. Doi: $10.1091 / \mathrm{mbc} .12 .12 .3852$

[265] Vivien D, Galera P, Lebrun E, Loyau G, Pujol JP. Differential effects of transforming growth factor-beta and epidermal growth factor on the cell cycle of cultured rabbit articular chondrocytes. J Cell. Physiol. 1990 Jun; 143(3): 534-545. Doi: 10.1002/jcp.1041430319.

[266] Vivien D, Redini F, Galera P, Lebrun E, Loyau G, Pujol JP. Rabbit articular chondrocytes (RAC) express distinct transforming growth factor-beta receptor phenotypes as a function of cell cycle. Exp. Cell. Res. 1993 Mar; 205(1): 165-170. Doi: 10.1006/excr.1993.1071

[267] Pateder DB, Rosier RN, Schwarz EM, Reynolds PR, Puzas JE, D’Souza M, O’Keefe RJ. PTHrP expression in chondrocytes, regulation by TGFbeta, and interactions between epiphyseal and growth plate chondrocytes. Exp.

Cell. Res. 2000 May; 256(2): 555-562. Doi: 10.1006/excr.2000.4860.

[268] Karlsen TA, Shahdadfar A, Brinchmann JE. Human primary articular chondrocytes, chondroblast-like cells, and de-differentiated chondrocytes: differences in gene, microRNA, and protein expression and phenotype. Tissue

Eng. Meth. 2011 Feb; 17(2): 219-227. Doi: 10.1089/ten.TEC/2010.0200. 